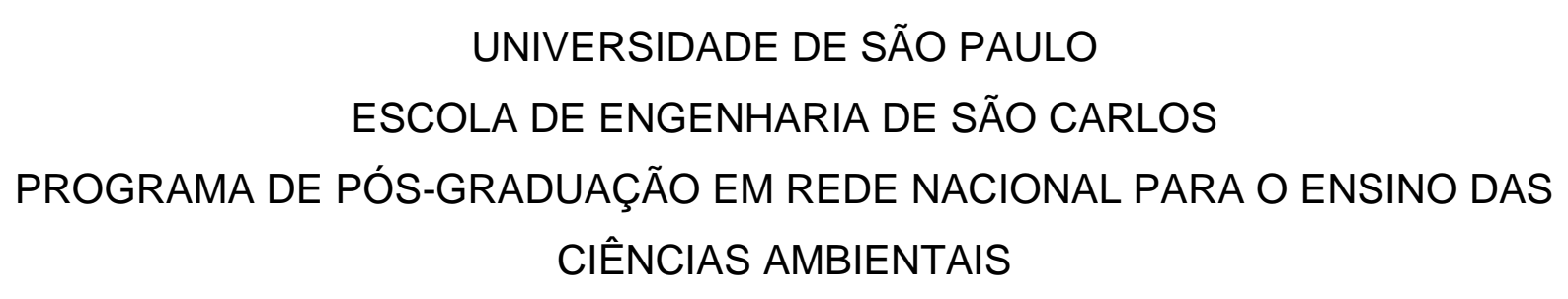

CARLA CRISTINA CASTANHEIRO DOS SANTOS

INCLUSÃO DA SUSTENTABILIDADE NO ESPAÇO ESCOLAR E COMUNIDADE: ALTERNATIVAS SUSTENTÁVEIS PARA OS ÓLEOS E GORDURAS RESIDUAIS DE FRITURA

SÃO CARLOS 


\title{
INCLUSÃO DA SUSTENTABILIDADE NO ESPAÇO ESCOLAR E COMUNIDADE: ALTERNATIVAS SUSTENTÁVEIS PARA OS ÓLEOS E GORDURAS RESIDUAIS DE FRITURA
}

\author{
Versão Corrigida \\ Dissertação apresentada como \\ requisito para obtenção do título de \\ Mestre em Ensino de Ciências \\ Ambientais ao Programa de Pós- \\ Graduação em Rede Nacional para \\ o Ensino de Ciências Ambientais da \\ Universidade de São Paulo.
}

Área de concentração: Ciências Ambientais - Projeto estruturante: Comunidade, Saúde e Ambiente.

Orientador: Prof. Dr. Tadeu Fabrício Malheiros 
AUTORIZO A REPRODUÇÃO E DIVULGAÇÃO TOTAL OU PARCIAL DESTE TRABALHO, POR QUALQUER MEIO CONVENCIONAL OU ELETRÔNICO, PARA FINS DE ESTUDO E PESQUISA, DESDE QUE CITADA A FONTE.

Ficha catalográfica elaborada pela Biblioteca Prof. Dr. Sérgio Rodrigues Fontes da EESC/USP

Santos, Carla Cristina Castanheiro dos
C237i Inclusão da sustentabilidade no espaço escolar e
comunidade / Carla Cristina Castanheiro dos Santos; orientador Tadeu Fabricio Malheiros. -- Säo Carlos, 2020.

Dissertação (Mestrado) - Programa de Pós-Graduação em Rede Nacional para o Ensino das Ciências Ambientais e Área de Concentração em Ensino das Ciências Ambientais -- Escola de Engenharia de São Carlos da Universidade de São Paulo, 2020 .

1. Residuos sólidos urbanos. 2. Oleos e gorduras residuais de fritura. 3. Sustentabilidade. 4. Ensino das ciências ambientais. 5. Sequência didática. I. Titulo. 


\section{FOLHA DE JULGAMENTO}

Candidata: Licenciado CARLA CRISTINA CASTANHEIRO DOS SANTOS.

Título da dissertação: "Inclusão da sustentabilidade no espaço escolar e comunidade: alternativas sustentáveis para os óleos e gorduras residuais de fritura ".

Data da defesa: 07/12/2020.

Comissão Julgadora

$\underline{\text { Resultado }}$

Prof. Associado Tadeu Fabricio Malheiros

$\triangle P R O V A D A$

\section{(Orientador)}

(Escola de Engenharia de São Carlos/EESC)

Profa. Dra. Alineaurea Florentino da Silva

(Universidade Federal de Pernambuco/UFPE)

Profa. Dra. Katia Viana Cavalcante

(Universidade Federal do Amazonas/UFAM)

Coordenador do Programa de Pós-Graduação em Rede Nacional para Ensino das Ciências Ambientais:

Prof. Associado Juliano José Corbi

Presidente da Comissão de Pós-Graduação:

Prof. Titular Murilo Araujo Romero 
Dedico esse trabalho à minha família: ao meu esposo Abner, pelo apoio e compreensão.

Às minhas maiores razões de lutar por um mundo melhor: meus amados filhos, Camily e Calil. À minha mãezinha Zilda, que nunca mediu esforços para que eu chegasse até aqui. 


\section{AGRADECIMENTOS}

Agradeço primeiramente a DEUS, pelo fôlego de vida e forças a mim concedidas para que eu pudesse realizar mais esse sonho.

A minha família: esposo e filhos, pela compreensão, apoio e ajuda em todos os momentos, mesmo quando parecia que eu não iria conseguir chegar até aqui eles estavam ali para me dar forças para prosseguir.

A minha mãezinha, que esteve ao meu lado durante toda a trajetória não medindo esforços para que esse sonho fosse possível.

Ao meu orientador, Professor Doutor Tadeu Fabrício Malheiros, que acreditou que eu seria capaz de desenvolver este trabalho e contribuir para uma educação integral junto à escola pública. Suas contribuições foram essenciais para o meu amadurecimento e para a realização deste trabalho.

A todos os professores do Programa PROFCIAMB por contribuírem para a minha formação durante todo o percurso, sendo essenciais para o meu crescimento intelectual.

O presente trabalho foi realizado com apoio da Coordenação de Aperfeiçoamento de Pessoal de Nível Superior (CAPES) e da Agência Nacional de Águas e Saneamento Básico (ANA).

A toda equipe da Escola Municipal Júlio Benedicto Mendes, por abrir as portas e acreditar que, por meio da educação, somos capazes de transformar o mundo.

Assim como dizia Paulo Freire, não existe educação sem amor. E, por amar a educação e acreditar na transformação das pessoas, não desisto de lutar todos os dias. 


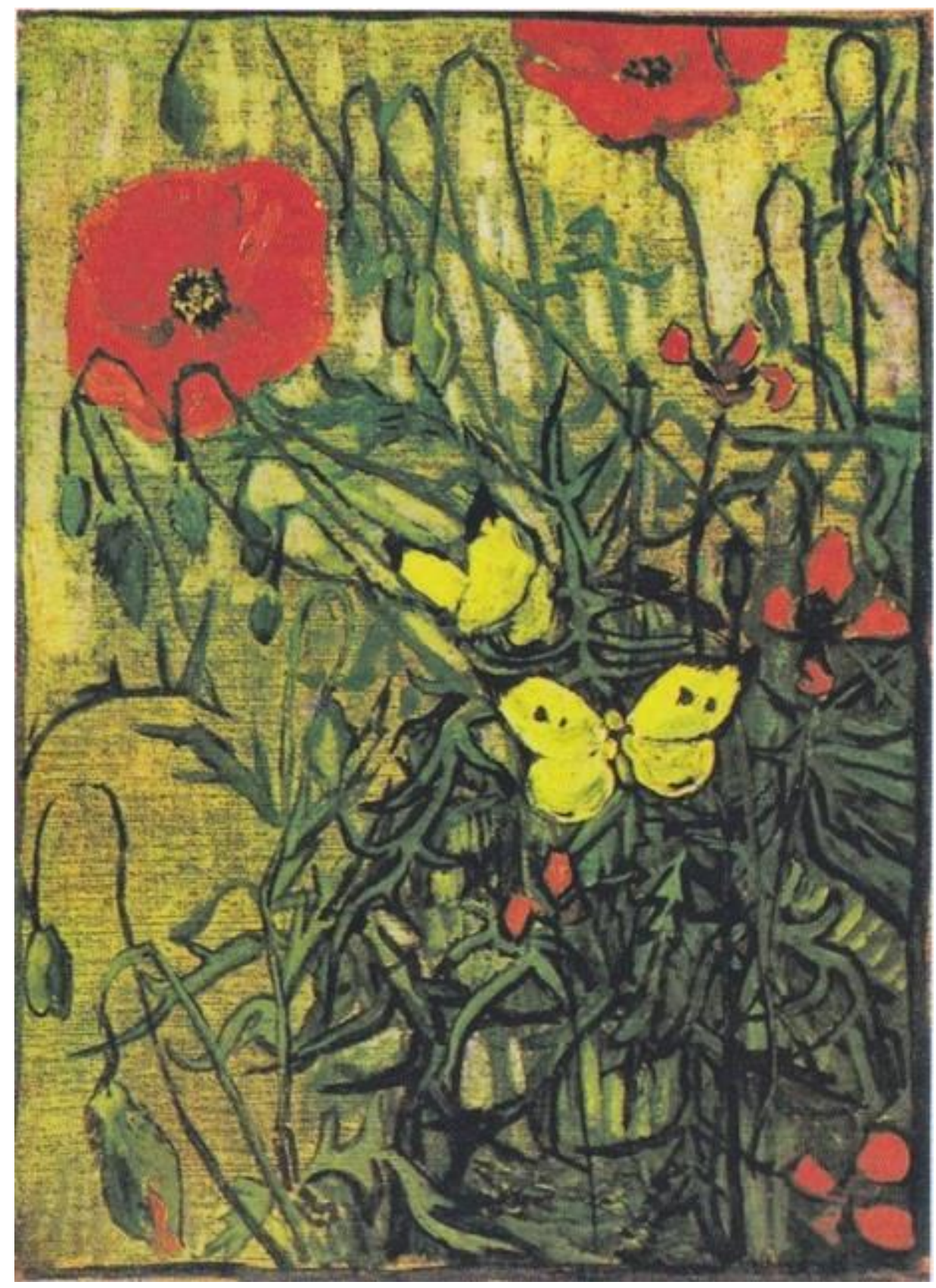

"Poppies and Butterflies" - 1890 - Vicent Van Gogh Museum, Amsterdam.

"Não haverá borboletas se a vida não passar por longas e silenciosas metamorfoses". 


\section{RESUMO}

SANTOS, Carla Cristina Castanheiro dos. Inclusão da sustentabilidade na escola e comunidade: Alternativas sustentáveis para os óleos e gorduras residuais de fritura. 2020. Dissertação (Mestrado em Ensino das Ciências Ambientais) - Escola de Engenharia de São Carlos, Universidade de São Paulo, São Carlos, 2020.

Os problemas de ordem ambiental são diversos e se agravam a cada dia. Dessa maneira, a escola enquanto espaço de formação e transformação tem como viabilizar a inserção do ensino das ciências ambientais para a sustentabilidade, a fim de trabalhar a sensibilização dos educandos e possibilitar a integração dos pais e/ou responsáveis e comunidade. Dentre os problemas ambientais estão os resíduos sólidos urbanos, em específico neste trabalho, os óleos e gorduras residuais de fritura que, hodiernamente, constituem-se como um dos maiores problemas ambientais. $\mathrm{O}$ descarte inadequado desses resíduos impacta significativamente os recursos hídricos, solo e ar. O objetivo desta pesquisa foi estudar, discutir e propor atividades para serem inseridas na sala de aula com o propósito de contribuir para a sensibilização de pessoas, fomentar atitudes sustentáveis e, consequentemente, minimizar os impactos ambientais provocados pelos óleos e gorduras residuais de fritura. A metodologia utilizada foi a pesquisa-ação, e para o embasamento teórico utilizou-se da revisão de literatura. Como instrumento de coleta de dados, foram utilizados questionário e entrevistas, analisados na abordagem qualitativa. O campo de pesquisa compreendeu uma turma de 21 alunos do $4^{\circ}$ ano, estudantes da escola municipal de ensino fundamental I Julio Benedicto Mendes, localizada no município de Ibaté, SP. A pesquisa foi desenvolvida no primeiro semestre do ano de 2019. Os resultados mostraram que a sequência didática, composta por atividades sistematizadas e interdisciplinares, contribui significativamente para o processo de sensibilização, construção da consciência ecológica do cidadão e minimização dos impactos ambientais por meio da reutilização e reciclagem dos óleos e gorduras residuais de fritura. Ainda, observou-se que a inserção dos pais e/ou responsáveis nos projetos de ensino das ciências ambientais favorece a aprendizagem, fortalece os vínculos e possibilita alcançar resultados mais efetivos em relação a alternativas sustentáveis. A partir da presente pesquisa, foi elaborada uma cartilha contendo uma sequência de atividades estruturadas com o propósito de subsidiar outros profissionais no ensino das ciências ambientais.

Palavras-chaves: Resíduos Sólidos Urbanos. Óleos e Gorduras Residuais de Fritura. Sustentabilidade. Ensino das Ciências Ambientais. Sequência Didática. 


\begin{abstract}
SANTOS, Carla Cristina Castanheiro dos. Inclusion of sustainability in school and community space: sustainable alternatives to residual frying oils and fats. 2020. Master's Dissertation (Master in Environmental Science Teaching) - School of Engineering of São Carlos, University of São Paulo, São Carlos, 2020.
\end{abstract}

The environmental problems are diverse and they are getting worse every day. Thus, the school as a space for training and changing, has the possibility of inserting the teaching of environmental sciences for sustainability, in order to raise the awareness of students and enable the integration of parents or guardians and the community. Among the environmental problems, there are urban solid residues, specifically in this work, residual frying oils and fats, which, nowadays, consist in one of the biggest environmental problems. Inadequate waste disposal has a major impact on water resources, soil and air. The aim of this research was to study, discuss and propose activities to be inserted in the classroom with the purpose of contributing to awareness of people, promoting sustainable attitudes and, consequently, minimizing the environmental impacts caused by residual frying oils and fats. The methodology used was action research, and for the theoretical basis, literature review was used. As a data collection instrument, questionnaires and interviews were used and analyzed using a qualitative approach. The research field consisted of a class with 21 4th grade students, class $\mathrm{C}$, from the municipal elementary school I Julio Benedicto Mendes, located in the city of lbaté, SP. The research was developed in the first semester of 2019. The results showed that the follow-up teaching, composed of systematized and interdisciplinary activities, contributes meaningly to the process of raising awareness, building the citizen's ecological awareness and minimizing environmental impacts through reuse and recycling of residual frying oils and fats. Besides, it was observed that the inclusion of parents or guardians in environmental science teaching projects supports learning, strengthens bonds and makes it possible to achieve more effective results in relation to sustainable alternatives. From this research, a booklet was prepared containing a sequence of activities that will help other professionals in the teaching of environmental sciences.

Keywords: Urban Solid Residues. Residual Frying Oils and Fats. Sustainability. Teaching Environmental Sciences. Following Teaching. 


\section{LISTA DE FIGURAS}

Figura 1 Estrutura BNCC -------------------------------------- 27

Figura 2 Fluxograma: etapas de desenvolvimento da pesquisa ----- 45

Figura 3 Galpão de reciclagem, triagem e separação dos materiais recicláveis e tambor coletor de OGRF 55

Figura 4 Sala de aula 4ํa ano - Apresentação do Tema ------------ 56

Figura 5 Entrega dos questionários -----on

Figura 6 Sala de vídeo - Filme: Um plano para salvar o planeta, de Maurício de Sousa ---

Figura 7 Poesia: A Terra com poluição ------------------------------ 59

Figura 8 Poesia: A poluição ---------- 59

Figura 9 Representação artística da música: Terra, Planeta Água,

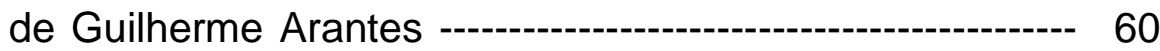

Figura 10 Workshop: Representação da música e dança

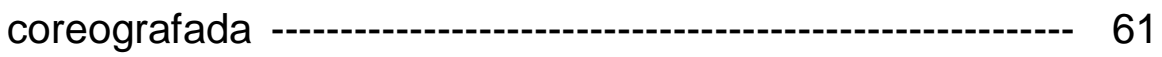

Figura 11 Observação de solo fértil ------- 62

Figura 12 Solo sendo poluído pelos OGRF - observação de impermeabilização --------------------------- 63

Figura 13 Origem dos óleos utilizados nos domicílios ---------------- 66

Figura 14 Consumo mensal de OGRF ---

Figura 15 Práticas mais utilizadas para descarte de OGRF ---------- 67

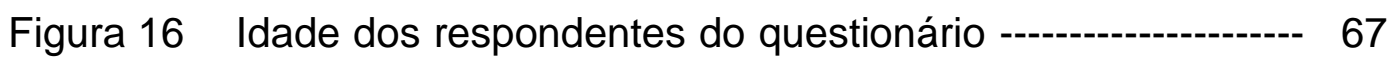

Figura 17 Workshop - Apresentação musical ------------------------ 70

Figura 18 Palestra - Resíduos Sólidos --- 71

Figura 19 Palestra - Resíduos Sólidos ------------------------ 72

Figura 20 Público da palestra ------------------------------------- 72

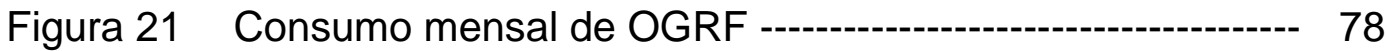




\section{LISTA DE SIGLAS E ABREVIATURAS}

ABNT - Associação Brasileira de Normas Técnicas

ABRELPE - Associação Brasileira de Empresas de Limpeza Pública e Resíduos Especiais

AEE - Atendimento Educacional Especializado

ANVISA - Agência Nacional de Vigilância Sanitária

BNCC - Base Nacional Comum Curricular

CAPES - Coordenação de Aperfeiçoamento de Pessoal de Nível Superior

CDHU - Companhia de Desenvolvimento Habitacional e Urbano do Estado de São

Paulo

CETESB - Companhia Ambiental do Estado de São Paulo

CF - Constituição Federal

CNE - Conselho Nacional de Educação

DCNs - Diretrizes Curriculares Nacionais

EA - Educação Ambiental

ECOLEO - Associação Brasileira para Sensibilização, Coleta e Reciclagem de

Resíduos de Óleo Comestível

EM - Escola Municipal

EPI - Equipamento de Proteção de Uso Individual

IBGE - Instituto Brasileiro de Geografia e Estatística

LDBEN - Lei de Diretrizes e Bases da Educação Nacional

MMA - Ministério do Meio Ambiente

MEC - Ministério da Educação

NR - Norma Regulamentadora

OCDE - Organização para Cooperação e Desenvolvimento Econômico

ODS - Objetivos do Desenvolvimento Sustentável

OGRF - Óleos e Gorduras Residuais de Fritura

ONU - Organização das Nações Unidas

UNESCO - Organização das Nações Unidas para Educação, Ciência e Cultura

PCNs - Parâmetros Curriculares Nacionais

PISA - Programa Internacional de Avaliação de Estudantes

PNEA - Política Nacional de Educação Ambiental 
PNRS - Política Nacional de Resíduos Sólidos

PNUMA - Programa das Nações Unidas para o Meio Ambiente SD - Sequência Didática

TCTs - Temas Contemporâneos Transversais 
CARTILHA EDUCATIVA: PRODUTO FINAL - APRESENTAÇÃO

A cartilha educativa, produto final desta pesquisa de mestrado profissional, contempla uma sequência de atividades estruturadas (sequência didática) elaborada para o ensino das ciências ambientais, em específico, os óleos e gorduras residuais de fritura (OGRF) que, se descartados de maneira inadequada, impactam significativamente nos recursos hídricos, solo e ar. Dessa maneira, o material aborda formas de descarte dos OGRF e alternativas sustentáveis.

As atividades foram desenvolvidas junto aos alunos do $4^{\circ}$ ano do ensino fundamental I da Escola Municipal Julio Benedicto Mendes, localizada no município de Ibaté, SP. Os conteúdos trabalhados fizeram parte do planejamento anual de ensino, integrando os componentes curriculares de Língua Portuguesa, Arte, Geografia e Matemática. Dessa maneira, as atividades foram desenvolvidas sob a luz da transversalidade e interdisciplinaridade, conforme orientações da Base Nacional Comum Curricular (BNCC, 2017).

A sequência didática, constante da cartilha, foi aplicada a alunos do ensino regular formal com o objetivo de sensibilizá-los para as questões de ordem ambiental. Porém, vale ressaltar que ela poderá ser utilizada também em instituições de ensino não formal, pois apresenta conteúdos relacionados à temática ambiental, fundamental à vida de todo ser humano, linguagem de fácil entendimento e recursos materiais disponíveis sem restrições.

A cartilha está disponível em formato digital de livre acesso, e em material impresso na instituição de ensino onde foi desenvolvido o projeto. Ela poderá ser utilizada por profissionais da educação ou outros envolvidos com o ensino que tenham interesse pela temática. 
1 INTRODUÇÃO -

1.1 JUSTIFICATIVA --- 17

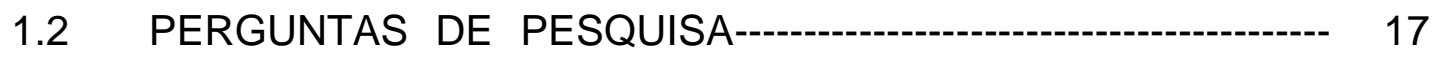

1.3 OBJETIVOS -- 18

1.3.1 Objetivo Geral --

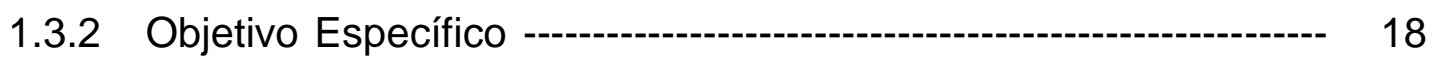

2 REVISÃO DA LITERATURA -

2.1 O ENSINO DAS CIÊNCIAS AMBIENTAIS E ABORDAGEM DA TEMÁTICA MEIO AMBIENTE -------- 19

2.2 HISTÓRICO DA EDUCAÇÃO AMBIENTAL - 20

2.3 LEGISLAÇÃO DA EDUCAÇÃO BRASILEIRA E A EDUCAÇÃO AMBIENTAL ----- 24

2.4 CORRENTES DE EDUCAÇÃO AMBIENTAL CONSERVACIONISTA E CRÍTICA -.-.-- 29

2.5 ELEMENTOS HISTÓRICOS E VERTENTES EDUCACIONAIS 31

2.6 ESCOLA, FAMÍLIA E COMUNIDADE -

2.7 ATIVIDADES SISTEMATIZADAS: SEQUÊNCIA DIDÁTICA ---- 34

2.8 RESÍDUOS SÓLIDOS: CONCEITO E CLASSIFICAÇÃO ------- 35

2.8.1 Aterro sanitário, aterro controlado e lixões: conceitos e Definições ---------- 37

2.8.2 Óleos e gorduras residuais de fritura: características e descarte 38

2.8.2.1 Ó Óleos e gorduras residuais de fritura: impactos ambientais provocados pelo descarte inadequado

2.8.2.2 Alternativas sustentáveis para os óleos e gorduras residuais de Fritura ------- 40

3 METODOLOGIA -

3.1 CARACTERIZAÇÃO DA PESQUISA --

3.2 CAMPO DE PESQUISA --- 49

$4 \quad$ RESULTADOS E DISCUSSÕES -

4.1 CONCEPÇÃO DA SEQUÊNCIA DIDÁTICA--- 51

4.2 VISITA AO GALPÃO DA RECICLAGEM DO MUNICÍPIO DE IBATÉ/SP 
4.3 DETALHAMENTO DAS ATIVIDADES TRABALHADAS DURANTE A APLICAÇÃO DO PROJETO --_- 55

5 CONSTRUÇÃO DO PRODUTO FINAL - CARTILHA 78 EDUCATIVA: Sequência didática para inclusão da sustentabilidade no espaço escolar: alternativas sustentáveis para os óleos e gorduras residuais de fritura-

6 CONSIDERAÇÕES FINAIS-

6.1 SUGESTÕES PARA FUTUROS TRABALHOS --

REFERÊNCIAS ---

APÊNDICE A: CARTILHA EDUCATIVA - SEQUÊNCIA DIDÁTICA PARA INCLUSÃO DA SUSTENTABILIDADE NO ESPAÇO ESCOLAR: ALTERNATIVAS SUSTENTÁVEIS PARA OS ÓLEOS E GORDURAS RESIDUAIS DE FRITURA - 92 APÊNDICE B: QUESTIONÁRIO PARA LEVANTAMENTO DE DADOS SOBRE O USO E DESCARTE DOS ÓLEOS RESIDUAIS DE FRITURA --- 126

ANEXO A - MÚSICA: PLANETA ÁGUA - 


\section{INTRODUÇÃO}

O meio ambiente ecologicamente equilibrado é direito fundamental de todos os cidadãos, da atual e das futuras gerações, assim como prevê o Art. 225 da Constituição Federal de 1988 (BRASIL, 1988). Mesmo este sendo um direito universal, o meio ambiente vem sofrendo alterações e degradações por meio de atividades antrópicas.

De acordo com a Norma Brasileira de Classificação dos Resíduos (ABNT NBR 10004: 2004), os resíduos sólidos, mais especificamente os óleos e gorduras residuais de fritura, têm se apresentado como um problema de ordem ambiental, trazendo inúmeras agressões ao meio ambiente e à saúde humana.

A esse respeito, Rosenhaim (2009) aponta que o descarte inadequado e os impactos provocados por esses resíduos, muitas vezes, são causados por ausência de informação e desconhecimento da população. Dessa maneira, para orientar e gerenciar esses resíduos, foi instituída a Política Nacional de Resíduos Sólidos (PNRS), a Lei n.12.305/2010.

Ainda de acordo com a PNRS, no capítulo III, Art. 8o, a Educação Ambiental (EA) constitui-se como um dos instrumentos de sensibilização e está inserida na área das Ciências Ambientais por seu caráter interdisciplinar e transversal, e, de acordo com a Lei n. 9.795/99, que institui a Política Nacional de Educação Ambiental (PNEA), a EA é um componente essencial e permanente da educação nacional, devendo estar presente em todos os níveis e modalidades de ensino.

Pode-se dizer que, por meio da educação, é possível transformar a consciência do indivíduo para que ele se sinta parte do mundo, da sociedade e atue criticamente como cidadão. Segundo Loureiro (2009, p.32):

\footnotetext{
Esse é um conceito central para entendermos a Educação Ambiental como um processo amplo e vinculado às esferas social, cultural, histórica, política e econômica; e para entendermos que ela sozinha não transforma o mundo, e que tampouco podemos imaginar transformações societárias sem que esta se realize.
}

Dessa maneira, o ensino das ciências ambientais para a formação integral e transformação do cidadão se concretiza quando a abordagem é contextualizada a 
partir das realidades global e local. Portanto, reitera-se a necessidade de se inserir práticas de ensino das ciências ambientais no âmbito escolar e comunidade, a fim de sensibilizar as pessoas para as questões ambientais.

Nesta pesquisa, foram utilizados os óleos e gorduras residuais de fritura (OGRF) para a sensibilização socioambiental por meio da reutilização, reciclagem, descarte adequado e uso de alternativas sustentáveis para esses resíduos.

Sensibilizar as pessoas para a transformação de sua própria realidade vai além dos muros da sala de aula, é preciso ação e mobilização. Nesse sentido, a inserção dos pais e/ou responsáveis e comunidade foram essenciais para a integralidade deste trabalho.

Após esta primeira seção, introdutória, na qual se apresentou o tema e os objetivos gerais e específicos desta pesquisa, a dissertação ficou organizada nas seguintes seções: revisão da literatura, metodologia, resultados e discussões, construção do produto final desta pesquisa, considerações finais e sugestões para trabalhos futuros.

A segunda seção fez a revisão da literatura e se subdividiu em ensino das ciências ambientais, trajetória da educação ambiental, legislação educacional e educação ambiental, com o intuito de compreender o desenvolvimento da educação ambiental desde as primeiras conferências, e como os documentos educacionais abordam os processos de ensino das ciências ambientais. Esta seção ainda discorreu sobre os elementos históricos da educação, vertentes educacionais, parceria entre escola, família e comunidade e sequência didática, que servem como subsídios à prática educativa. Os óleos e gorduras residuais de fritura, tema escolhido para inserção da sustentabilidade na escola, também foram descritos nas subdivisões da segunda seção, com a intenção de apresentá-los como resíduos potencialmente poluidores do meio ambiente, bem como desenvolver o conceito, as características, as classificações e o descarte desses resíduos. Também foi feita uma apresentação dos tipos de aterros: conceitos e definições, além das alternativas sustentáveis para mitigação dos impactos ambientais.

A terceira seção discorreu sobre a metodologia utilizada durante a pesquisa: os caminhos percorridos, os métodos e a abordagem de análise de dados, o campo de pesquisa e as ações educativas.

$\mathrm{Na}$ quarta seção, foram apresentados os resultados que foram obtidos durante o percurso da pesquisa e as discussões que permearam todo o trabalho. 
A seção cinco apresentou as considerações acerca do material produzido como produto final desta pesquisa: construção da cartilha educativa, intitulada Sequência didática para inclusão da sustentabilidade no espaço escolar e comunidade: alternativas sustentáveis para os óleos e gorduras residuais de fritura, bem como seus objetivos e orientações sobre uso e aplicação.

A sexta seção ressalta as considerações finais da dissertação e algumas sugestões para trabalhos futuros.

\subsection{JUSTIFICATIVA}

A motivação para a realização desta pesquisa justifica-se pela necessidade de se trabalhar o ensino das ciências ambientais no contexto escolar e comunidade, a fim de sensibilizar as pessoas, desde a infância, para a responsabilidade socioambiental. Nesta pesquisa, utilizou-se os óleos e gorduras residuais de fritura para a abordagem do tema. Dessa maneira, por se tratar de resíduos que, geralmente, são manipulados por quem prepara os alimentos, a integração dos pais e/ou responsáveis e comunidade foram essenciais para o desenvolvimento da pesquisa acerca dos resíduos sólidos, em específico os óleos e gorduras residuais de fritura, visto que "é cada vez mais notória a complexidade do processo de transformação de um planeta não apenas cada vez mais ameaçado, mas também diretamente afetado pelos riscos socioambientais e seus danos" (JACOBI, 2005, p. 243).

Em segundo momento, busca-se desenvolver práticas pedagógicas interdisciplinares que possibilitem a inserção e/ou atualização dos conhecimentos com o intuito de sensibilização socioambiental, buscando a transformação da realidade dos envolvidos.

\subsection{PERGUNTAS DE PESQUISA}

Com o desenvolvimento da pesquisa, objetiva-se responder às seguintes questões: Como levar para a sala de aula materiais que sensibilizam os participantes para as questões ambientais, mais especificamente, que despertem a 
responsabilidade socioambiental para o manejo dos óleos e gorduras residuais de fritura? Quais instrumentos utilizar para o levantamento dos conhecimentos prévios e o processo de sensibilização a respeito da temática, junto aos pais e/ou comunidade? Os materiais produzidos poderão subsidiar o trabalho de outros profissionais interessados pela temática?

\subsection{OBJETIVOS}

\subsubsection{Objetivo Geral}

Desenvolver atividades sistematizadas para ensino das ciências ambientais direcionadas aos anos finais do ensino fundamental I, que auxiliem no processo de construção da consciência ecológica e sensibilização de alunos, pais e/ou responsáveis e comunidade.

\subsubsection{Objetivos Específicos}

- Analisar a relevância da prática educacional por meio de atividades sistematizadas e interdisciplinares para o ensino das ciências ambientais e responsabilidade socioambiental, em específico, os óleos e gorduras residuais de fritura;

- Investigar a forma como os pais e/ou responsáveis e comunidade relacionam os problemas ambientais a seus hábitos diários, com intuito de contribuir para a responsabilidade socioambiental;

- Produzir uma cartilha educativa com práticas pedagógicas interdisciplinares como instrumento de ensino das ciências ambientais para a sustentabilidade. 


\section{REVISÃO DA LITERATURA}

\subsection{ENSINO DAS CIÊNCIAS AMBIENTAIS E A EDUCAÇÃO AMBIENTAL}

Neste capítulo, pretende-se expor os conceitos de ciências ambientais e educação ambiental, e suas implicações no contexto educacional formal.

Segundo Miller Jr. (2007), a ciência ambiental caracteriza-se como um estudo interdisciplinar sobre o funcionamento da Terra e formas de interação, valendo-se de informações das áreas de ciências físicas (biologia, química e geologia) e das ciências sociais (economia, política e ética).

Ainda de acordo com o documento de área das ciências ambientais da Coordenação de Aperfeiçoamento de Pessoal de Nível Superior (CAPES, 2019), a interdisciplinaridade é uma emergência da área, face às questões ambientais contemporâneas.

A EA tem o propósito de transformar a consciência humana, mudar concepções de pensamento e quebrar paradigmas por meio da sensibilização para as questões ambientais, rumo à sustentabilidade.

Segundo a PNEA, em seu Art. 1ํ, entende-se a EA a partir de:

[...] processos por meio dos quais o indivíduo e a coletividade constroem valores sociais, conhecimentos, habilidades, atitudes e competências voltadas para a conservação do meio ambiente, bem de uso comum do povo, essencial à sadia qualidade de vida e sua sustentabilidade (BRASIL, 1999).

Sendo os princípios básicos da EA, de acordo com o PNEA, Art. 4:

a) o enfoque humanista, holístico, democrático e participativo;

b) a concepção do meio ambiente em sua totalidade, considerando a interdependência entre o meio natural, o socioeconômico e o cultural, sob o enfoque da sustentabilidade;

c) o pluralismo de ideias e concepções pedagógicas, na perspectiva da inter, multi e transdisciplinaridade;

d) a vinculação entre a ética, a educação, o trabalho e as práticas sociais;

e) a garantia de continuidade e permanência do processo educativo;

f) a permanente avaliação crítica do processo educativo;

g) a abordagem articulada das questões ambientais locais, regionais, nacionais e globais;

h) reconhecimento e o respeito à pluralidade e à diversidade individual e cultural. (BRASIL, 1999) 
A EA, desde a CF de 1988, Leis de Diretrizes e Bases da Educação Nacional (LDBN 9.394/96), Parâmetros Curriculares Nacionais (PCN, 1997), PNEA (1999), até a Base Nacional Comum Curricular (BNCC, 2017), é apresentada como interdisciplinar e transversal, devendo perpassar todas as áreas do conhecimento, vinculada à realidade dos envolvidos.

Dessa maneira, infere-se que as ciências ambientais aprofundam-se no campo da alfabetização científica ${ }^{1}$, enquanto a EA, como instrumento de ensino, abrange os processos formativos relacionados a valores sociais e sensibilização de pessoas para participar e atuar com responsabilidade na sociedade.

\subsection{HISTÓRICO DA EDUCAÇÃO AMBIENTAL}

À época da Revolução Industrial, datada do século XVIII, novos processos produtivos foram criados devido ao crescimento populacional e às suas necessidades de consumo. Dessa maneira, intensificou-se a extração de recursos naturais para a fabricação em larga escala, aumento dos resíduos e, como consequência, o agravamento dos problemas ambientais.

Segundo Jacquard (1998), por volta do século XVIII, a população mundial era, em média, 800 milhões de habitantes, um número relativamente pequeno se comparado aos números atuais. De acordo com as últimas projeções da Organização das Nações Unidas (ONU), divulgadas em agosto de 2019, a população mundial foi estimada em 7,7 bilhões.

Frente às questões apresentadas, despontou-se um cenário de preocupação com a degradação e extração dos recursos naturais ameaçando as diversas formas de vida no Planeta.

De acordo com DIAS (2003), em 1965, durante a Conferência de Educação, na universidade de Kelle, Grã-Bretanha, foi utilizado pela primeira vez o termo: Environmental Education (Educação Ambiental), inserindo-o na educação de todos os cidadãos, com enfoque na conservação ou ecologia aplicada.

\footnotetext{
1 Segundo CHASSOT (2003), o termo "alfabetização científica" envolve o conhecimento e a compreensão da ciência, possibilitando ao indivíduo uma leitura crítica do mundo.
} 
No Brasil, a EA, como atividade pedagógica, iniciou-se na década de 1970, momento em que o país vivia o período ditatorial, reprimindo as mais diversas formas de expressão de pensamento (LIMA, 2009). Durante esse período, o país ascendia em relação ao crescimento econômico e industrial, sendo a EA um obstáculo ao crescimento.

A Declaração de Estocolmo, publicada pela Conferência das Nações Unidas (1972) e realizada pela ONU, tratou das questões relacionadas ao Meio Ambiente, no intuito de estabelecer a todos os povos do mundo critérios e princípios comuns sobre a preservação do meio ambiente. Nessa conferência, foi criada a Declaração de Estocolmo sobre o Meio Ambiente Humano, que proclamou:

\begin{abstract}
Chegamos a um momento da história em que devemos orientar nossos atos em todo o mundo com particular atenção às consequências que podem ter para o meio ambiente. Por ignorância ou indiferença, podemos causar danos imensos e irreparáveis ao meio ambiente da terra do qual dependem nossa vida e nosso bem-estar. Ao contrário, com um conhecimento mais profundo e uma ação mais prudente, podemos conseguir para nós mesmos e para nossa posteridade, condições melhores de vida, em um meio ambiente mais de acordo com as necessidades e aspirações do homem. As perspectivas de elevar a qualidade do meio ambiente e de criar uma vida satisfatória são grandes. É preciso entusiasmo, mas, por outro lado, serenidade de ânimo, trabalho duro e sistemático. Para chegar à plenitude de sua liberdade dentro da natureza, e, em harmonia com ela, o homem deve aplicar seus conhecimentos para criar um meio ambiente melhor. A defesa e o melhoramento do meio ambiente humano para as gerações presentes e futuras se converteram na meta imperiosa da humanidade, que se deve perseguir, ao mesmo tempo em que se mantêm as metas fundamentais já estabelecidas, da paz e do desenvolvimento econômico e social em todo o mundo, e em conformidade com elas. (CONFERÊNCIA DAS NAÇÕES UNIDAS SOBRE O MEIO AMBIENTE, 1972, § 6).
\end{abstract}

Após a Conferência de Estocolmo (1972), a EA passou a ser debatida em todos os eventos relacionados ao meio ambiente, no intuito de minimizar a crise ambiental no mundo.

Ainda da Conferência de Estocolmo, criou-se o Programa das Nações Unidas para o Meio Ambiente (PNUMA), que, em parceria com a Organização das Nações Unidas para a Educação, a Ciência e a Cultura (UNESCO), tratariam da EA referente às Nações Unidas.

A UNESCO (1975) realizou o Seminário de Belgrado em resposta às recomendações da Conferência de Estocolmo, onde se elaborou princípios e 
orientações para a EA - que deveria ser contínua, multidisciplinar, considerando os aspectos da realidade local e global.

Desse encontro, originou-se a Carta de Belgrado, que declara a EA como forma de:

Desenvolver um cidadão consciente do ambiente total; preocupado com os problemas associados a esse ambiente, e que tenha o conhecimento, as atitudes, motivações, envolvimento e habilidades para trabalhar de forma individual às questões daí emergentes. (UNESCO, 1975)

Ainda, por meio de organização da UNESCO (1977), ocorreu o mais

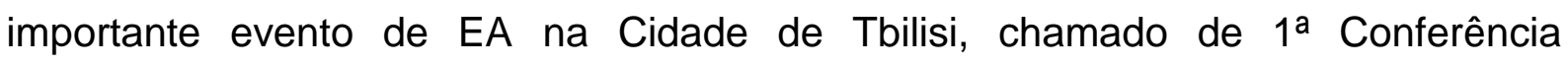
Intergovernamental sobre EA, que tomou como referência a Carta de Belgrado na elaboração de princípios e estratégias que orientam a EA até os dias atuais, destacando a relevância da EA para a preservação e melhoria do meio ambiente, além de desenvolvimento mundial equilibrado.

A Declaração de Tbilisi (1977) também fortalece que a EA deve estar inserida em todos os níveis de ensino, abrangendo todas as faixas etárias, dentro e fora do sistema educacional formal (UNESCO, 1977).

$\mathrm{Na}$ década de 1980, a partir de um estudo chefiado pela 1a ministra da Noruega, Gro Harlem Brundtland, foi publicado o Relatório Brundtland ou Nosso Futuro Comum, que traz o conceito de Desenvolvimento Sustentável:

\footnotetext{
$\mathrm{Na}$ sua essência, o desenvolvimento sustentável é um processo de mudança no qual a exploração dos recursos, o direcionamento dos investimentos, a orientação do desenvolvimento tecnológico e a mudança institucional estão em harmonia e reforçam o atual e futuro potencial para satisfazer as aspirações e necessidades humanas. (COMISSÃO MUNDIAL SOBRE AMBIENTE E DESENVOLVIMENTO, 1991, p. 49)
}

Após 20 anos da Conferência de Estocolmo, a ONU (1992) realizou a Rio-92, também chamada de Cúpula da Terra na qual a relação entre meio ambiente e desenvolvimento sustentável foi apresentada e reconhecida por todo o Mundo. Nesta conferência, os 179 países participantes acordaram e assinaram a Agenda 21 que se caracteriza como um plano de ação abrangente a ser adotado nas esferas global, nacional e local, para proteção e desenvolvimento sustentável do Planeta, abarcando duas décadas de trabalho, a partir da Conferência de Estocolmo (1972). 
A ONU (2002) organizou a Rio+10 em Joanesburgo (África do Sul), sendo uma Cúpula para implementação da Agenda 21, realizada com objetivo de transformar metas, promessas e compromissos em ações concretas.

No ano de 2012, foi realizada a Conferência das Nações Unidas sobre o Desenvolvimento Sustentável, a Rio+20, marcando 20 anos da Rio-92. O objetivo foi a renovação do compromisso político com o desenvolvimento sustentável e teve como principais temas:

a) a economia verde no contexto do desenvolvimento sustentável e da erradicação da pobreza;

b) a estrutura institucional para o desenvolvimento sustentável. (CONFERÊNCIA DAS NAÇÕES UNIDAS SOBRE O MEIO AMBIENTE E O DESENVOLVIMENTO, 1992).

A ONU (2015) realizou também o encontro da Cúpula de Desenvolvimento Sustentável em Nova York a fim de definir os objetivos do Desenvolvimento Sustentável (ODS), sendo uma oportunidade de reunir os países e adotar uma nova agenda, contendo planos de ação para acabar com a pobreza, promover bem-estar e prosperidade a todos, proteger o meio ambiente e enfrentar as mudanças climáticas.

É notório que, a partir da Revolução Industrial, quando as demandas de produção foram intensificadas, começaram a surgir, consequentemente, os agravos ambientais e as mobilizações por meio das Conferências. Dessa maneira, todas elas caminhavam direcionadas a solucionar os problemas de ordem ambiental mediante critérios e princípios comuns a todos os povos do Mundo, sem distinção. E, desde a Conferência de Estocolmo, as práticas relacionadas à sensibilização das pessoas já se apresentavam como um processo contínuo e interdisciplinar, devendo considerar os aspectos local e global. 


\subsection{LEGISLAÇÃO DA EDUCAÇÃO BRASILEIRA E ABORDAGEM DA TEMÁTICA MEIO AMBIENTE}

A partir da trajetória histórica da $E A$, já referenciada, várias Leis e documentos foram criados a fim de regular, definir e assegurar os direitos e deveres dos cidadãos.

Dentre as Leis que amparam o contexto escolar, foram estabelecidas, em 1996, a Lei de Diretrizes e Bases da Educação Nacional (LDBEN: 9.394/96), que veio, de acordo com o seu Art. 9º, inciso IV:

[...] estabelecer, em colaboração com os Estados, o Distrito Federal e os Municípios, competências e diretrizes para a educação infantil, o ensino fundamental e o ensino médio, que nortearão os currículos e seus conteúdos mínimos, de modo a assegurar formação básica comum. (BRASIL, 1996)

Dentre os artigos da LDBEN (1996), quanto aos níveis escolares, o Art. 21 afirma que a educação escolar compõe-se de:

\footnotetext{
a) educação básica, formada pela educação infantil, ensino fundamental e ensino médio;

b) educação superior. (BRASIL, 1996)
}

Ainda de acordo às Disposições Gerais da LDBEN (1996), o Art. 22 estabelece: "A educação básica tem por finalidades desenvolver o educando, assegurar-Ihe a formação comum indispensável para o exercício da cidadania e fornecer-lhe meios para progredir no trabalho e em estudos posteriores" (BRASIL, 1996).

No contexto da LDBEN (1996), verifica-se que são citados, em específico, que o conhecimento do mundo físico e natural deve fazer parte dos currículos da educação infantil, ensino fundamental e ensino médio (BRASIL, 1996). Dessa maneira, infere-se que o ensino das ciências ambientais deverá fazer parte dos conhecimentos do indivíduo para que ele possa, de fato, exercer a cidadania frente às questões socioambientais. 
Ressalta-se que o ensino das ciências ambientais é uma temática muito complexa e se relaciona com diferentes áreas do conhecimento, sendo impossível ser caracterizada como uma única disciplina devido ao seu caráter interdisciplinar e transversal, devendo perpassar todo o currículo escolar.

Ainda de acordo com os documentos orientadores da Educação Básica, de caráter não obrigatório, os Parâmetros Curriculares Nacionais (PCNs, 1997) e as Diretrizes Curriculares da Educação Nacional (DCNs, 2013), que são referências para a organização dos currículos escolares nos níveis da educação básica, reiteram a importância da inclusão das questões ambientais integradas a todas as disciplinas constantes do currículo por meio de temas relacionados ao meio ambiente e à sustentabilidade.

Vale ressaltar que os PCNs (1997) estão divididos por área do conhecimento e por níveis de ensino (ensino fundamental e médio). Além de abarcar todas as áreas do conhecimento, possuem ainda a parte diversificada do currículo, que se constitui dos temas transversais: Ética, Pluralidade Cultural, Meio ambiente, Saúde e Orientação Sexual (BRASIL, 1997).

É notório que os objetivos dos temas transversais, nos PCNs, devem ser tratados "ao lado do conhecimento de fatos e situações marcantes da realidade brasileira, de informações e práticas que the possibilitem participar ativa e construtivamente dessa sociedade [...]" (BRASIL, 1997, p. 39).

Assim como os PCNs (1997), as DCNs também estão divididas por área do conhecimento, e a parte diversificada deve integrar a educação fundamental e a Vida Cidadã. A função da escola de preparar os alunos para a vida cidadã está estabelecida pelo Parecer CNE/CEB no 4/98 que embasa as DCNs para a Educação Básica:

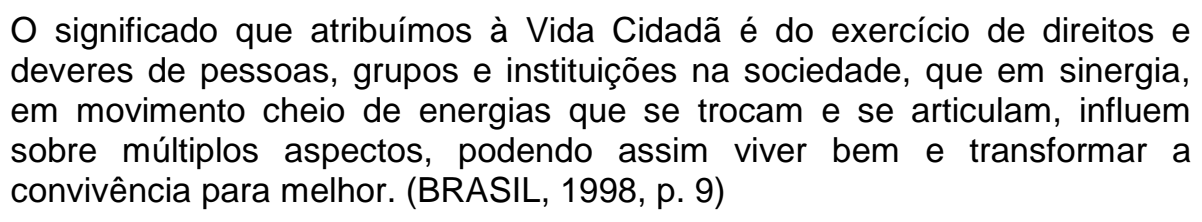

A EA consta das DCNs (2013) como parte diversificada do currículo:

- visa à construção de conhecimentos, ao desenvolvimento de habilidades, atitudes e valores sociais, ao cuidado com a comunidade de 
vida, à justiça, à equidade socioambiental e à proteção do meio ambiente natural e construído;

- não é atividade neutra, pois envolve valores, interesses, visões de mundo; desse modo, deve assumir, na prática educativa, de forma articulada e interdependente, as suas dimensões política e pedagógica;

- deve adotar uma abordagem que considere a interface entre a natureza, a sociocultural, a produção, o trabalho, o consumo, superando a visão despolitizada, acrítica, ingênua e naturalista ainda muito presente na prática pedagógica das instituições de ensino;

- deve ser integradora, em suas múltiplas e complexas relações, como um processo contínuo de aprendizagem das questões referentes ao espaço de interações multidimensionais, seja biológica, física, social, econômica, política e cultural. Ela propicia mudança de visão e de comportamento mediante conhecimentos, valores e habilidades que são necessários para a sustentabilidade, protegendo o meio ambiente para as gerações presentes e futuras. (BRASIL, 2013, p. 522-523)

Ainda de acordo as DCNs (2013), no que se refere à EA, o

[...] atributo "ambiental" na tradição da Educação Ambiental brasileira e latino-americana não é empregado para especificar um tipo de educação, mas constitui-se em elemento estruturante que demarca um campo político de valores e práticas, mobilizando atores sociais comprometidos com a prática político-pedagógica transformadora e emancipatória capaz de promover a ética e a cidadania ambiental. (BRASIL, 2013, p. 515)

Recentemente, em 2017, aprovou-se a Base Nacional Comum Curricular (BNCC), em sua terceira versão, constituindo-se como referência na organização curricular dos sistemas públicos e privados de ensino, de caráter obrigatório. A BNCC define as aprendizagens essenciais ao longo dos níveis da educação básica com o objetivo do desenvolvimento humano global, fundamentando-se em dez competências gerais (BRASIL, 2017).

O conceito de competências pela BNCC é apresentado como:

[...] mobilização de conhecimentos (conceitos e procedimentos), habilidades (práticas, cognitivas e socioemocionais), atitudes e valores para resolver demandas complexas da vida cotidiana, do pleno exercício da cidadania e do mundo do trabalho. (BRASIL, 2017, p. 8)

Assim, dentre as competências da BNCC (2017), no tocante às questões ambientais, o educando deve:

Argumentar com base em fatos, dados e informações confiáveis, para formular, negociar e defender ideias, pontos de vista e decisões comuns que respeitem e promovam os direitos humanos, a consciência socioambiental e o consumo responsável em âmbito local, regional e global, 
com posicionamento ético em relação ao cuidado de si mesmo, dos outros e do planeta. (BRASIL, 2017, 8ª competência, p. 9)

A BNCC está estruturada por área do conhecimento, sendo os componentes curriculares alinhados às suas respectivas áreas:

Figura 1 - Estrutura BNCC

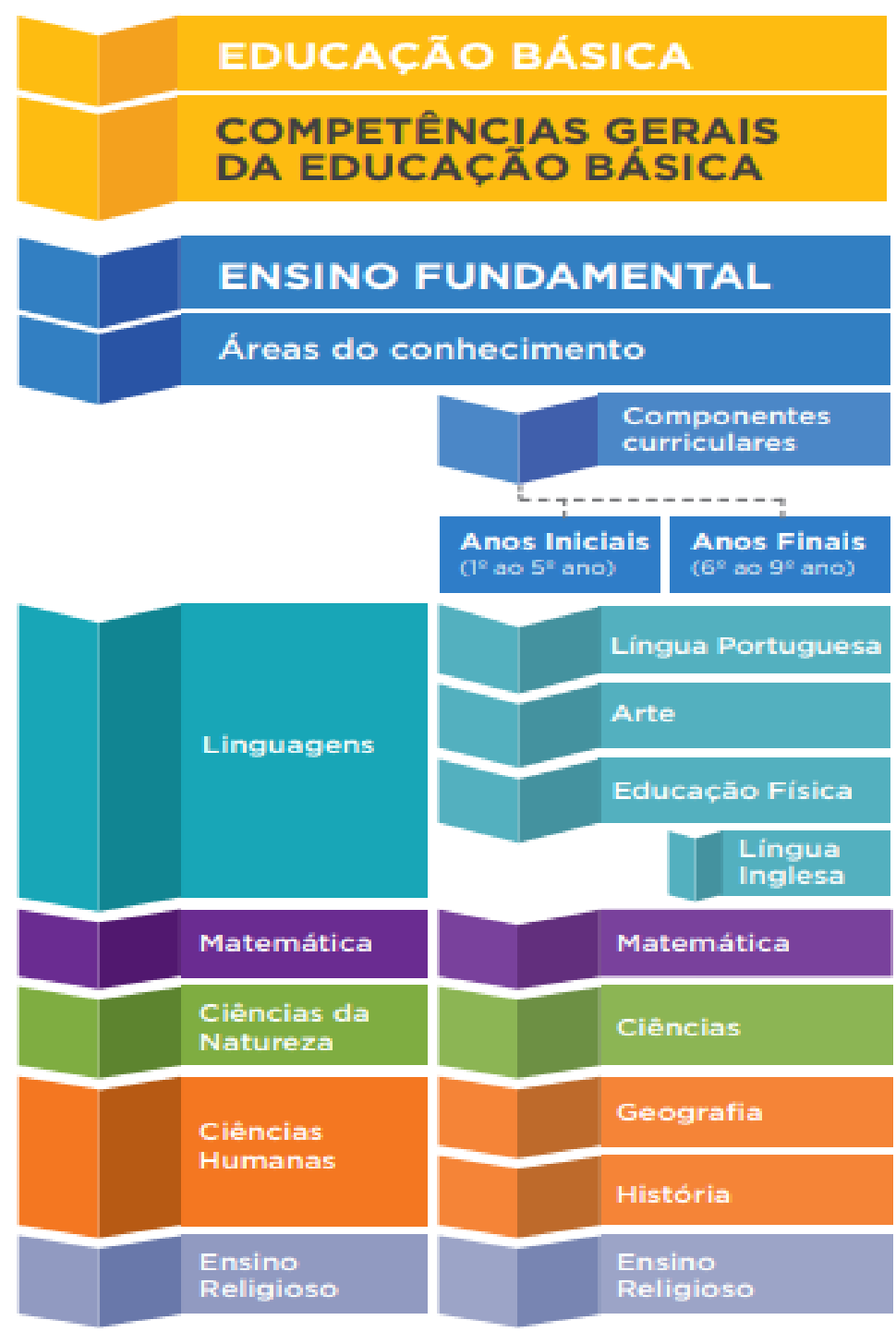

Fonte: BRASIL (2017, p. 27).

Vale ressaltar que o desenvolvimento humano global em suas dimensões: intelectual, física, afetiva, social, ética, moral e simbólica está ancorado nas dez competências gerais da educação básica. De acordo à Organização para a 
Cooperação e Desenvolvimento Econômico (OCDE, 2018) o foco no desenvolvimento de competências também foi adotado nas avaliações do Programa Internacional de Avaliação de Estudantes (PISA), que permite a cada país avaliar os conhecimentos e habilidades de seus estudantes e comparar os resultados entre os países, visando melhoria na qualidade de ensino.

Nessa Base, assim como nos PCNs e DCNs, as questões relacionadas ao meio ambiente inserem-se na parte diversificada do currículo e são chamadas de Temas Contemporâneos Transversais (TCTs), enfatizando o termo sustentabilidade. Assim, os TCTs devem ser trabalhados, preferencialmente, de forma transversal, integrados aos demais componentes curriculares e focado nas dez competências constantes da base.

Ainda no capítulo introdutório da BNCC, destaca-se que as competências estão alinhadas à Agenda 2030 da ONU por fomentarem ações que contribuem para o desenvolvimento humano global e transformação da sociedade.

Assim:

\begin{abstract}
Em nome dos povos que servimos, nós adotamos uma decisão histórica sobre um conjunto de Objetivos e metas universais e transformadoras que é abrangente, de longo alcance e centrado nas pessoas. Comprometemo-nos a trabalhar incansavelmente para a plena implementação desta Agenda em 2030. Reconhecemos que a erradicação da pobreza em todas as suas formas e dimensões, incluindo a pobreza extrema, é o maior desafio global e um requisito indispensável para o desenvolvimento sustentável. Estamos empenhados em alcançar o desenvolvimento sustentável nas suas três dimensões - econômica, social e ambiental - de forma equilibrada e integrada. (ORGANIZAÇÃO DAS NAÇÕES UNIDAS, 2015, p. 03)
\end{abstract}

Sabe-se que, desde a Lei no 9.394/96 (LDBEN), que regulamenta a educação básica brasileira, ancorada nos princípios da CF de 1988, já se assegura a formação básica comum a todos os cidadãos, bem como uma parte diversificada do currículo (TCTs) que deve abarcar os conhecimentos de mundo, de cunho social, para que 0 indivíduo possa participar ativamente no exercício da cidadania. Dessa maneira, as questões ambientais estão inseridas nos TCTs e são, portanto, essenciais para a formação integral do cidadão.

Conforme observado nas Leis e documentos aqui descritos, a BNCC, último documento aprovado e de caráter obrigatório para a organização do currículo escolar das instituições públicas e privadas de educação básica, foi elaborada à luz das LDBEN (1996), PCNs (1997) e DCNs (2013), no intuito de atualizar os currículos 
e incluir as pautas provenientes das Leis e Conferências realizadas no decorrer da trajetória, buscando o aprimoramento da educação para a formação de um cidadão cada vez mais comprometido com a sociedade.

\subsection{CORRENTES DE EDUCAÇÃO AMBIENTAL CONSERVACIONISTA E CRÍTICA}

É evidente que o ensino das ciências ambientais é tarefa complexa e abrangente, pois, na contemporaneidade são muitas as questões que envolvem a temática.

Hodiernamente, a educação básica, bem como os TCTs, estão ancorados na BNCC e deliberados por leis. Concernente à temática meio ambiente, a PNEA (Lei n. 9.795/99) é referência, e diz:

Art. $1^{\circ}$ Entende-se por educação ambiental os processos por meio dos quais o indivíduo e a coletividade constroem valores sociais, conhecimentos, habilidades, atitudes e competências voltadas para a conservação do meio ambiente, bem de uso comum do povo, essencial à sadia qualidade de vida e sua sustentabilidade. (BRASIL, 1999)

Dessa maneira, os temas relacionados ao meio ambiente devem ser integrados aos componentes curriculares de maneira interdisciplinar e transversal, pautados na realidade local e global.

Art. 10 A educação ambiental será desenvolvida como uma prática educativa integrada, contínua e permanente em todos os níveis e modalidades do ensino formal. (BRASIL, 1999)

Assim sendo, o ensino das ciências ambientais para inclusão da sustentabilidade no âmbito escolar pode ser desenvolvido por meio de várias vertentes de educação.

Ao longo da trajetória dos movimentos em prol das questões socioambientais, diferentes vertentes educacionais foram surgindo, de acordo aos elementos políticos e sociais do momento.

No Brasil, a EA foi inserida como atividade pedagógica na década de 1970, época em que o regime político do País era a Ditadura Militar, regime no qual não era permitida a liberdade de expressão (LIMA, 2009). Mais tarde, com o agravamento dos problemas de ordem ambiental, organizações sociais começaram 
a pensar o trabalho numa abordagem diferente, embutindo outros aspectos de ordem social, além dos ambientais (DIAS, 2003).

É sabido que, com o surgimento das várias vertentes de EA, os professores não tinham conhecimento sobre as peculiaridades de cada uma delas, no entanto, a vertente de EA conservadora era a única utilizada pelo público não especializado (LAYRARGUES; LIMA, 2011; LAYRARGUES, 2012 apud SANTOS; TOSCHI, 2015).

De acordo com Sauvé (2005), a EA, além de tratar de temáticas relacionadas ao meio ambiente, é necessário conhecer os processos educativos e a interação entre eles, segundo o objetivo a que se persegue. Dessa maneira, Sauvé (2005) define 15 correntes diferentes, porém, aqui serão abordadas apenas as correntes: conservacionista e crítica.

A corrente conservacionista já se fazia presente desde a década de 1970, quando o foco estava na conservação da natureza enquanto recursos naturais e materiais, assim como foi prevista na Conferência de Educação na Universidade de Kelle, em 1965. A vertente crítica de EA é mais ampla, pois possibilita uma leitura de mundo mais aprofundada, corroborando com os objetivos da educação contemporânea, baseada nos princípios de Paulo Freire (1921-1997).

De acordo com a PNEA (1999) e a BNCC (2017), as questões de ordem ambiental devem ser desenvolvidas de maneira processual, possibilitando ao indivíduo a construção de valores sociais, habilidades e competências para participar e transformar a própria realidade.

Segundo Loureiro (2012), a EA na perspectiva conservadora centra-se nas ações e visa à transmissão de conhecimentos com o intuito de fomentar mudanças de comportamentos, porém, desvinculado da realidade local e descontextualizado dos problemas ambientais em nível global. Na perspectiva crítica da EA, também chamada de emancipatória e transformadora, as ações estão centradas na sensibilização, transformação do indivíduo por meio do desenvolvimento do senso crítico e preparação para agir na sua própria realidade.

Dessa maneira, segundo Loureiro (2006), à tradição crítica de EA não cabe:

[...] discutir conservação sem considerar os processos sociais que levaram ao atual quadro de esgotamento e extinção; falar em mudanças de comportamentos sem pensar como cada indivíduo vive, seu contexto e suas possibilidades concretas de fazer escolhas; defender uma forma de pensar a natureza, ignorando como cada civilização, cada sociedade e cada comunidade interagiam nela e definiam representações sobre ela; como 
produziam, geravam cultura e estilos de vida e como isso se dá hoje. (LOUREIRO, 2006, p. 70)

Observa-se que, ao longo da trajetória da EA e, de acordo com os acontecimentos que agravaram os problemas, novas formas de desenvolver as ciências ambientais eram pensadas e propostas. Assim, pretendeu-se enfatizar aqui as vertentes de EA nas perspectivas: conservacionista, que por sua vez é uma das mais antigas correntes e uma das mais utilizadas em torno da década de 1970; e na vertente crítica, que, à medida que os agravos das questões ambientais ocorriam, necessitava ser incluída no trabalho cotidiano, abordando aspectos local e global.

E ainda conforme os documentos criados a partir das Conferências de EA, ao longo da história, houve a necessidade de uma educação focada em valores sociais, competências e habilidades voltadas à transformação da própria realidade do indivíduo. Dessa maneira, nos dias atuais, é fundamental trabalhar as ciências ambientais por meio da perspectiva crítica de educação.

\subsection{ELEMENTOS HISTÓRICOS E VERTENTES EDUCACIONAIS}

Segundo Paiva (2015), os elementos históricos e vertentes educacionais foram se formando a partir do legado jesuítico. Desde os primórdios da educação, tomando como ponto de partida a Idade Média (1549-1759), época em que a educação baseava-se em princípios religiosos e sob a luz da vertente tradicional de ensino, a educação não era acessível a todos, apenas a pequenos grupos hierárquicos privilegiados.

No período chamado de Idade Moderna, à época da Revolução Industrial, houve-se a necessidade de ensino para todos baseado em princípios de preparação de mão de obra para ascensão da indústria. Nos períodos da Idade Média e Moderna, predomínio da vertente tradicional de ensino ou pedagogia hegemônica, a educação era pautada na figura do professor e o enfoque estava no ensino da escrita por meio de memorização de conteúdos.

No decorrer da história, outras vertentes educacionais foram surgindo, o que se pode inferir que o processo educativo é regido por fatores políticos e sociais do momento. 
Assim, no século $X X$, foram surgindo novas vertentes contra-hegemônicas: a Pedagogia Histórico-Crítica, de Saviani; a Pedagogia Crítico-Social dos Conteúdos, de Libâneo; e a Pedagogia Popular, de Paulo Freire. Vertentes essas estudadas com base na necessidade de formação do indivíduo para atuar na sociedade em questão.

De acordo com esta pesquisa, adentrar-se-á diretamente na Pedagogia popular de Paulo Freire sob a perspectiva crítica de educação.

Considerado uma das principais referências da educação brasileira, o educador e filósofo Paulo Freire (1921-1997), defendeu, durante toda a sua trajetória, a educação como forma de libertação e emancipação, partindo sempre da realidade do indivíduo. Nesse sentido, Freire (1980), assegura que o homem deve ser capaz de perceber as questões que o cerca e agir criticamente na sua própria realidade. Assim:

[...] é preciso que a educação esteja - em seu conteúdo, em seus programas e em seus métodos - adaptada ao fim que se persegue: permitir ao homem chegar a ser sujeito, construir-se como pessoa, transformar o mundo, estabelecer com os outros homens relações de reciprocidade, fazer a cultura e a história. (FREIRE, 1980, p. 39)

Em suas obras, Freire pregava uma educação capaz de minimizar a exclusão das classes dominadas, educação libertadora e emancipatória para que o indivíduo possa romper com a alienação e agir criticamente sobre sua própria realidade. "Uma educação para a decisão, para a responsabilidade social e política" (FREIRE, 1979, p. 88).

Paulo Freire, em uma entrevista dada ao veículo de comunicação português O jornal, no dia 02 de maio de 1977, dizia "Não há educação neutra". O que significa dizer que as práticas pedagógicas do educador, enquanto ser social, são dotadas de aspectos políticos e sociais, orientadas por Leis e demais documentos.

É nessa perspectiva que a BNCC (2017) parte da concepção de que escola deve propiciar formação integral ao aluno, incluindo conhecimentos que vão além dos componentes curriculares. Sendo assim, a BNCC dispõe sobre os TCTs, nos quais estão incluídas as questões de ordem ambiental, bem como as orientações para a formação integral do educando - que, ao agir criticamente, consegue a transformação de sua própria realidade. 
Por meio desses elementos aqui descritos, infere-se que o ensino das ciências ambientais, frente às desordens atuais do meio ambiente e às características do cidadão que se pretende formar, deverá estar ancorado nos ideais da vertente crítica de educação, nas políticas educacionais e ambientais, sob a luz da BNCC (2017).

\subsection{ESCOLA, FAMÍLIA E COMUNIDADE}

A escola constitui-se como um espaço social de aprendizagem, e, segundo a BNCC (2017), deve estar comprometida com a formação integral do aluno em suas dimensões intelectual, física, afetiva, social, ética, moral e simbólica (BRASIL, 2017).

Nesse sentido, a escola configura-se como um espaço privilegiado para interação e transformação social.

É notório que, para o desenvolvimento humano global, a parceria entre família, escola e comunidade é fundamental, sendo, a família, a primeira responsável por orientar o indivíduo desde o nascimento.

De acordo a LDBEN (1996):

A educação abrange os processos formativos que se desenvolvem na vida familiar, na convivência humana, no trabalho, nas instituições de ensino e pesquisa, nos movimentos sociais e organizações da sociedade civil e nas manifestações culturais (BRASIL, 1996, Art. 1ํ).

Dessa maneira, enquanto filho, o indivíduo possui uma família; enquanto aluno, faz parte de uma instituição de ensino disposta em uma determinada comunidade. Mediante esses aspectos, é necessária a participação da família e da comunidade na escola para que os processos de ensino e aprendizagem sejam pautados na realidade do aluno, tornando-se, portanto, mais significativos.

Partindo dessa concepção, Beatriz Pont (2012), analista das políticas educacionais na Organização para a Cooperação e o Desenvolvimento Econômico (OCDE), concluiu que a articulação de estratégias de aproximação entre família e escola favorece a aprendizagem e fortalece os vínculos. Nesse sentido, infere-se que a participação da família é essencial para que o aluno venha compreender e agir criticamente sobre sua realidade, dentro e fora da escola. 
Para a inclusão da sustentabilidade na escola, foco desta pesquisa, a inserção da família e/ou comunidade se faz necessária principalmente por se tratar de um tema de relevância social; sendo assim, todas as pessoas devem ser sensibilizadas para a responsabilidade socioambiental.

Seguindo essa linha de pensamento, Costa (1998, p. 148 apud SOUZA; SARMENTO, 2009, 2010) asseguram: "a educação possui um carácter eminentemente social que the advém da existência de vários atores sociais com funções educativas $[\ldots] "$.

A educação, como processo formativo que se desenvolve em regime de colaboração entre vários atores sociais: escola, família e comunidade, deve estabelecer uma conexão pautada na responsabilidade de todos. Dessa maneira, a inclusão da sustentabilidade na escola, temática que se enquadra nos TCTs, assegura a sensibilização dos alunos e demais envolvidos.

\subsection{ATIVIDADES SISTEMATIZADAS - SEQUÊNCIA DIDÁTICA}

No contexto escolar, o educador necessita lançar mão de diferentes estratégias de ensino na busca pela construção do conhecimento. É notório que, conteúdos fragmentados, sem conexão entre os componentes do currículo, não colaboram para o desenvolvimento integral do aluno, portanto, não estão alinhadas à BNCC, que reitera a relevância da integração entre os componentes curriculares e os TCTs de maneira interdisciplinar e transversal.

Nesse sentido, temas relacionados às questões ambientais, como parte dos TCTs, devem ser previamente planejados e articulados aos demais componentes curriculares.

Partindo dessa perspectiva, as atividades sistematizadas que se constituem em sequência didática (SD) contribuem significativamente para $\circ$ processo progressivo da aprendizagem, uma vez que, de acordo com Zaballa (1998, p.18), configuram-se como "um conjunto de atividades ordenadas, estruturadas e articuladas para a realização de certos objetivos educacionais, que têm um principio e um fim conhecido tanto pelos professores como pelos alunos". Nas sequências didáticas, quanto à temática Meio Ambiente, encontram-se várias possibilidades de 
integração aos demais componentes do currículo por ter interfaces com saneamento, sociedade, economia, entre outros.

Dessa maneira, os currículos escolares, de acordo a BNCC (2017), necessitam:

- contextualizar os conteúdos dos componentes curriculares, identificando estratégias para apresentá-los, representá-los, exemplificá-los, conectá-los e torná-los significativos, com base na realidade do lugar e do tempo nos quais as aprendizagens estão situadas;

- selecionar e aplicar metodologias e estratégias didático-pedagógicas diversificadas, recorrendo a ritmos diferenciados e a conteúdos complementares, se necessário, para trabalhar com as necessidades de diferentes grupos de alunos, suas famílias e cultura de origem, suas comunidades, seus grupos de socialização etc.;

- conceber e pôr em prática situações e procedimentos para motivar e engajar os alunos nas aprendizagens. (BRASIL, 2017, p. 16-17),

Contudo, verifica-se a complexidade do fazer educativo na necessidade de se elaborar estratégias diferenciadas de ensino e articular todo o contexto em favor da aprendizagem, buscando despertar o engajamento dos envolvidos para a formação integral e exercício da cidadania.

\subsection{RESÍDUOS SÓLIDOS: CONCEITO E CLASSIFICAÇÃO}

A Associação Brasileira de Normas Técnicas (ABNT NBR 10004:2004) é responsável por regulamentar e classificar os resíduos sólidos, considerando as questões de ordem ambiental de acordo com os critérios relacionados ao desenvolvimento sustentável.

Conforme as definições da ABNT NBR (10004:2004), os resíduos sólidos são:

Resíduos nos estados sólido e semissólido, que resultam de atividades de origem industrial, doméstica, hospitalar, comercial, agrícola, de serviços e de varrição. Ficam incluídos nesta definição os lodos provenientes de sistemas de tratamento de água, aqueles gerados em equipamentos e instalações de controle de poluição, bem como determinados líquidos cujas particularidades tornem inviável o seu lançamento na rede pública de esgotos ou corpos de água, ou exijam para isso soluções técnica e economicamente inviável em face à melhor tecnologia disponível (ABNT NBR 10004:2004, p. 01).

Quanto à periculosidade de um resíduo, aponta também que é: 
Característica apresentada por um resíduo que, em função de suas propriedades físicas, químicas ou infectocontagiosas, pode apresentar:

- risco à saúde pública, provocando mortalidade, incidência de doenças ou acentuando seus índices;

- riscos ao meio ambiente, quando o resíduo for gerenciado de forma inadequada (ABNT NBR 10004:2004 p. 02).

É notório que os óleos e gorduras residuais de fritura, por se enquadrarem nos resíduos sólidos domésticos, são contabilizados junto aos demais resíduos. Conforme a Associação Brasileira de Empresas de Limpeza Pública e Resíduos Especiais - ABRELPE (2018/2019), os números referentes à geração de resíduos sólidos urbanos revelam um total anual de 79 milhões de toneladas no país. Desse total, foram coletados 72,7 milhões de toneladas, deixando evidente que 6,3 milhões de toneladas de resíduos tiveram destino inadequado, ou seja, foram para aterro controlado e/ou lixões. Ainda a média anual de geração de resíduos foi de 380 $\mathrm{kg} / \mathrm{ano}$ por pessoa, sendo em torno de $1,055 \mathrm{~kg} / \mathrm{dia}$. Verifica-se que o sistema de coleta e a disposição final dos resíduos sólidos não progrediram na mesma proporção do crescimento populacional e do aumento do consumo.

De acordo com a ABNT NBR (10004:2004), os óleos residuais de fritura, objeto de estudo deste trabalho, classificam-se como resíduos sólidos, mesmo não apresentando tais características, pelo fato de não poderem ser descartados nas redes de esgoto ou corpos d'água sem o devido tratamento.

Quanto à periculosidade, classifica-se como perigoso, pois, se não for descartado e/ou tratado adequadamente, apresenta riscos à saúde pública e ao meio ambiente. Embora a ABRELPE apresente os números de resíduos sólidos urbanos gerados, incluindo os Óleos e Gorduras Residuais de Fritura (OGRF), não é possível saber, com precisão, a quantidade de OGRF que é dispensada inadequadamente em lixões ou aterros controlados.

2.8.1 Aterro sanitário, aterro controlado e lixões: conceitos e definições

De acordo com a Companhia Ambiental do Estado de São Paulo (CETESB), Aterro Sanitário é um local destinado ao descarte dos resíduos sólidos, prioritariamente, materiais não recicláveis. As áreas destinadas a esse fim devem 
estar distantes de corpos hídricos e da área urbana, além disso, os terrenos precisam ser previamente preparados com sistema de impermeabilização do solo.

O aterro controlado é uma área onde são descartados os resíduos sólidos, e, conforme o nome que recebe, ele possui algum tipo de controle, porém, está fora das normas ambientais brasileiras e não atendem aos requisitos da PNRS.

Os lixões são terrenos onde são dispensados os resíduos sólidos, sem nenhum controle ambiental e tratamento do lixo, portanto, é, ambientalmente e socialmente, o pior local para dispensação dos resíduos (CETESB, 2017).

Vale ressaltar que os resíduos são provenientes do consumo e, quando não têm mais utilidade, segundo a visão de algumas pessoas, são descartados.

É notório que nem todo resíduo que chega ao aterro não tem mais utilidade. Existem os materiais que podem ser recicláveis, assim como os óleos e gorduras residuais de fritura.

É importante ressaltar que os resíduos sólidos, chamados, popularmente, de lixo, de acordo com as definições da Política Nacional de Resíduos Sólidos (PNRS Lei n.12.305/10), são materiais que ainda têm alguma serventia, podendo ser reutilizados ou reciclados.

Ainda segundo as definições da PNRS (Lei n. 12.305/10):

XIV - reciclagem: processo de transformação dos resíduos sólidos que envolve a alteração de suas propriedades físicas, físico-químicas ou biológicas, com vistas à transformação em insumos ou novos produtos [...]

XVIII - reutilização: processo de aproveitamento dos resíduos sólidos sem sua transformação biológica, física ou físico-química [...]. (BRASIL, 2010)

Sendo assim, tudo o que não tem mais nenhuma utilidade passará a ser chamado de rejeitos, de acordo com a Lei no 12.305/99.

XV - rejeitos: resíduos sólidos que, depois de esgotadas todas as possibilidades de tratamento e recuperação por processos tecnológicos disponíveis e economicamente viáveis, não apresentem outra possibilidade que não a disposição final ambientalmente adequada. (BRASIL, 2010)

Dessa maneira, de acordo com a CETESB, os aterros sanitários deverão receber, prioritariamente, os rejeitos. 
A PNRS também dispõe sobre a coleta seletiva, que tem a função de recolher os resíduos que podem ser reciclados, segregados previamente, conforme sua composição e, posteriormente, tornam-se matérias-primas para outros produtos. E, quando os resíduos não são segregados previamente, chegam ao aterro, onde não existe mecanismo de separação dos materiais recicláveis; portanto, sua vida útil é encerrada ali (BRASIL, 2010).

A presente pesquisa não tem por objetivo aprofundar os conhecimentos relacionados aos aterros, porém, como os óleos e gorduras residuais de fritura são classificados como resíduos sólidos, fez-se necessário levantar alguns conceitos para melhor compreensão.

\subsection{2 Óleos e gorduras residuais de fritura - características e descarte}

Os óleos e gorduras residuais de fritura (OGRF) são resultantes dos processos de preparação de alimentos, em residências e restaurantes, sendo um resíduo de alto potencial poluidor quando descartado inadequadamente.

Os OGRF são substâncias hidrofóbicas, ou seja, insolúveis em água, de origem vegetal e animal. Os principais óleos comestíveis de origem vegetal são provenientes de fontes oleaginosas como: soja, algodão, girassol, dendê, oliva, entre outros; os de origem animal são provenientes do tecido adiposo do animal, normalmente de origem suína (RAMALHO; SUAREZ, 2013).

Segundo a Associação Brasileira para Sensibilização, Coleta e Reciclagem de Resíduos de óleo Comestível (ECOLEO, 2015), o Brasil produz cerca de 9 bilhões de litros por ano. Desse total, 1/3 vai para óleos comestíveis. O consumo individual fica em torno de 20 litros por ano. Em relação ao descarte, cerca de 6 milhões e meio de litros são coletados, totalizando menos de $1 \%$ da quantidade produzida.

Segundo Roviriego (2005 apud LEITE, 1997), a responsabilidade pela gestão dos resíduos sólidos domésticos, no Brasil, compete às prefeituras. Os resíduos sólidos, normalmente, são recolhidos por meio de coleta seletiva, além dos catadores que, geralmente, fazem parte de cooperativas que retiram o material reciclável.

A Lei o 11.445/2007, que estabelece as Diretrizes Nacionais para o Saneamento Básico prevê que a limpeza urbana e o manejo dos resíduos sólidos sejam mantidos pelo poder público por meio direto ou consórcio, observadas as Leis 
que regulamentam os resíduos sólidos urbanos e o Guia para Elaboração dos Planos de Gestão de Resíduos Sólidos do Ministério do Meio Ambiente (MMA). Ainda de acordo com os instrumentos da PNRS, o poder público deve incentivar a criação e o desenvolvimento de cooperativas e/ou associações de catadores de materiais reutilizáveis e recicláveis, assegurando a sustentabilidade econômicofinanceira.

Quanto à separação e acondicionamento dos OGRF, a legislação não dispõe de uma maneira correta, porém, é comum as pessoas armazenarem em garrafas pet, potes de manteigas e potes de vidro.

Como alternativa de práticas sustentáveis, os OGRF constituem-se como matéria-prima para outros produtos. Dentre as formas de reciclagem desse resíduo, o sabão ecológico se apresenta como uma das formas que não exige tecnologia para serem produzidos, podendo ser manipulado em residências, contribuindo para minimizar os impactos ambientais provocados pelo descarte inadequado.

2.8.2.1 Óleos e gorduras residuais de fritura: Impactos ambientais provocados pelo descarte inadequado

É notório que os óleos e gorduras residuais de fritura são resíduos de alto potencial poluidor, se descartados inadequadamente. Os impactos ambientais advindos desses resíduos afetam a água, o solo e o ar, configurando-se como um dos problemas ambientais mais graves da atualidade.

Os OGRF, por serem hidrofóbicos, quando entram em contato com corpos d'água impedem a transferência de oxigênio entre o ar e a água e alteram as características naturais dela por meio da toxicidade dos compostos químicos presentes que, além da poluição, causam a morte dos organismos do ambiente CETESB (2017).

Takanashi (2013 apud LAGO; ROCHA JR. 2016, p. 1442), mencionam que, quando OGRF são descartados no solo, o torna impermeável, infértil para plantação, e, nos períodos de precipitações intensas, forma um líquido percolado que, além de causar odor desagradável, colabora para o aquecimento global por causa do gás metano. 
Ainda de acordo com a empresa de saneamento ambiental (DELTA, 2015), quando os OGRF são descartados pelos ralos da pia e/ou no vaso sanitário, esses resíduos impregnam a tubulação, atraindo pragas e doenças, e, quando atingem a rede de esgoto, o custo para tratamento desses efluentes se eleva em torno de $45 \%$.

São vastas as questões de poluição ambiental em torno dos OGRF. Dessa maneira, é urgente a necessidade de sensibilização para transformação dos indivíduos com o intuito de minimizar os impactos ambientais.

Envolto às questões dos óleos e gorduras residuais de fritura (OGRF), no que diz respeito aos impactos ambientais, estão os processos que são explicados por meio de conceitos da química, que, por motivo de não ser foco desta pesquisa e por desconhecimento da área, não foi possível aprofundar.

\subsubsection{Alternativas sustentáveis para os óleos e gorduras residuais de fritura}

Para pensar em alternativas sustentáveis, é fundamental ter clareza de um dos princípios da PNRS:

O reconhecimento do resíduo sólido reutilizável e reciclável como um bem econômico e de valor social, gerador de trabalho e renda e promotor de cidadania; (BRASIL, 2010, Cap. II, Art. 6º).

A partir do reconhecimento de todo valor agregado em torno dos OGRF, considerando valores sociais, econômicos e ambientais, alguns estudiosos e pessoas do mundo todo começaram a pensar em alternativas de reaproveitamento desses resíduos.

É notório que, a partir da sensibilização das pessoas para as questões de ordem ambiental, é possível transformar a realidade por meio da responsabilidade social para escolhas de alternativas sustentáveis que minimizem os impactos ambientais, além da viabilidade econômica e possível geração de renda.

Segundo Ellwanger e Fleck (2007 apud ZUCATTO; WELLE; SILVA, 2013), os OGRF, quando separados e recolhidos voltam à cadeia produtiva como matériaprima para outros produtos. Entre as possibilidades de reciclagem estão: a glicerina, composição de tintas, massa de vidraceiro, produção de farinha básica para ração 
animal, geração de energia elétrica por meio da queima em caldeira e produção de Biodiesel.

Vale ressaltar que, dentre as possibilidades de reciclagem, está o sabão ecológico, que se configura como uma prática sustentável possível de ser realizada nos domicílios, sem necessidade de tecnologias industriais para a produção.

Dessa maneira, as pessoas que utilizam essa prática, além de diminuir os impactos ambientais provocados pelo descarte inadequado dos OGRF, têm a possiblidade de geração de renda a partir da venda do produto.

Para a fabricação do sabão ecológico, é necessária a junção de alguns ingredientes, sendo os OGRF a base do produto. A reação dos ingredientes (OGRF + Hidróxido ou Carbonato de Sódio - soda) é denominada de saponificação (ALLINGER, 1976).

Ressalta-se que, mesmo o sabão sendo biodegradável, é necessário seguir algumas recomendações da Agência Nacional de Vigilância Sanitária (ANVISA), que dispõe sobre produtos saneantes domissanitários:

[...] as substâncias ou preparações destinadas à higienização, desinfecção, desinfestação, desodorização, odorização, de ambientes domiciliares, coletivos e/ou públicos, para utilização por qualquer pessoa, para fins domésticos, para aplicação ou manipulação por pessoas ou entidades. (ANVISA, Res. ํㅡ 366, Art. $2^{\circ}$ )

Assim, para produzir um sabão ecológico que não provoque riscos à saúde e seja eficiente nos processos de higienização, o índice de saponificação, ou seja, a quantidade de soda que deve ser utilizada para reação, de acordo com a Resolução da ANVISA no 59 de 2010, deve enquadrar os valores de $\mathrm{pH}^{2}$ acima de 2 e abaixo de 11,5 .

É notório que, para a manipulação de produtos corrosivos, como é o caso da Soda Cáustica (um dos ingredientes da receita de sabão ecológico), são necessários alguns cuidados. Conforme instruções constantes do rótulo da soda cáustica, é indicado o uso de Equipamento de Proteção de uso Individual (EPI): luvas, aventais e máscaras, para evitar o contato direto com o produto. No Brasil, a

2 Conceito de pH: potência de hidrogênio que expressa a acidez, basicidade e alcalinidade em determinada solução. A escala de $\mathrm{pH}$ varia entre 0 e 14 (temperatura de $25^{\circ} \mathrm{C}$ ), sendo $\mathrm{pH}$ igual a $7=$ neutro; $\mathrm{pH}<7$ = ácido; $\mathrm{pH}>7=$ básico.

A conceituação foi retirada do Manual da Química e está disponível em: https://www.manualdaquimica.com/fisico-quimica/conceito-ph.htm. Acesso em 12 dez. 2019. 
Norma Regulamentadora (NR 6) é que dispõe sobre o uso dos EPI, de acordo com a Portaria do Ministério do Trabalho n 3.214, de 08 de junho de 1978.

Portanto, verificou-se que, para minimizar os impactos ambientais provenientes do descarte inadequado dos OGRF, existem várias maneiras de reaproveitamento e reciclagem do resíduo, porém, a maneira mais simples e que dispensa o uso de tecnologias industriais é a fabricação de sabão ecológico em barra. Dessa forma, manteve-se o foco nas teorias e práticas relacionadas ao sabão ecológico. 


\section{METODOLOGIA}

Esta seção apresenta o caminho percorrido para o desenvolvimento da pesquisa, as características, os instrumentos utilizados para a coleta de dados, o campo de pesquisa e a maneira como os dados coletados foram tratados, com o propósito de dar um panorama a respeito do desenvolvimento, bem como as etapas de construção do produto educacional.

\subsection{CARACTERIZAÇÃO DA PESQUISA}

A presente pesquisa foi desenvolvida tendo como base o rigor metodológico explanado por Philippi Jr. (2004, p. 980):

Toda pesquisa necessita de um método, e este deve estar claro e detalhado no trabalho científico, de forma a ser compreendido por outros leitores ou aprimorado e detalhado por outros pesquisadores, que podem eventualmente dar continuidade à pesquisa.

Como metodologia, utilizou-se da pesquisa-ação na qual há envolvimento do pesquisador e do pesquisado na resolução de um problema coletivo.

De acordo com Thiollent (1985, p. 14):

[...] é um tipo de pesquisa social com base empírica que é concebida e realizada em estreita associação com uma ação ou com a resolução de um problema coletivo e no qual os pesquisadores e os participantes representativos da situação ou do problema estão envolvidos do modo cooperativo ou participativo.

Para embasar a pesquisa, utilizou-se a revisão da literatura com enfoque em teorias específicas das áreas de educação, educação para a sustentabilidade e resíduos sólidos, mais especificamente as que tratam dos óleos e gorduras residuais de fritura.

As etapas de desenvolvimento desta pesquisa foram realizadas junto ao galpão da reciclagem do Município e na Escola Municipal de Educação Básica Julio Benedicto Mendes, na cidade de Ibaté/SP. Os primeiros contatos para o 
agendamento das visitas foram feitos via telefone. A visita ao galpão foi agendada para o dia 28 de março de 2019, data em que a pesquisadora esteve no local. $\mathrm{Na}$ E.M. Júlio Benedicto Mendes, foi agendada a primeira reunião com a equipe gestora para apresentação do projeto no dia 02 de abril de 2019. Neste dia, a pesquisadora adentrou a escola pela primeira vez, sendo recebida pelo Diretor e pela Coordenadora Pedagógica, e apresentou o projeto e suas etapas. O desenvolvimento da pesquisa constou com a participação de uma turma de vinte e um (21) alunos matriculados no $4^{\circ}$ ano do ensino fundamental I e seus respectivos pais e/ou responsáveis. Posteriormente, as etapas do projeto serão descritas mais detalhadamente.

O fluxograma a seguir apresenta as etapas relacionadas ao processo de desenvolvimento desta pesquisa: 
Figura 2 - Fluxograma: etapas de desenvolvimento da pesquisa
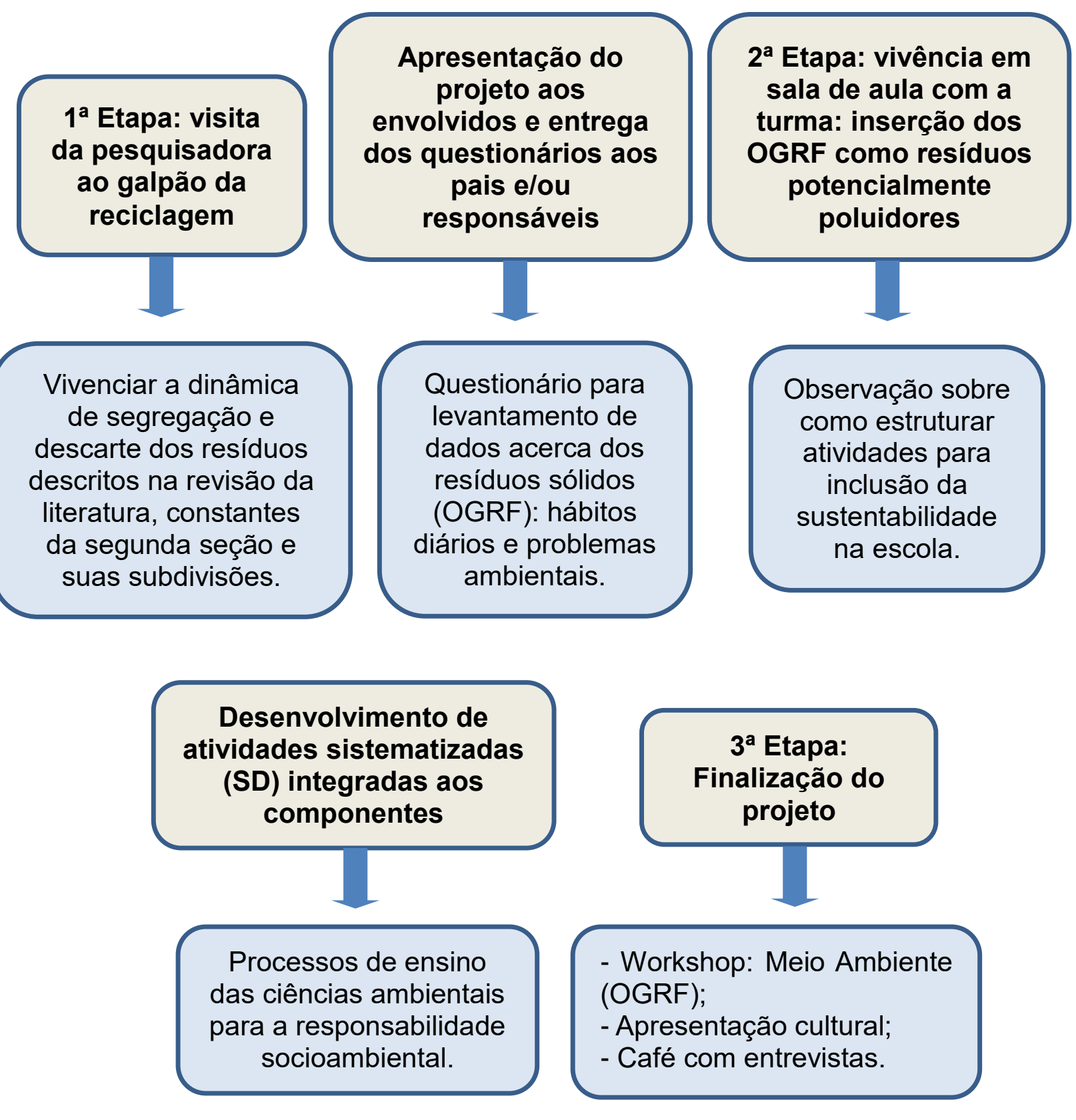

- Workshop: Meio Ambiente (OGRF);

- Apresentação cultural;

- Café com entrevistas.

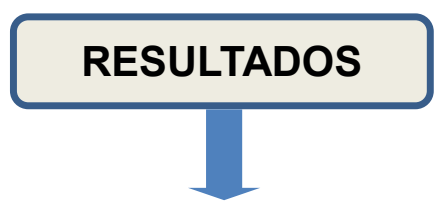

Análise da relevância da prática educacional por meio da SD; Tabulação dos resultados dos questionários;

Tabulação dos resultados das entrevistas.

Construção do produto educacional: cartilha contendo a SD como instrumento de ensino das ciências ambientais. 
Para a realização das etapas do projeto, no âmbito da E. M. Julio Benedicto Mendes, o tempo estimado foi de aproximadamente dois meses, com início em 02 de abril e término em 06 de junho de 2019. Ocorreram, em média, três encontros semanais com duração de 2 horas cada.

Dentre as etapas do projeto (vide fluxograma), para a coleta de dados dos pais e/ou responsáveis pelos alunos participantes do projeto de pesquisa, optou-se por um questionário formulado com questões subjetivas e entrevistas.

De acordo com Gil (2008, p.121):

Pode-se definir questionário como a técnica de investigação composta por um conjunto de questões que são submetidas a pessoas com o propósito de obter informações sobre conhecimentos, crenças, sentimentos, valores, interesses, expectativas, aspirações, temores, comportamento presente ou passado etc.

O questionário utilizado, conforme consta no Apêndice, foi aplicado com o objetivo de levantar os conhecimentos prévios acerca do uso, reciclagem e descarte dos óleos e gorduras residuais de fritura.

O uso das técnicas de entrevistas foi empregado ao término do projeto com intuito de avaliar o impacto desta pesquisa na vida dos envolvidos.

Em relação a entrevistas, Ribeiro (2008) as caracteriza como:

A técnica mais pertinente quando o pesquisador quer obter informações a respeito do seu objeto, que permitam conhecer sobre atitudes, sentimentos e valores subjacentes ao comportamento, o que significa que se pode ir além das descrições das ações, incorporando novas fontes para a interpretação dos resultados pelos próprios entrevistadores. (RIBEIRO, 2008, p. 141)

Ainda de acordo com Ribeiro (2008), as entrevistas são vantajosas pelo caráter flexível e adaptável durante a aplicação, podendo ser respondidas por pessoas alfabetizadas e não alfabetizadas.

Dentre as ferramentas, optou-se pelo uso de entrevistas abertas com propósito de explorar o entrevistado, dando-Ihe liberdade para abordar o assunto e responder por meio de uma conversa de caráter informal (MINAYO, 1993).

Para a análise dos resultados do questionário e das entrevistas, foi utilizada a abordagem qualitativa, que possibilita tratar os depoimentos dos envolvidos 
concernentes a vivências, percepções, sentimentos e demais dados que não são mensuráveis por meio de números.

Assim, a análise de dados, para Marconi e Lakatos (2008, p. 269), pelo método qualitativo:

[...] difere do quantitativo não só por não empregar instrumentos estatísticos, mas também pela forma de coleta e análise dos dados. A metodologia qualitativa preocupa-se em analisar e interpretar aspectos mais profundos, descrevendo a complexidade do comportamento humano.

Vale ressaltar que as entrevistas fizeram parte de um workshop ${ }^{3}$ que foi realizado na semana do meio ambiente, para finalizar o trabalho na unidade escolar.

Segundo Scarpa (2015), o Workshop constitui-se num ambiente abundante em conhecimentos, que possibilita interações entre os participantes.

Ainda, no decorrer do trabalho de campo, optou-se pelo registro fotográfico, realizado durante a visita ao galpão da coleta seletiva do Município e atividades desenvolvidas no ambiente escolar.

A etapa inicial desta pesquisa envolve o desenvolvimento de um projeto intitulado: Impactos Ambientais provocados pelos óleos e gorduras residuais de fritura e alternativas sustentáveis para o resíduo. Para o desdobramento do projeto, utilizou-se dos seguintes procedimentos:

\section{Etapa:}

Visita da pesquisadora ao Galpão da reciclagem;

a) registro fotográfico;

No âmbito escolar:

a) apresentação da pesquisadora e do projeto aos alunos;

b) entrega dos questionários endereçados aos pais e/ou responsáveis com o objetivo de levantar dados sobre uso, reciclagem e descarte dos óleos e gorduras residuais de fritura (OGRF);

c) roda de conversa com os alunos: momento de diálogo entre a

\footnotetext{
3 Segundo o dicionário Online de Português, a palavra Workshop significa: curso ou seminário intensivo, de pouca duração, em que habilidades artísticas ou intelectuais são exercidas. Disponível em: https://www.dicio.com.br/workshop/ Acesso em: 10 jan.2020.
} 
pesquisadora, alunos e professora, na qual foi possível ter um norte para a concepção da SD com o objetivo de inserir os resíduos sólidos, em específico os OGRF, como problema de ordem ambiental e seus impactos;

d) participação da pesquisadora na reunião de pais da escola, para um diálogo sobre o projeto em questão, com o objetivo de pedir 0 envolvimento e participação dos pais;

e) aplicação de atividades sistematizadas (em sala de aula) integradas às disciplinas do currículo, de acordo com a grade de horários e disponibilidade da professora;

\section{2a Etapa}

a) recolhimento dos questionários para tabulação dos dados;

b) roda de conversa para dialogar sobre as práticas utilizadas nos domicílios dos alunos;

c) analisar a relevância das atividades sistematizadas no processo de sensibilização dos participantes por meio do diálogo;

d) ensaio dos alunos para uma apresentação cultural (dentro da temática), se possível, na semana do meio ambiente, com o objetivo de trazer os pais e/ou responsáveis para a escola;

\section{3a Etapa}

a) workshop: Meio Ambiente - Resíduos Sólidos (OGRF);

b) apresentação cultural;

c) palestra sobre os resíduos sólidos, especificamente os OGRF; apresentação do panorama do galpão de reciclagem do Município para fomentar alternativas sustentáveis para os OGRF;

d) momento das entrevistas com os pais e/ou responsáveis com o objetivo de analisar o impacto do projeto para a responsabilidade socioambiental;

e) entrega de uma amostra e receita do sabão ecológico em barra; 
f) divulgação do ponto de coleta de OGRF junto à E. M. Julio Benedicto Mendes.

Após a trajetória citada acima, momento de tabulação e organização da coleta de dados, partiu-se para a escrita dos resultados obtidos durante todo o processo.

Por se tratar de uma pesquisa desenvolvida junto a um programa de Mestrado Profissional, a elaboração de um produto é requisito parcial para obtenção do título de Mestre. Nesse sentido, foi produzida uma cartilha educativa contendo a sequência didática desenvolvida durante a aplicação do projeto na escola, e sua utilização tem como intuito fomentar outros profissionais na inserção da sustentabilidade no âmbito escolar e/ou outros espaços possíveis.

\subsection{CAMPO DE PESQUISA}

Para o presente estudo, optou-se por desenvolver as atividades em um estabelecimento público municipal de ensino fundamental I, localizado no município de Ibaté - SP. De acordo ao Instituto Brasileiro de Geografia e Estatística (IBGE), estima-se que o Município seja habitado por cerca de 35.104 mil pessoas (2019).

Para compor o trabalho, houve a necessidade de integrar a visita ao galpão da coleta seletiva da cidade a fim de analisar as práticas e relações com os cidadãos da localidade.

A escolha da referida escola deu-se pela facilidade de acesso, por se tratar de uma instituição de ensino que faz parte da rede municipal na qual a pesquisadora atua como docente, e pela aceitação e disposição dos gestores em contribuir para a realização desta pesquisa. Vale ressaltar que não foi possível desenvolver a pesquisa junto à escola na qual a pesquisadora atuou em 2019 por motivo de níveis de ensino.

O ano/série foi escolhido mediante os conteúdos e componentes curriculares a serem trabalhados, de acordo a BNCC, e que se relacionam com o tema da pesquisa.

A E. M. Julio Benedicto Mendes está localizada no centro da Cidade, porém, por meio do transporte escolar gratuito, recebe alunos de diversos bairros do município. Atende 230 crianças, especificamente, do ensino fundamental I, de $1^{\circ}$ ao 
$5^{\circ}$ ano, ano/série que compõem o ensino fundamental de 9 anos, nos períodos matutino e vespertino, cujo horário de funcionamento é: das $07 h 30$ às $12 \mathrm{~h} 30$ e das $13 \mathrm{~h}$ às $18 \mathrm{~h}$, de segunda a sexta-feira.

Nesse nível de ensino (fundamental I), os componentes curriculares são trabalhados pelo (a) pedagogo(a), professor polivalente, exceto nas disciplinas de educação física e música, que exige conhecimentos de profissional especialista.

A gestão da escola é composta por um diretor e uma coordenadora pedagógica.

A estrutura física da escola conta com: 11 salas de aula, nas quais são atendidos, em média, 20 alunos por sala; laboratório de informática; sala de leitura; sala de recursos multifuncionais para atendimento educacional especializado (AEE); quadra de esportes coberta; área verde; refeitório; pátio coberto; além da acessibilidade para facilitar o acesso aos alunos com mobilidade reduzida.

Quanto aos recursos materiais, a escola possui televisão, aparelho de som, copiadora, impressora e projetor multimídia, facilitando o trabalho docente.

Em relação à alimentação, a escola oferece: café da manhã e almoço para os alunos do período matutino; e almoço e café da tarde para os alunos do período vespertino.

O ambiente escolar é agradável e os gestores mostram-se bastante empenhados em colaborar para a promoção de uma educação integral aos alunos.

Além do ambiente escolar, foi necessário visitar o Galpão de Reciclagem do Município para melhor entendimento dos processos de funcionamento (dinâmica de segregação e descarte dos resíduos sólidos e relação com o cidadão ibateense). 0 Galpão está localizado no antigo prédio do matadouro da Cidade, no bairro Jd. Icaraí, entre um terreno baldio e uma creche municipal. O Galpão conta com 2 funcionários diretos da prefeitura para a coleta seletiva com o caminhão gaiola e outras 5 mulheres que fazem parte de uma cooperativa. Ao todo são 7 funcionários que operam no galpão da reciclagem. 


\section{RESULTADOS E DISCUSSÕES}

Esta seção apresenta os resultados e discussões sobre o desenvolvimento deste trabalho, e foi dividido em subseções para melhor entendimento dos processos constantes desta pesquisa.

\subsection{CONCEPÇÃO DA SEQUÊNCIA DIDÁTICA}

A pesquisa foi desenvolvida por meio da utilização da metodologia de pesquisa-ação. Nesse sentido, quando a pesquisadora adentrou a sala de aula, as atividades sistematizadas (SD) não estavam prontas para serem desenvolvidas junto aos alunos; existia apenas uma ideia. Ao longo da roda de conversa entre a pesquisadora, alunos e professora regente da sala, foram-se estruturando as atividades a partir dos conhecimentos prévios dos alunos e baseadas no Currículo dos componentes de: Língua portuguesa, Arte, Geografia e Matemática.

$\mathrm{Na}$ sequência, seguem informações sobre os componentes curriculares perpassados pela temática OGRF com o objetivo de inserir a sustentabilidade na escola.

Segundo a BNCC (2017), dentre as competências específicas na área de Linguagens e Códigos (Língua Portuguesa e Arte) para o ensino fundamental, destaca-se:

Utilizar diferentes linguagens para defender pontos de vista que respeitem o outro e promovam os direitos humanos, a consciência socioambiental e o consumo responsável em âmbito local, regional e global, atuando criticamente frente a questões do mundo contemporâneo. (BRASIL, 2017, p. 65)

Considerando a dinâmica da Base Nacional Comum Curricular, é necessário o desenvolvimento de várias habilidades para que o aluno desenvolva uma determinada competência. Nesse sentido, os OGRF são temáticas pertinentes para o ensino das ciências ambientais e desenvolvimento de competências.

Para desenvolver a competência leitora e escritora no componente curricular de Língua Portuguesa, são necessárias algumas habilidades. Sendo assim, a 
sequência didática foi elaborada com intuito de desenvolver habilidades como: ler e compreender; planejar e produzir textos; escuta atenta, dentre outras.

No componente curricular de Arte, a BNCC o aborda a partir de quatro linguagens: artes visuais, dança, música e teatro. Dentre as várias competências está:

Desenvolver a autonomia, a crítica, a autoria e o trabalho coletivo e colaborativo nas artes. (BRASIL, 2017, p.198)

Dessa forma, quanto a este componente, procurou-se inserir a sustentabilidade na escola a partir do desenvolvimento de habilidades como: criação em artes visuais, formas de orientação no espaço e construção do movimento dançado.

Quanto à área de Matemática e suas Tecnologias, no componente curricular de matemática, destacam-se as competências abaixo:

Compreender as relações entre conceitos e procedimentos dos diferentes
campos da Matemática (Aritmética, Álgebra, Geometria, Estatística e
Probabilidade) e de outras áreas do conhecimento, sentindo segurança
quanto à própria capacidade de construir e aplicar conhecimentos
matemáticos, desenvolvendo a autoestima e a perseverança na busca de
soluções. Desenvolver e/ou discutir projetos que abordem, sobretudo, questões de urgência social, com base em princípios éticos, democráticos, sustentáveis e solidários, valorizando a diversidade de opiniões de indivíduos e de grupos sociais, sem preconceitos de qualquer natureza. (BRASIL, 2017, p. 267)

Por meio das competências descritas acima, buscou-se inserir a sustentabilidade na área de Matemática por meio de habilidades como: ler e escrever números naturais; relações entre a multiplicação e estratégia de cálculo; e medir, comparar e estimar área de figuras planas.

Em relação à área de Ciências Humanas e suas Tecnologias, no componente curricular de Geografia, destacam-se as competências: 
Identificar, comparar e explicar a intervenção do ser humano na natureza e na sociedade, exercitando a curiosidade e propondo ideias e ações que contribuam para a transformação espacial, social e cultural, de modo a participar efetivamente das dinâmicas da vida social.

Construir argumentos, com base nos conhecimentos das Ciências Humanas, para negociar e defender ideias e opiniões que respeitem e promovam os direitos humanos e a consciência socioambiental, exercitando a responsabilidade e o protagonismo voltados para o bem comum e a construção de uma sociedade justa, democrática e inclusiva. (BRASIL, 2017, p. 357)

Por meio do tema OGRF (TCTs), procurou-se desenvolver as habilidades: identificação de paisagens naturais e antrópicas (solo); e ação humana de conservação ou degradação do meio ambiente.

Para compor a SD foi escolhida a música: Terra, Planeta Água, de Guilherme Arantes, e o Filme: Um plano para salvar o Planeta, de Maurício de Souza. A escolha da música e do filme se deu por meio da verificação das palavras e imagens que, de acordo com a faixa etária das crianças, possuem linguagem e imagens adequadas.

Vale ressaltar que os componentes curriculares foram trabalhados de maneira interdisciplinar e transversal, permeando todas as disciplinas citadas, com propósito de despertar a responsabilidade socioambiental no espaço escolar e comunidade.

\subsection{VISITA AO GALPÃO DA RECICLAGEM DO MUNICÍPIO DE IBATÉ - SP}

A primeira etapa do projeto foi desenvolvida a partir da visita ao galpão da reciclagem para melhor compreensão dos processos de funcionamento (Figura 2).

Por meio da utilização da ferramenta entrevista foi possível levantar os seguintes dados: o galpão começou a operar há 11 anos, no dia 07/07/2008. As cinco (5) funcionárias que ali trabalham hoje, eram catadoras de materiais recicláveis no aterro. Por força de Lei foram proibidas de permanecerem lá; então, a Prefeitura ofereceu o Galpão, dois (2) caminhões gaiolas, dois (2) funcionários da Prefeitura para realizar a coleta seletiva nos bairros, e o pagamento de todas as despesas do galpão. Os salários das funcionárias cooperadas são obtidos por meio da venda dos materiais recicláveis. 
A coleta seletiva é realizada nos seguintes bairros: Centro, São Benedito, Santa Terezinha e Jardim Menzani, uma (1) vez por semana em cada bairro. Nos bairros: Jardim Icaraí, Jardim Cruzado, Popular e Companhia de Desenvolvimento Habitacional e Urbano do Estado de São Paulo (CDHU), a coleta fica por conta dos catadores individuais.

O Galpão recebe resíduos de plásticos, metais, alumínio, papelão, vidro e óleos e gorduras residuais de fritura (OGRF).

Nos bairros onde existe a coleta seletiva, o funcionário que faz o serviço deixa sacos grandes (bags) nas residências e, depois, passa para retirá-los. Dentro das bags têm todo tipo de material reciclável. Ao chegar ao galpão, o material é passado por uma triagem para separação dos resíduos, conforme a sua composição, e, depois, são prensados para, posteriormente, serem vendidos. Os OGRF são recebidos em garrafas pet, vidros de margarina, vidros de alimentos em conserva, entre outros potes de vidro ou de plástico com tampa. Quando chegam ao galpão, os OGRF são despejados num tambor e, posteriormente, são vendidos para uma empresa fabricante de ração animal.

No momento da visita, recebeu-se a informação de que o galpão coleta, mensalmente, entre 30 e 40 litros de OGRF.

Vale ressaltar que, dentre os resíduos sólidos, os OGRF são objetos e foco desta pesquisa, porém, foi realizado um levantamento dos resíduos sólidos recicláveis em geral para dar visibilidade ao trabalho do galpão e, possivelmente, aumentar a renda das mulheres cooperadas, uma vez que, quanto mais resíduos forem recolhidos, maior será a renda delas e, consequentemente, menos impactos ambientais serão provocados pelo descarte incorreto.

Fomentar a segregação dos materiais e entrega ao galpão é um trabalho essencial para minimizar os impactos ambientais contribuindo para a geração de renda das mulheres cooperadas, além de exercer a responsabilidade socioambiental. 
Figura 3 - Galpão da reciclagem, triagem e separação dos materiais recicláveis e tambor coletor de OGRF

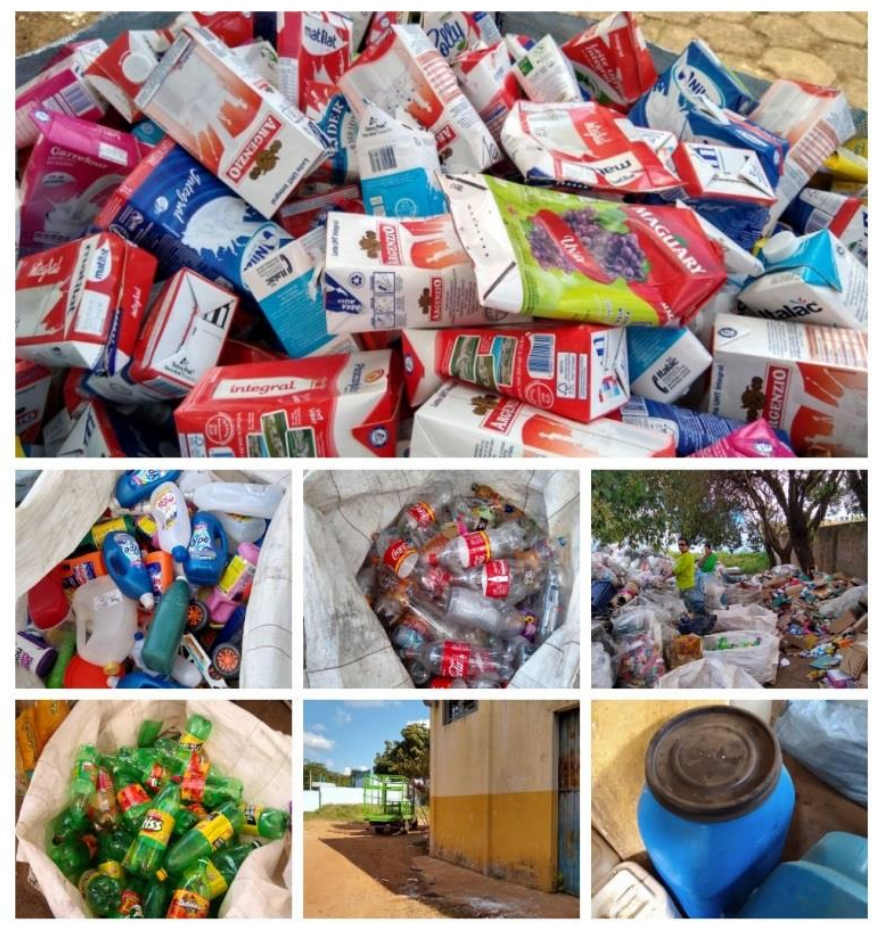

Fonte: Arquivo da pesquisadora (2019).

\subsection{DETALHAMENTO DAS ATIVIDADES TRABALHADAS DURANTE A APLICAÇÃO DO PROJETO}

No âmbito da E.M. Júlio Benedicto Mendes, a pesquisadora adentrou, pela primeira vez, no dia 02 de abril de 2019 para apresentação do projeto à gestão: direção, coordenação e professora regente do $4^{\circ}$ ano. Após a permissão para realização do projeto foram desenvolvidas as práticas abaixo relacionadas:

Tema: Impactos ambientais provocados por óleos e gorduras residuais de fritura e alternativas sustentáveis para o resíduo;

1ªtapa: Apresentação do Tema e levantamento dos conhecimentos prévios dos alunos (Figuras 4, 5 e 6).

* Inserção do resíduo de óleo de fritura como poluente do ar, água e solo;

- levantamento das práticas domésticas;

- reciclagem e descarte do resíduo; 
- filme: Um plano para salvar o Planeta, de Maurício de Souza;

- diálogo para compartilhar os problemas ambientais relatados no filme

- entrega do questionário aos alunos, que o encaminhariam para os pais e/ou responsáveis.

Figura 4 - Sala de aula - $4^{\circ}$ ano - apresentação do Tema

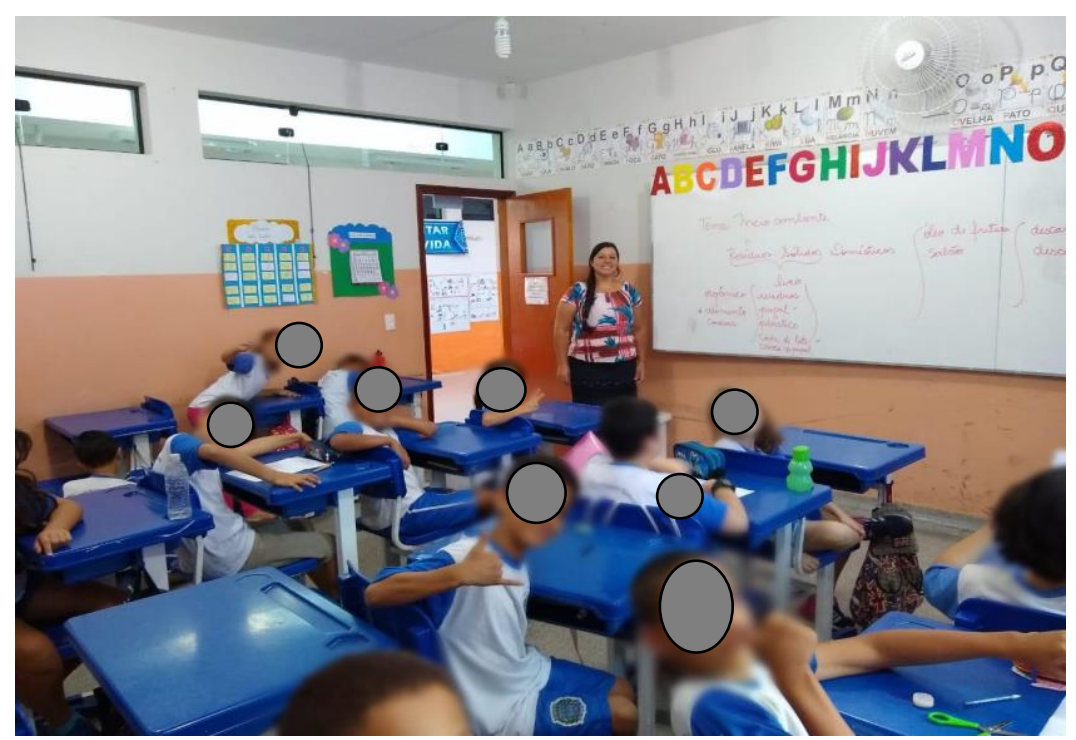

Fonte: Arquivo da pesquisadora (2019). 
Figura 5 - Entrega dos questionários

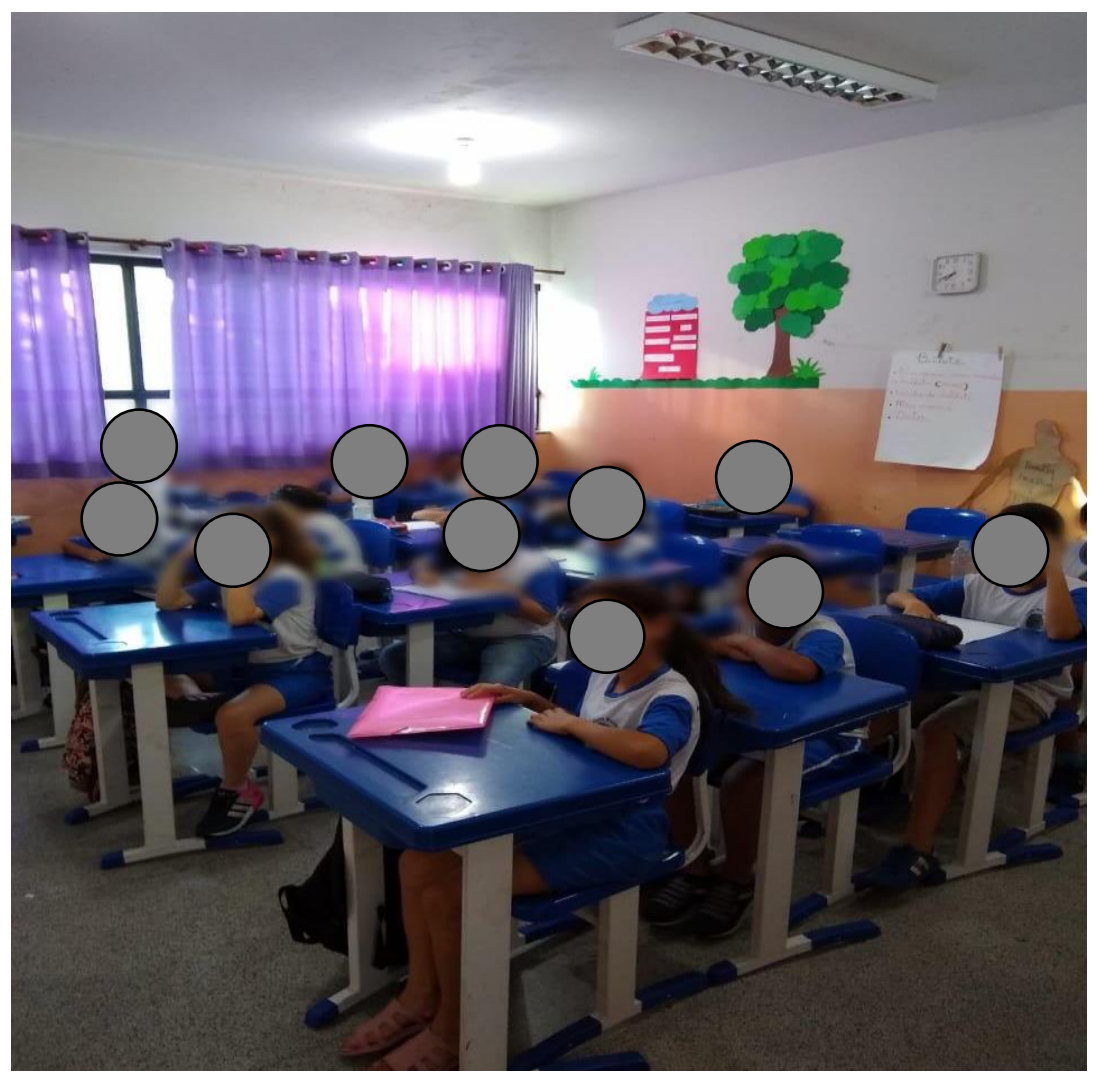

Fonte: Arquivo da pesquisadora (2019).

Figura 6 - Sala de vídeo - Filme: Um plano para salvar o Planeta, de Maurício de Sousa.

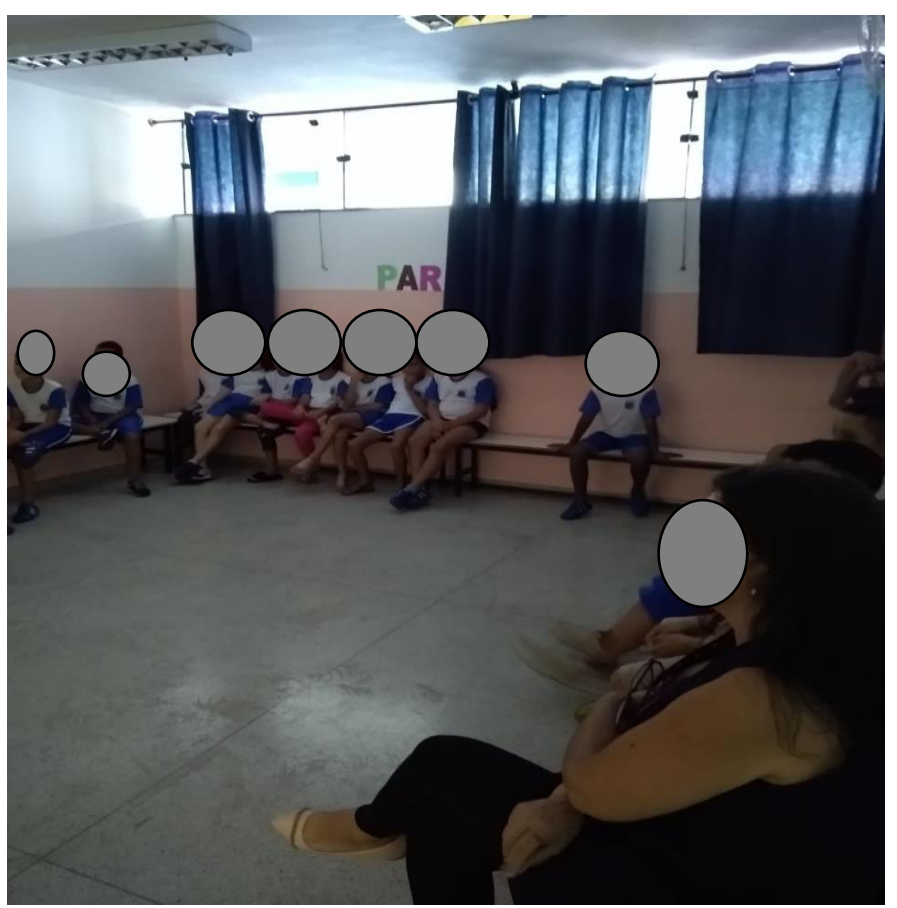

Fonte: Arquivo da pesquisadora (2019). 
Após a realização das ações descritas, foi oportunizado à pesquisadora participar da reunião de Pais e Mestres. Durante a reunião, a professora regente da sala reservou cerca de 20 minutos para a pesquisadora apresentar o projeto aos pais e/ou responsáveis, explicar sobre o questionário que os alunos já haviam levado para casa e fomentar o envolvimento dos pais no projeto, de modo que os alunos e os pais pudessem dialogar sobre todo o processo, inclusive sobre as sequências de atividades (SD) direcionadas aos alunos, mas que foram estruturadas de acordo com o tema e competências a serem desenvolvidas pelos componentes curriculares, propostas pela BNCC (2017).

Os óleos e gorduras residuais de fritura (OGRF) são resíduos que fazem parte do dia a dia das residências e, em virtude disso, a participação dos pais foi fundamental para atingir os objetivos da pesquisa.

2a Etapa: Detalhamento das atividades práticas com enfoque interdisciplinar (Figuras: 7 e 8).

a) Área de Linguagens e Códigos (BNCC) - cujos componentes curriculares trabalhados foram: Língua Portuguesa e Arte;

Recurso: Música - Planeta água, de Guilherme Arantes (intérprete e compositor);

- Componente curricular: Língua Portuguesa

- Habilidades e competências de acordo com a BNCC (2017);

- Competência: leitora e escritora;

- Habilidades: ler e compreender; planejar e produzir textos; e escuta atenta.

\section{Práticas pedagógicas:}

- Leitura compartilhada e escuta da música;

- Identificação da ideia central da música;

- Produção de poesia sobre poluição ambiental: utilização de conceitos apresentados desde o início do trabalho (Figura 7 e 8). 
Figura 7 - Poesia: A terra com poluição

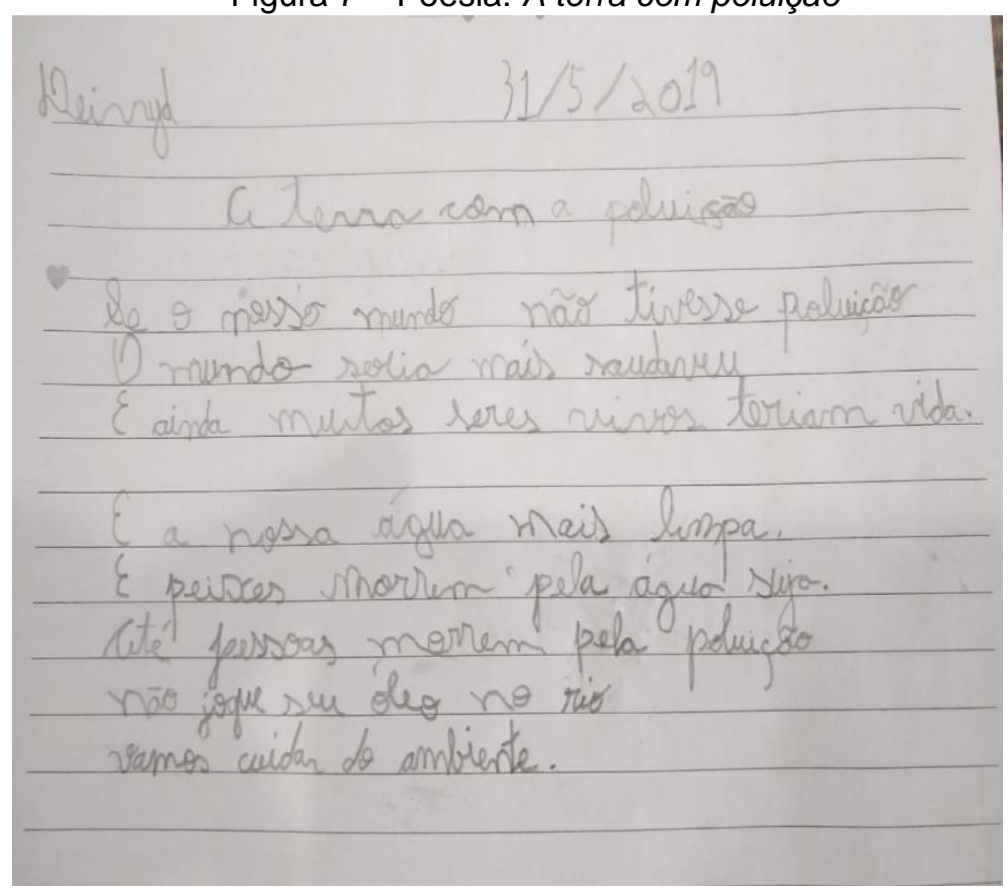

Fonte: Arquivo da pesquisadora (2019).

Figura 8 - Poesia: A poluição

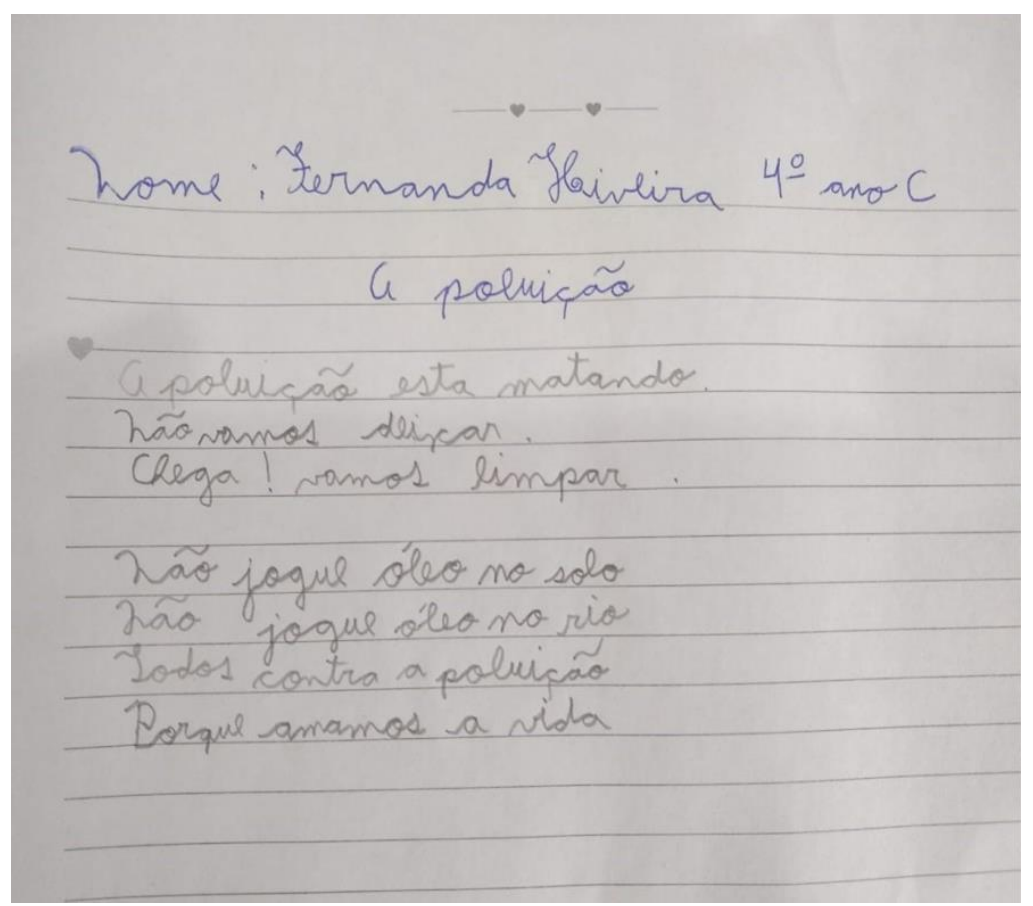

Fonte: Arquivo da pesquisadora (2019). 
- Componente curricular: Arte

- Habilidades e competências de acordo com a BNCC (2017);

- Competência: "Desenvolver a autonomia, a crítica, a autoria e o trabalho coletivo e colaborativo nas artes" (BRASIL, 2017, p.198);

- Habilidades: criação em artes visuais, formas de orientação no espaço e construção do movimento.

\section{Práticas pedagógicas desenvolvidas:}

- Representação da música por meio de desenho, valendo-se de tudo o que foi abordado durante todo o percurso do projeto;

- Representação da música por meio de dança coreografada - a dança foi apresentada aos pais, no Workshop, como composição das atividades do Dia Mundial do Meio Ambiente (05/06), vide figuras 9 e 10 .

Figura 9 - Representação artística da música: Terra, Planeta Água, de Guilherme Arantes.

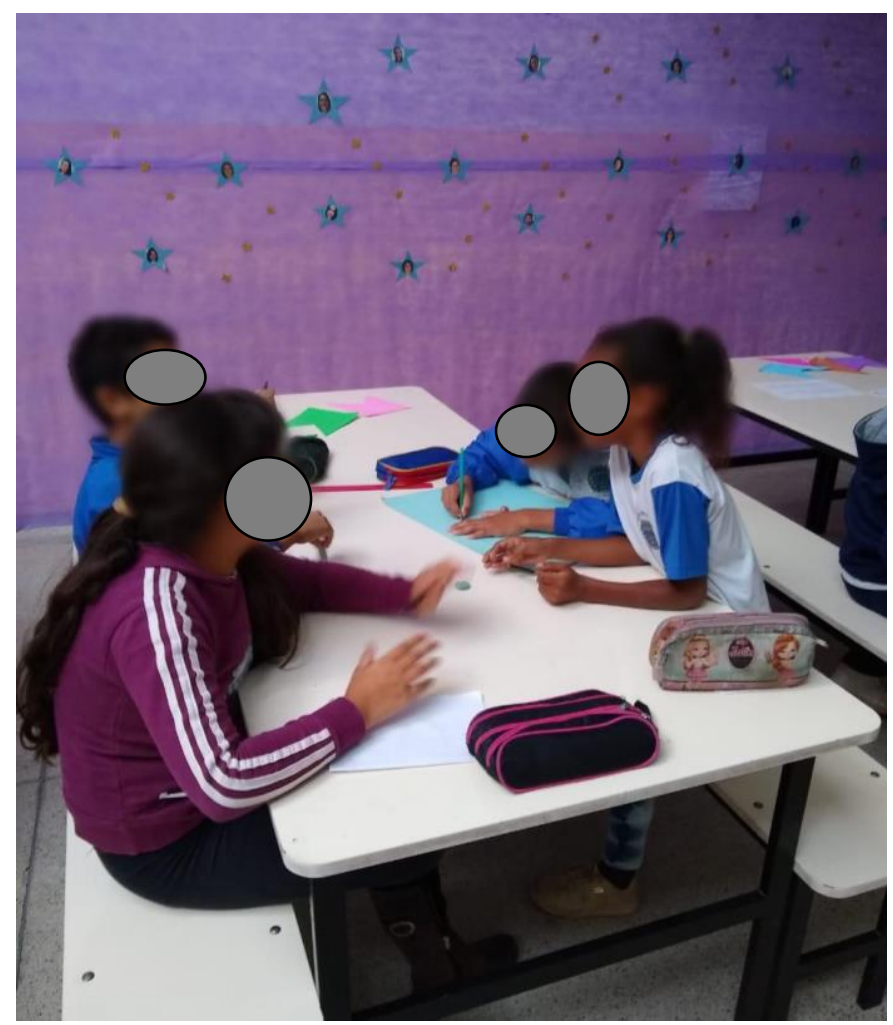

Fonte: Arquivo da pesquisadora (2019). 
Figura 10 - Workshop: Representação da música e dança coreografada

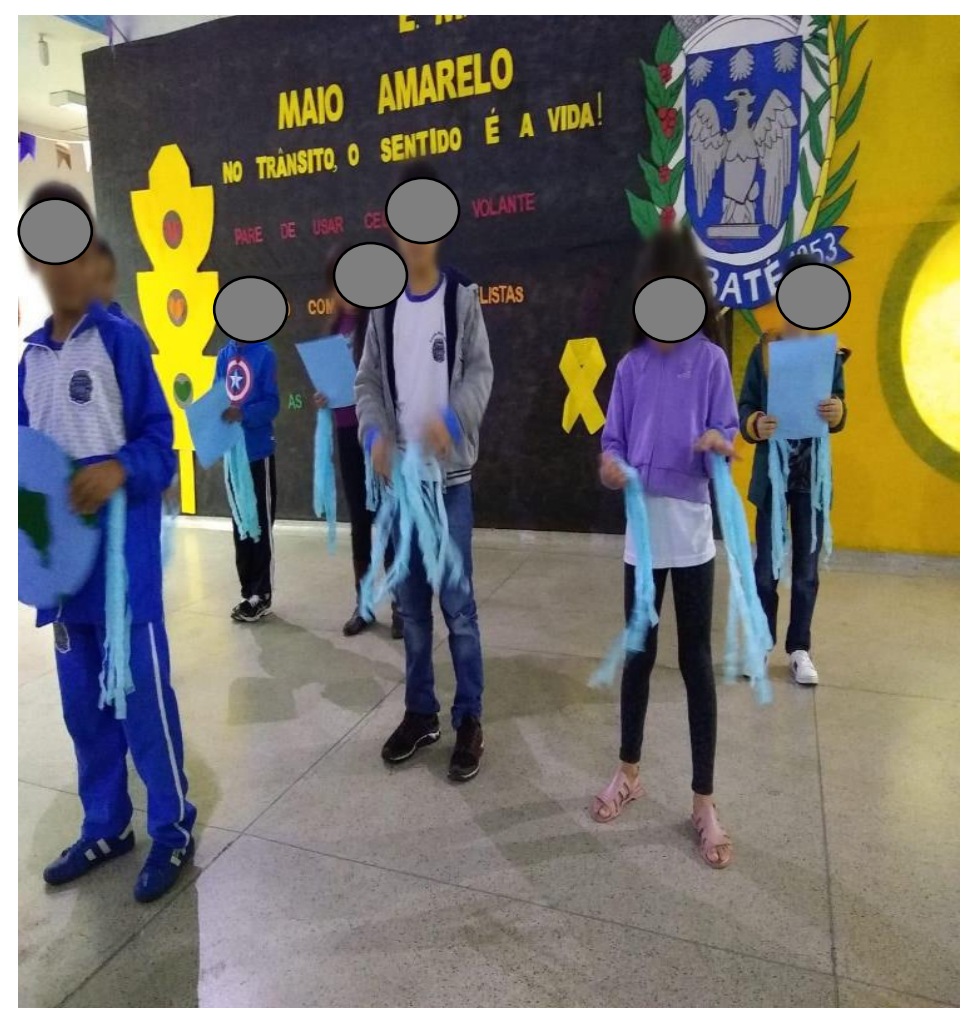

Fonte: Arquivo da pesquisadora (2019).

b) Área de Ciências Humanas

- Componente curricular: Geografia

- Habilidades e competências orientadas pela BNCC (2017);

- Competências:

Identificar, comparar e explicar a intervenção do ser humano na natureza e na sociedade, exercitando a curiosidade e propondo ideias e ações que contribuam para a transformação espacial, social e cultural, de modo a participar efetivamente das dinâmicas da vida social.

Construir argumentos, com base nos conhecimentos das Ciências Humanas, para negociar e defender ideias e opiniões que respeitem e promovam os direitos humanos e a consciência socioambiental, exercitando a responsabilidade e o protagonismo voltados para o bem comum e a construção de uma sociedade justa, democrática e inclusiva (BRASIL, 2017, p. 357).

- Habilidades: identificação de paisagens naturais e antrópicas (solo); e ação humana de conservação ou degradação do meio ambiente. 


\section{Práticas pedagógicas desenvolvidas:}

- Recurso: recipiente com amostra de solo, e resíduo de óleo de fritura;

- Conteúdos: conservação e degradação da natureza; fertilidade do solo; poluição e infertilidade do solo; perda de nutrientes.

- Desenvolvimento: utilizamos a amostra de solo para explanação da teoria e os alunos fizeram o experimento de poluição do solo por óleos e gorduras residuais de fritura (OGRF) para observarem a diferença entre um solo fértil e poluído e impermeabilização do solo (Figuras 10 e 11).

Figura 11 - Observação do solo fértil

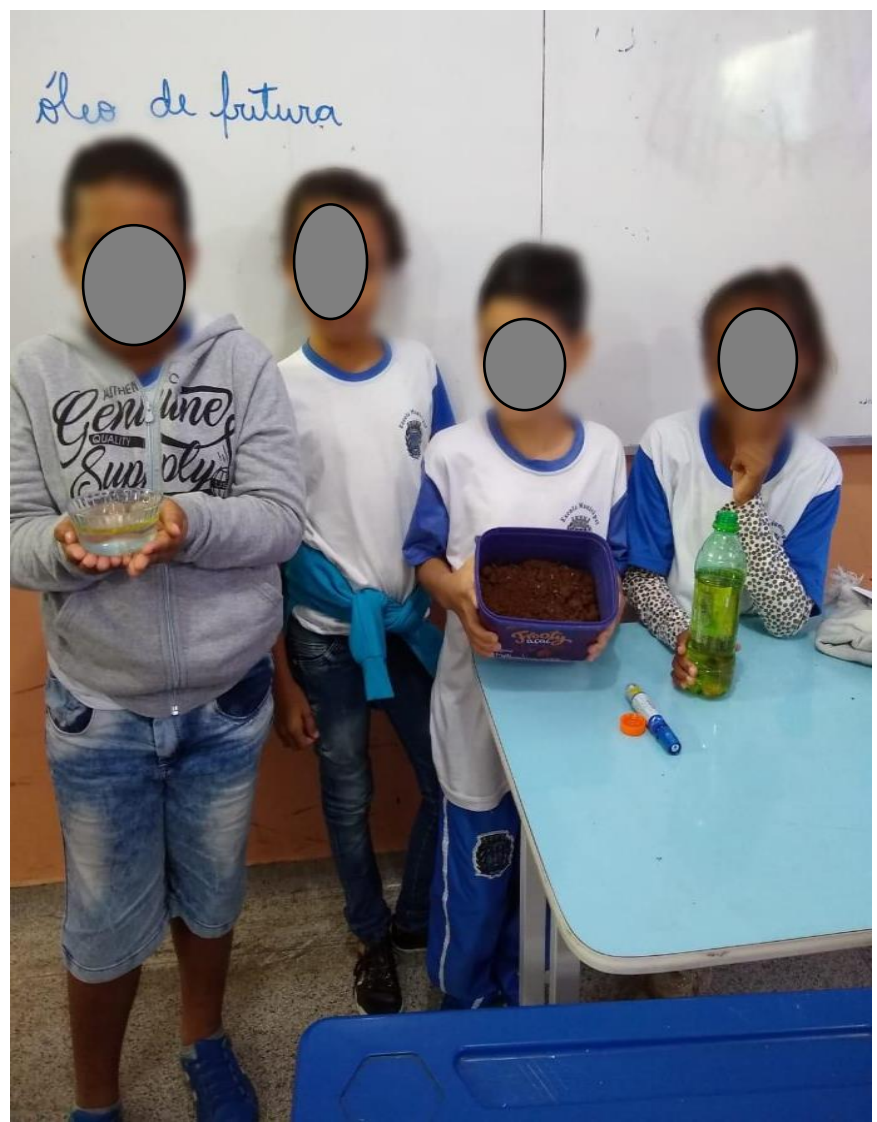

Fonte: Arquivo da pesquisadora (2019). 
Figura 12 - Solo sendo poluído pelos OGRF - observação da impermeabilização

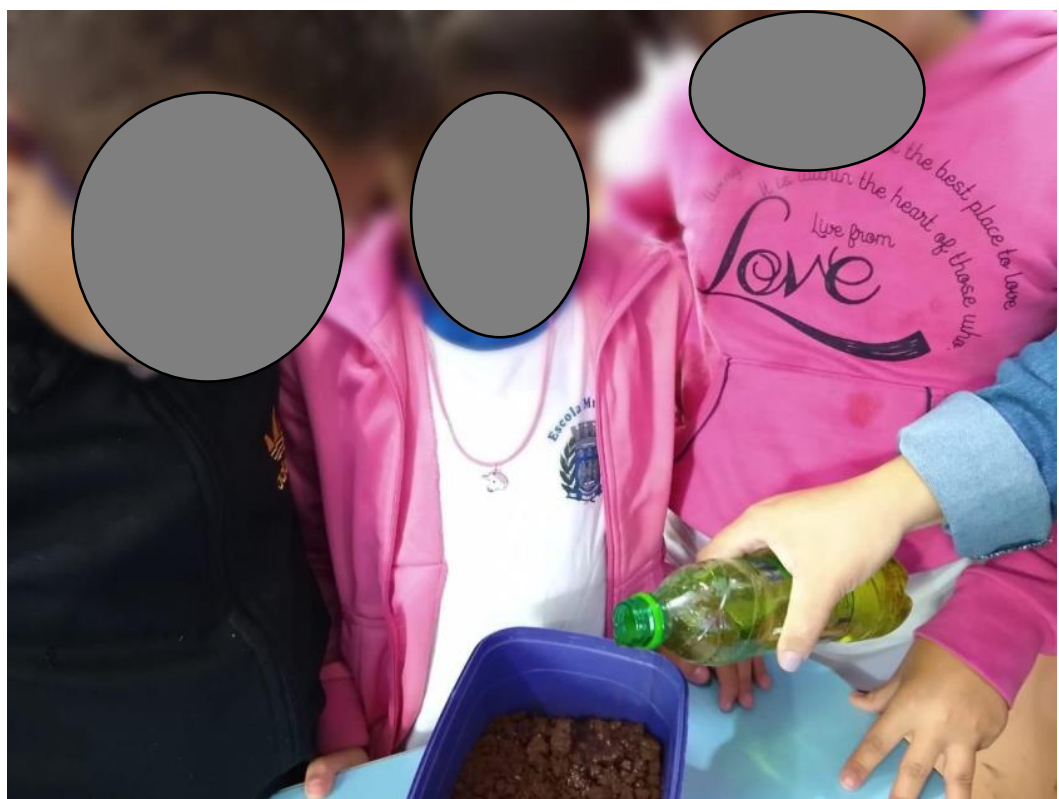

Fonte: Arquivo da pesquisadora (2019).

c) Área: Matemática

- Componente curricular: Matemática

Habilidades e competências de acordo com a BNN (2017);

- Competência:

Compreender as relações entre conceitos e procedimentos dos diferentes campos da Matemática (Aritmética, Álgebra, Geometria, Estatística e Probabilidade) e de outras áreas do conhecimento, sentindo segurança quanto à própria capacidade de construir e aplicar conhecimentos matemáticos, desenvolvendo a autoestima e a perseverança na busca de soluções.

Desenvolver e/ou discutir projetos que abordem, sobretudo, questões de urgência social, com base em princípios éticos, democráticos, sustentáveis e solidários, valorizando a diversidade de opiniões de indivíduos e de grupos sociais, sem preconceitos de qualquer natureza. (BRASIL, 2017, p. 267)

- Habilidades: ler e escrever números naturais; relações entre a multiplicação e estratégia de cálculo; e medir comparar e estimar área de figuras planas. 


\section{Prática pedagógica desenvolvida:}

- Recurso: o mesmo recipiente com amostra de solo utilizado na atividade de Geografia;

- Identificar a figura do recipiente;

- Cálculo da área do recipiente.

Vale ressaltar que, todas as atividades realizadas e descritas foram trabalhadas dentro dos componentes curriculares citados (de acordo a BNCC), por meio da interdisciplinaridade, ou seja, ao mesmo tempo em que foram abordadas as particularidades de cada componente curricular, eram enfatizadas as questões ambientais do tema em questão.

Durante o percurso do projeto, à medida da disponibilidade dos pais e/ou responsáveis, os alunos foram devolvendo os questionários respondidos. Foram entregues 21 questionários para os alunos matriculados e frequentes no $4^{\circ}$ ano, e todos os trouxeram respondidos.

Após a devolução dos questionários respondidos e realização das atividades sistematizadas (SD) com os alunos, a pesquisadora fez uma análise prévia da trajetória do projeto e realizou uma roda de conversa, em sala de aula, para debater os impactos produzidos na vida dos envolvidos por meio do desenvolvimento desta pesquisa. Os alunos participantes relataram que, em casa, não se pode mais despejar óleo no ralo, na pia ou na terra, porque os pais e eles aprenderam como devem proceder ao descartar o óleo. Por meio dos relatos feitos pelos alunos foi possível identificar o impacto positivo da inserção da sustentabilidade na escola e na comunidade por meio da sequência didática, uma vez que os alunos não só desenvolveram competências e habilidades constantes dos componentes curriculares, mas também vivenciaram a responsabilidade socioambiental, assim como seus responsáveis.

Por meio da aplicação do questionário, primeira etapa da coleta de dados junto aos pais e/ou responsáveis, foi possível identificar a origem dos óleos e gorduras utilizados nos domicílios dos participantes, o consumo mensal por domicilio, as práticas de descarte e a relação com o fator idade, ainda que a identidade do respondente tenha sido preservada. Foi relevante identificar a idade do respondente para, posteriormente, confrontar com as práticas. 
Foram distribuídos 21 questionários aos responsáveis pelos alunos do $4^{0}$ ano que, após terem sido respondidos, foram devolvidos à pesquisadora.

Por meio das respostas, identificou-se que $57,14 \%$ dos respondentes tinham idade entre 30 e 45 anos e 42,86\% tinham acima de 40 anos de idade; com relação à origem dos OGRF, 24\% utilizam gordura de origem animal, 43\%, vegetal e 33\% utilizam óleo vegetal ou gordura animal; após o uso, 19\% responderam que descartam na terra, $9 \%$, no ralo, e $29 \%$, na pia, totalizando $57 \%$ os que descartam os OGRF de maneira inadequada. Do restante das pessoas (43\%), 14\% segregam, acondicionam em recipientes e entregam a terceiros e $29 \%$ produzem sabão a partir dos resíduos. Vale ressaltar ainda que, de acordo com as respostas, os $29 \%$ que produzem sabão estão no grupo das pessoas que possuem 40 anos de idade ou mais. Infere-se que a produção de sabão, por ser uma prática antiga, acaba sendo utilizada por pessoas mais velhas. Em média, cada domicílio utiliza mensalmente entre 3 e 5 litros de óleos ou gorduras, considerando que, em cada uma residem entre 4 e 6 pessoas.

De acordo com os números apresentados nas respostas dos questionários, pode-se concluir que é alarmante a quantidade de pessoas que descartam os OGRF de maneira inadequada, sendo que, após o desenvolvimento do projeto, por meio de informações obtidas pela gestão da escola e pelos funcionários do galpão da reciclagem, houve mudanças de comportamento, pois, a escola passou a receber, mensalmente, em torno de 10 garrafas de $2 \mathrm{~L}$ e, no galpão da reciclagem, 15 litros a mais que o esperado mensalmente. É notório saber que 35 litros de OGRF desviados dos mananciais, solo e ar é um número ainda pequeno se considerarmos o número de habitantes do município de lbaté, SP. Porém, é essencial reconhecer que este é um indicador de mudanças de comportamento, apontando que houve sensibilização de pessoas com relação às questões ambientais. A sensibilização de pessoas por meio da educação é processual e os frutos são colhidos continuamente.

Por meio do desenvolvimento das etapas desta pesquisa percebeu-se que é fundamental desenvolver projetos que fomentem práticas sustentáveis durante todo o tempo, para que seja possível sensibilizar um maior número de pessoas para a responsabilidade socioambiental e, consequentemente, a minimização dos impactos ambientais produzidos pelos OGRF.

Para melhor visualização, seguem os resultados dos questionários em formato 
de gráficos (Figuras 13,14,15 e16).

Figura 13 - Origem do óleos utilizados nos domícilios

\section{Origem do óleo descartado}

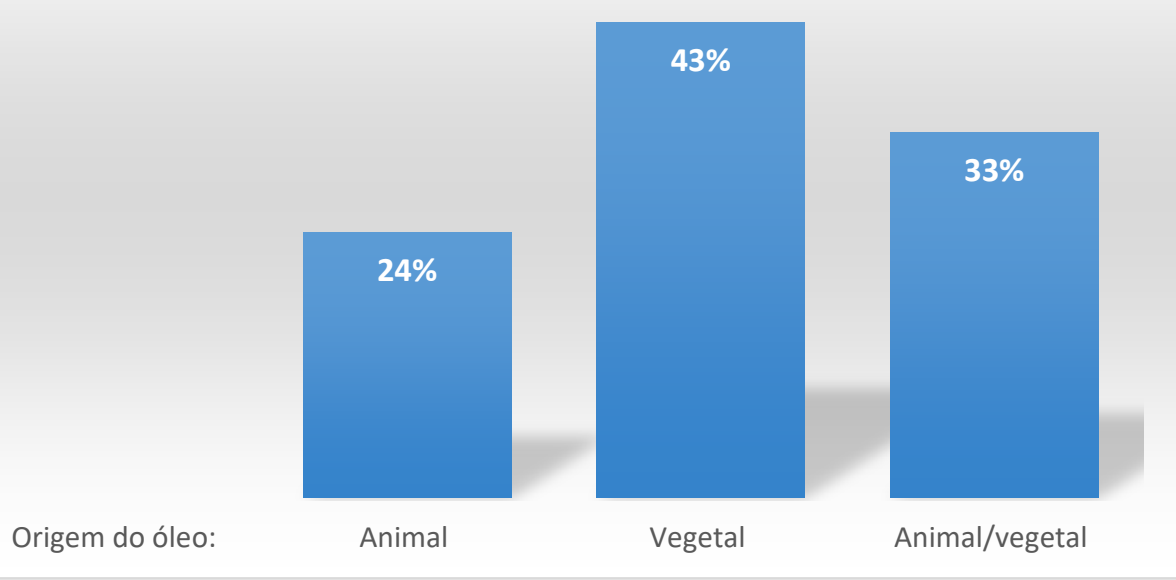

Fonte: Dados da pesquisa (2019).

Figura 14 - Consumo mensal de OGRF por domicílio

\section{Consumo mensal de OGRF}

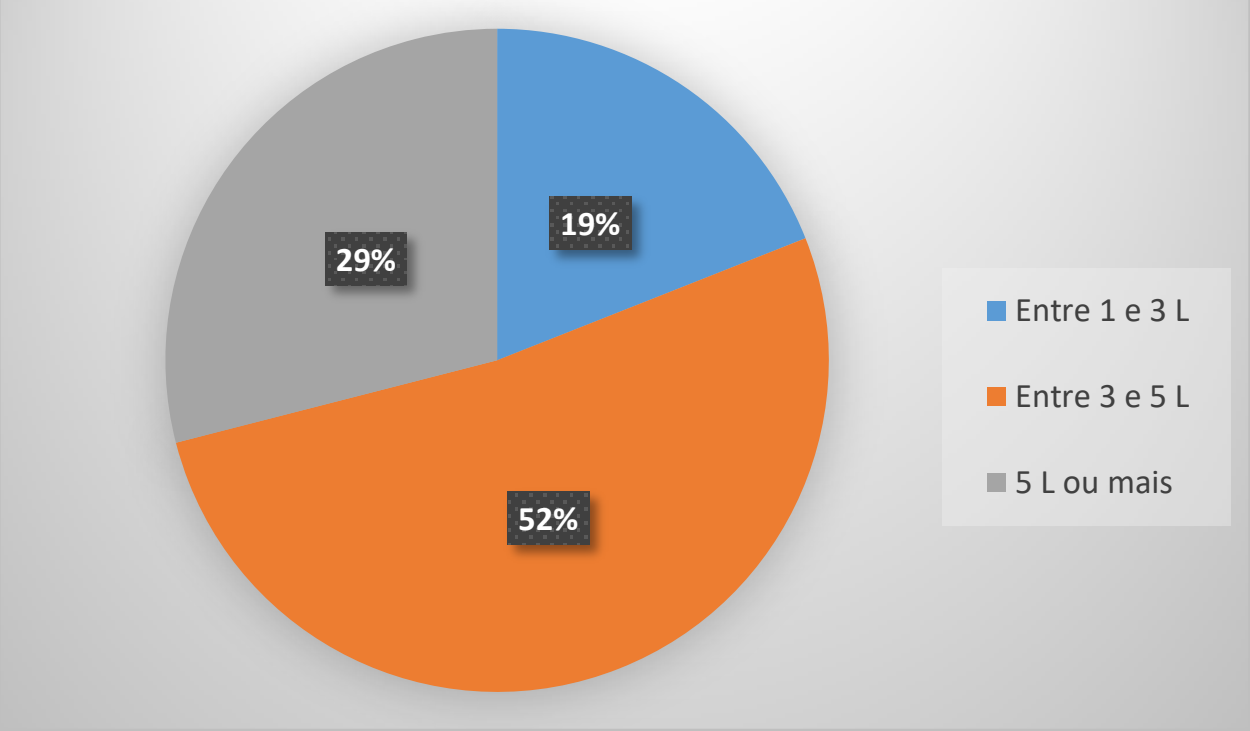

Fonte: Dados da pesquisa (2019). 
Figura 15 - Práticas mais utilizadas para descarte dos OGRF

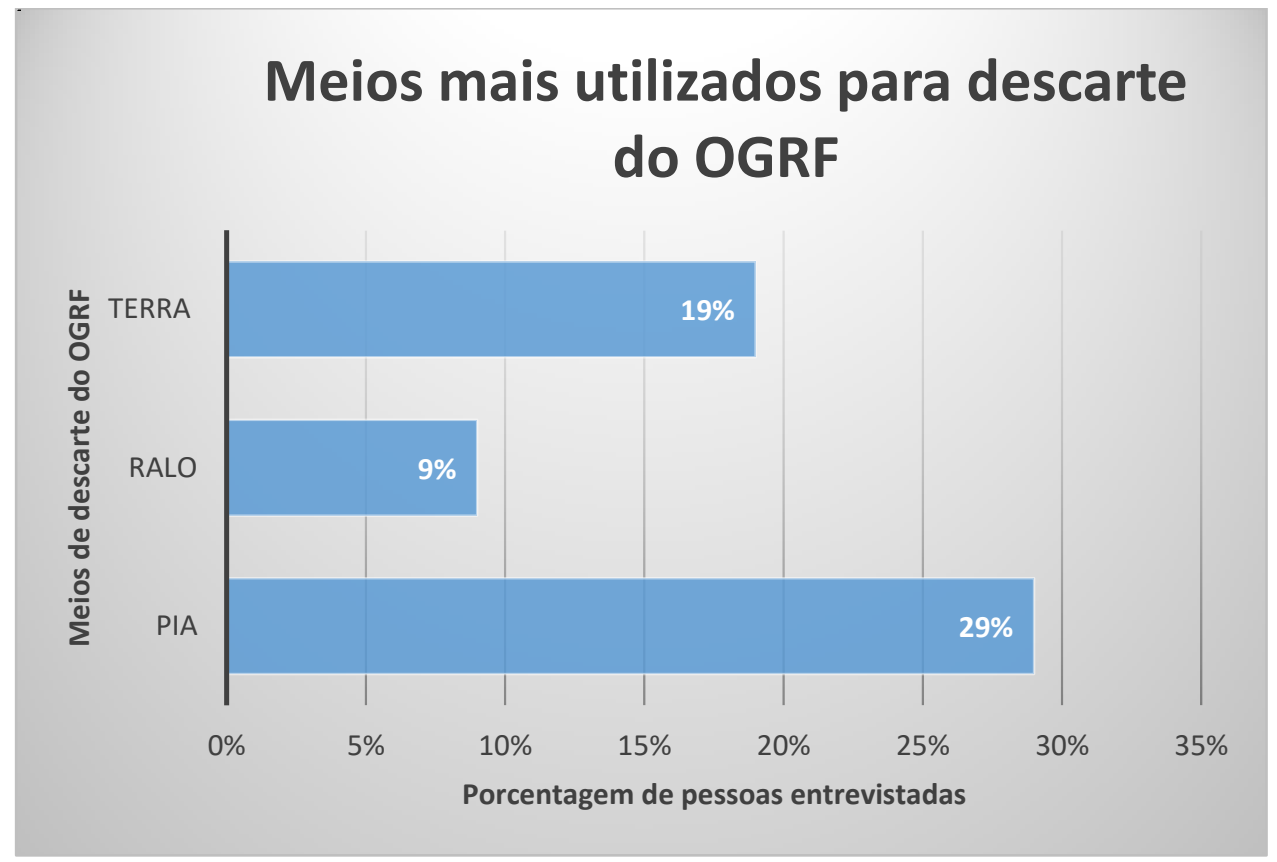

Fonte: Dados da pesquisa (2019).

Figura 16 - Idade dos respondentes do questionário

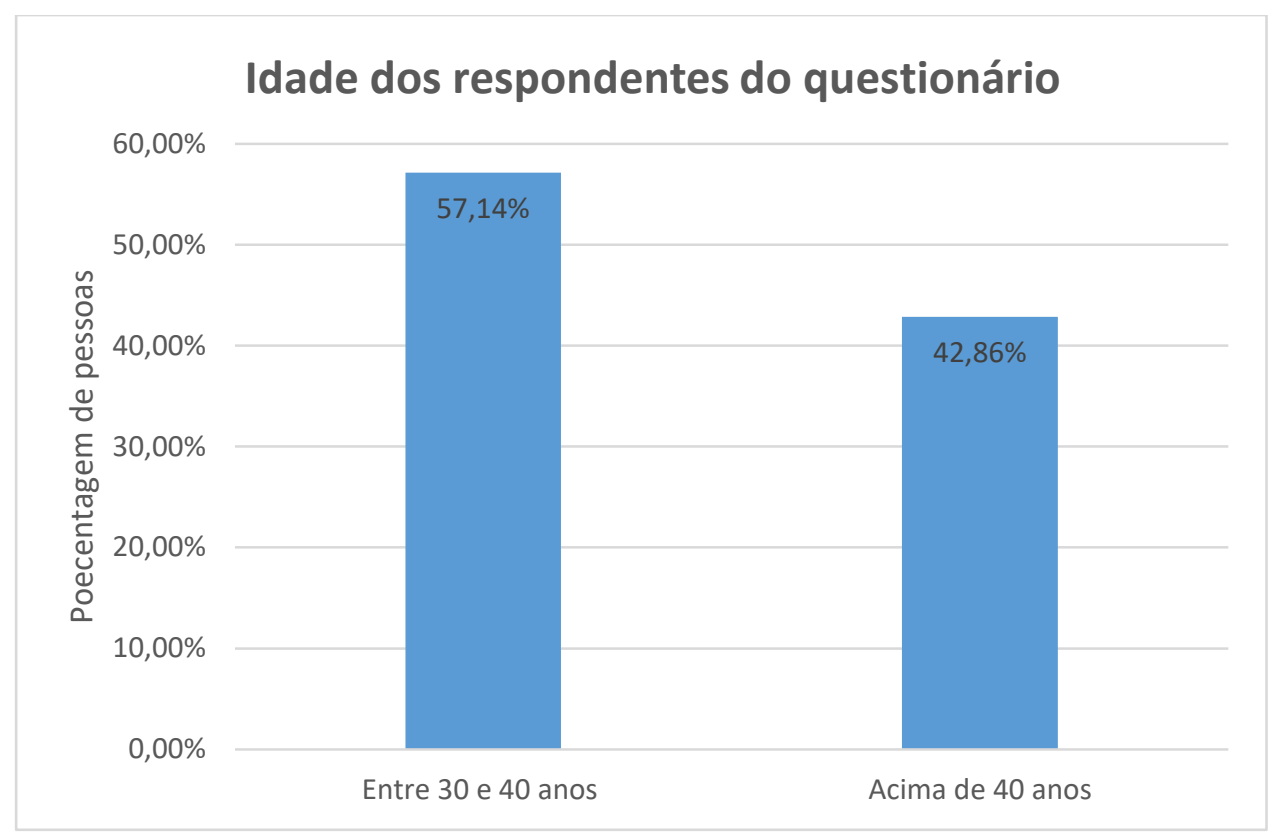

Fonte: Dados da pesquisa (2019). 
3a etapa - Workshop: Resíduos Sólidos - óleos e gorduras residuais de fritura. Apresentação Cultural - Dia Mundial do Meio Ambiente (05/06/2019).

Antes de descrever a apresentação cultural, é necessário enfatizar que, para trazer os pais e/ou responsáveis dos alunos à escola, foi necessário pensar em estratégias que despertassem o interesse deles.

Como já foi citado, as ações do projeto iniciaram-se pela visita ao galpão da reciclagem e em sala de aula com os alunos para apresentação da pesquisadora e do tema. Nesse primeiro momento em sala de aula, os alunos levaram o questionário acerca das práticas domésticas relacionadas ao óleo residual de fritura para os pais e/ou responsáveis responderem. Antes de iniciar a sequência didática foi possível que a pesquisadora participasse da reunião de pais e mestres e, dessa forma, fizesse a apresentação o projeto para os pais, a explicação do objetivo do questionário e pedisse o envolvimento e participação de todos nas atividades. No início da reunião, foi comunicado que haveria uma palestra ao final da aplicação do projeto.

Após essa apresentação, o projeto teve seu andamento com 0 desenvolvimento das atividades que compuseram a sequência didática. Durante as atividades, os alunos ficaram responsáveis por multiplicar os conhecimentos recebidos e/ou atualizados acerca da temática aos pais e/ou seus responsáveis. As rodas de conversas eram riquíssimas por possibilitar trocas de experiências e foram muito valiosas no sentido de impregnar na criança, desde cedo, o sentimento de pertencimento ao meio.

Por meio das rodas de conversas, ficou evidente que os pais e/ou responsáveis acompanharam e participaram do projeto, pois os alunos relataram que, quanto às práticas iniciais de descarte dos OGRF, à medida que eles multiplicavam os conhecimentos adquiridos e/ou atualizados na escola, em casa ocorriam mudanças de comportamentos por parte dos envolvidos no processo. Os alunos mencionaram ainda que acompanhavam os pais na hora da separação, reciclagem ou descarte dos OGRF e cobravam deles ações adequadas.

Dessa maneira, como estratégia para trazer os responsáveis para dentro da escola, no dia 05/06/2019, data em que foi realizado o Workshop, a coordenação entrou em contato, por telefone, com todos os pais ou responsáveis pelos alunos envolvidos com o projeto, convidando-os para assistirem a uma apresentação de 
dança das crianças e que, posteriormente, participariam de uma palestra sobre Resíduos Sólidos, parte do projeto já de conhecimento dos pais. A coordenadora avisou que os alunos estavam levando o convite com maiores detalhes e que, no final do evento, seria oferecido um café - momento em que a pesquisadora utilizou para realizar as entrevistas sobre os impactos do projeto no dia a dia dessas pessoas e analisar as mudanças de comportamentos pós-projeto.

Foi necessária toda essa articulação para trazer os pais e/ou responsáveis para a escola porque, de acordo com a coordenadora, a presença dos pais nas reuniões escolares é muito baixa. Sendo assim, foi preciso fomentar a participação deles no Workshop para obtenção de dados das entrevistas e finalização do projeto.

No Workshop, momento da palestra, foi apresentado, por meio de fotografias, todo o percurso do projeto no ambiente escolar; a visita ao galpão de coletiva seletiva e seus processos: história do início das atividades no galpão de reciclagem, funcionários que operam no local, informações sobre os dias da coleta seletiva nos bairros; e, especificamente, abordagem do manejo de resíduos sólidos domésticos, com foco maior nos óleos e gorduras residuais de fritura, impactos ambientais provocados por esses tipos de resíduos e alternativas sustentáveis, com intuito de dar visibilidade às atividades do galpão e apresentar a escola como mais um ponto de recebimento dos OGRF separados e acondicionados adequadamente, conforme as orientações.

A sequência do Workshop foi a seguinte:

1을 momento: Palestra;

2o momento: Apresentação da dança coreografada, ao som da música: Planeta água, de Guilherme Arantes;

3o momento: Café com entrevistas;

4ำ momento: Entrega da receita impressa em papel reciclado e um sabão ecológico em barra para cada participante.

Vale ressaltar que, como o Workshop fez parte da semana do Meio Ambiente, o evento foi aberto a todos os pais de alunos da E.M. Júlio Benedicto Mendes (comunidade), porém, as ligações foram feitas, apenas, para os pais dos alunos do $4^{\circ}$ ano, na qual a presença foi essencial para a finalização do projeto. Aos demais pais e/ou responsáveis, foi enviado o convite por intermédio dos alunos. 
Durante a palestra, foi explicado que os alunos que participaram da dança foram os que participaram integralmente do projeto, mas que o café, as receitas e o sabão ecológico em barra seriam entregues a todos os participantes do evento (workshop).

Conforme levantamento, $70 \%$ dos pais e/ou responsáveis pelos alunos do $4^{\circ}$ ano compareceram ao Workshop, além de alguns professores da escola e pais e/ou responsáveis por alunos de outras salas. No total, compareceram cerca de 35 pessoas. Dos 14 pais e/ou responsáveis pelos alunos do $4^{\circ}$ ano, 10 pais participaram das entrevistas. Os outros quatro (4), por motivo de transporte, precisaram sair antes das entrevistas.

Os resultados dos questionários e entrevistas serão relatados mais adiante.

\section{Workshop: Meio Ambiente - Apresentação de dança coreografada ao} som da música: Planeta Água, de Guilherme Arantes (consta a letra no apêndice).

Para encenação, foram utilizados retalhos de papel crepom azul nos braços, representando a água, e a figura de um planeta construído a partir de retalhos de papel cartão, além da coreografia (Figura 17).

Figura 17 - Workshop: Apresentação musical

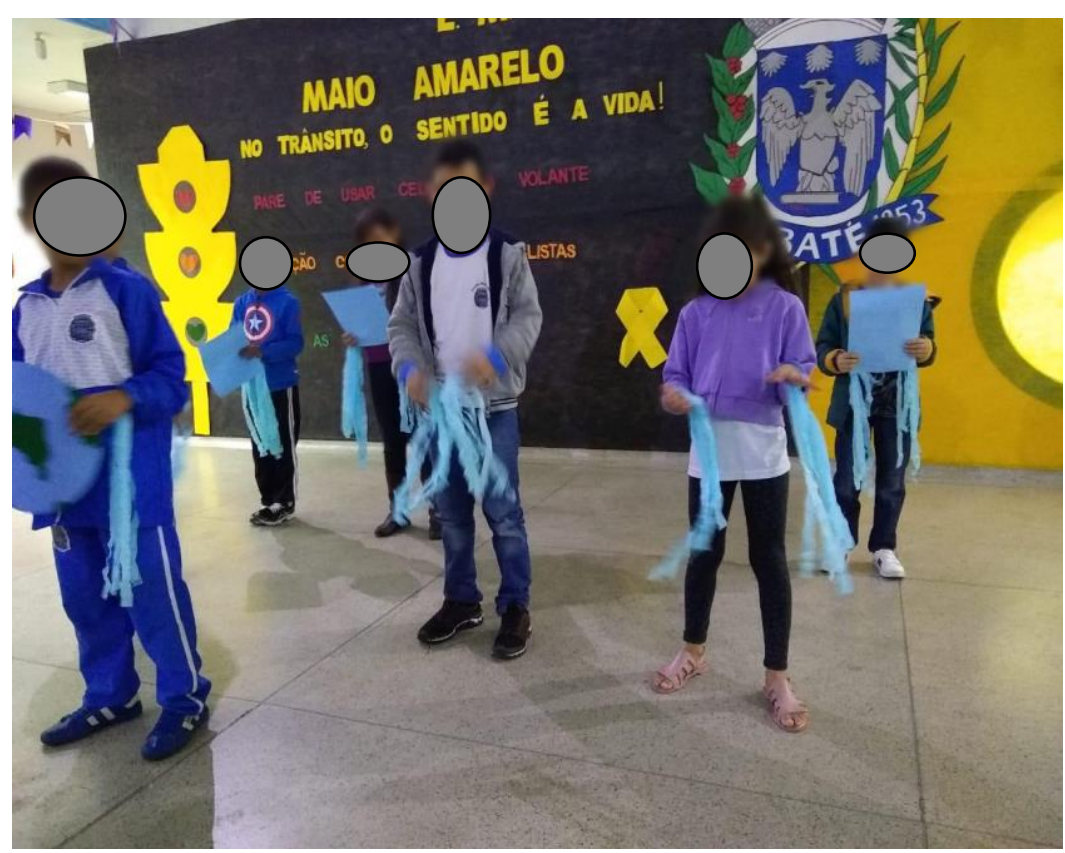

Fonte: Arquivo da pesquisadora (2019). 
Palestra - Tema: Resíduos Sólidos Domésticos: LIXO OU RECURSO? (Figuras 18, 19 e 20)

Tendo como foco os óleos e gorduras residuais fritura - reciclagem e descarte, palestra dissertou sobre:
a) conceito de resíduo e rejeito;
b) impactos ambientais por óleos e gorduras residuais de fritura;
c) panorama do galpão de reciclagem do Município;
d) área de abrangência da coleta seletiva;
e) separação e acondicionamento adequados dos OGRF;
f) alternativas sustentáveis para os OGRF, com ênfase na confecção de sabão ecológico;

g) apresentação da escola como mais um ponto de recebimento de OGRF devidamente separados e acondicionados.

Figura 18 - Palestra - Resíduos Sólidos

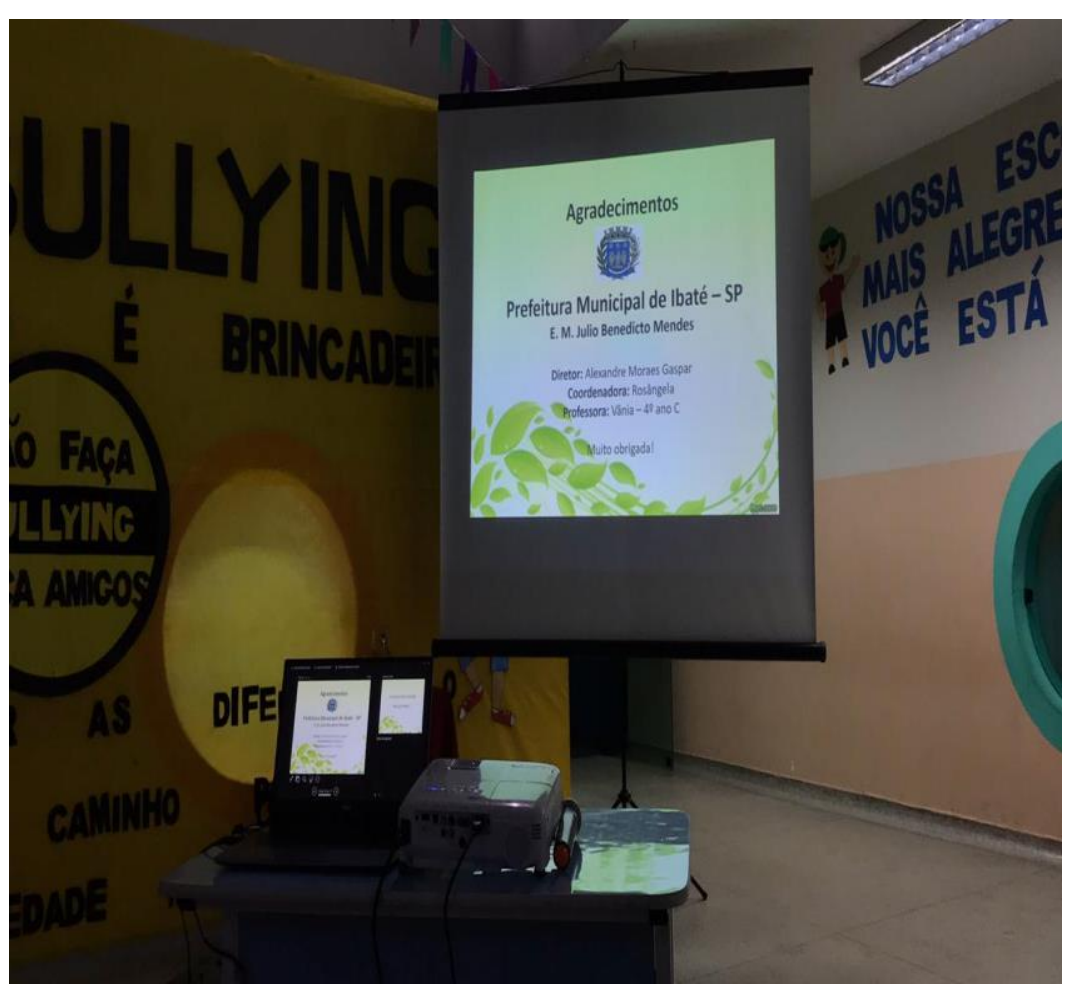

Fonte: Arquivo da pesquisadora (2019). 
Figura 19 - Palestra - Resíduos Sólidos

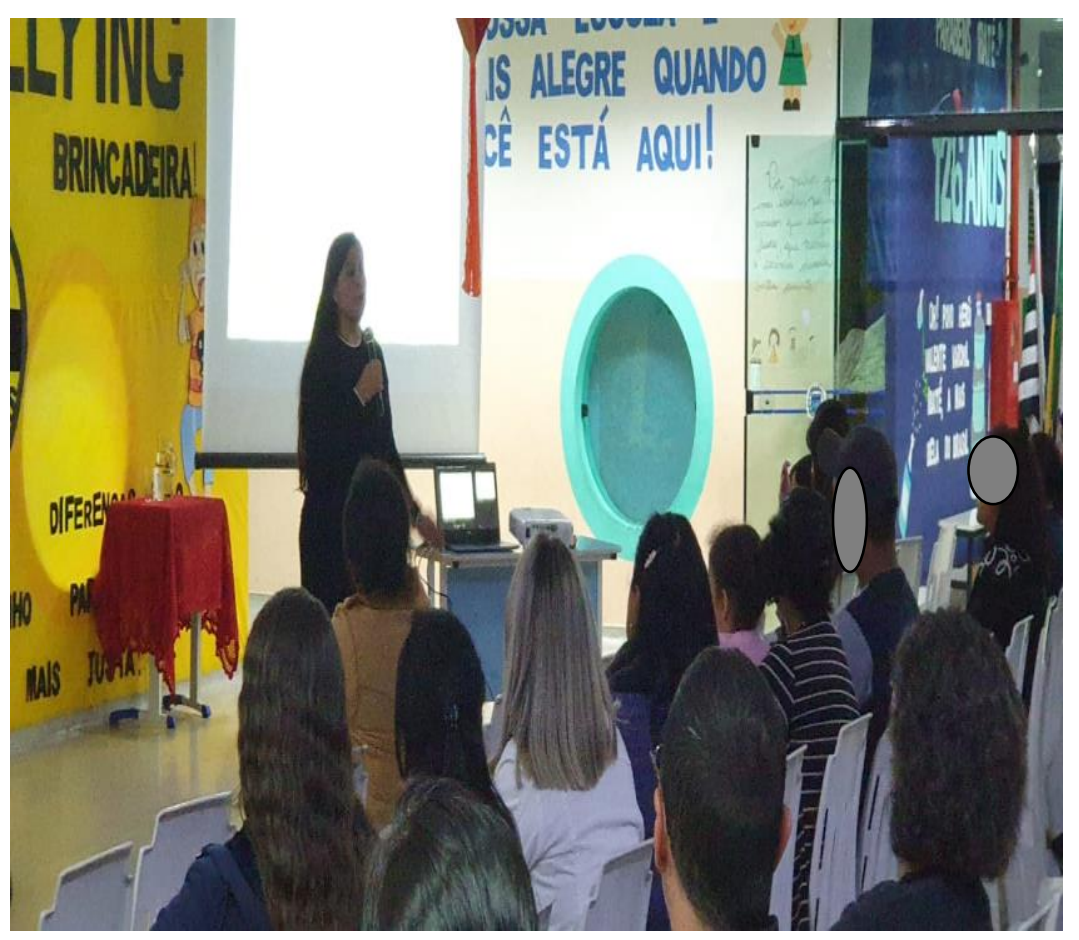

Fonte: Arquivo da pesquisadora (2019).

Figura 20 - Público da Palestra

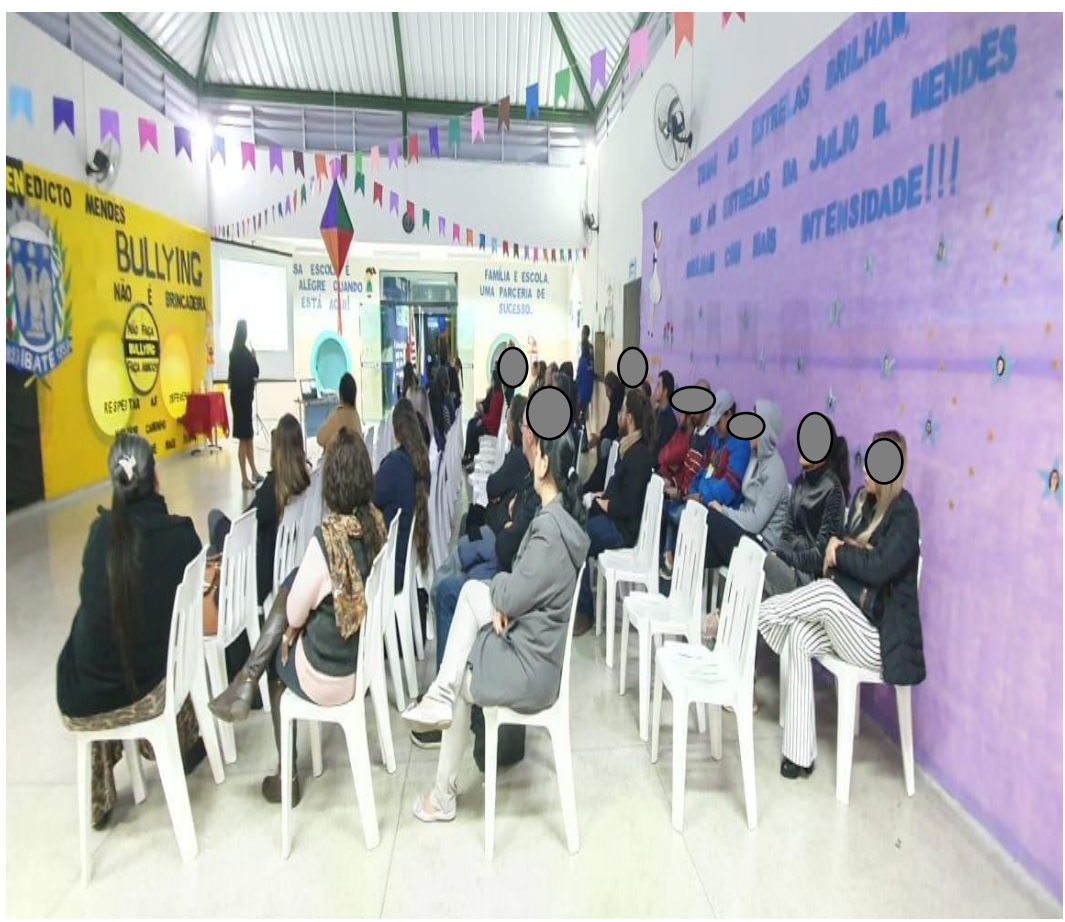

Fonte: Arquivo da pesquisadora (2019). 
Workshop - café com entrevistas

Ao final do workshop, foi oferecido um farto café. Neste momento, a pesquisadora, por meio de uma conversa informal, assim como é característico da técnica de entrevista aberta, entrevistou os 10 pais e/ou responsáveis pelos alunos do $4^{\circ}$ ano, participantes da pesquisa, a fim de analisar o impacto do projeto na vida dessas pessoas em relação à responsabilidade socioambiental, visto que, por meio do primeiro levantamento de dados (aplicação do questionário) foi possível identificar que $57 \%$ dos participantes descartavam os OGRF de maneira inadequada, sendo fundamental a realização do café com entrevistas para averiguar as práticas de manejo dos OGRF. Reitera-se que as perguntas foram pensadas previamente, mas não foi preciso nenhuma formalidade para respondêlas. Abaixo, seguem os questionamentos, respostas e análise das entrevistas.

\section{Perguntas utilizadas durante as entrevistas:}

1 - O que você achou desse projeto voltado aos resíduos sólidos, mais especificamente, os OGRF, para inserção da sustentabilidade na escola? A integração do projeto aos componentes curriculares e integração dos pais e/ou responsáveis, foi positiva?

2 - Antes do projeto, você conhecia os danos causados ao meio ambiente por meio de descarte inadequado desses resíduos?

3 - Refletindo acerca de todo o percurso do projeto: apresentação do projeto em reunião, conhecimentos adquiridos e/ou atualizados junto aos alunos, informações multiplicados pelos alunos no seio familiar e todo o conteúdo da palestra, você o achou relevante para sua vida? E quanto aos hábitos de reciclagem e descarte, alguma coisa mudou?

4 - Você achou importante a escola ser mais um ponto de recebimento de óleos e gorduras residuais de fritura?

5 - Você tem alguma sugestão para acrescentar, algo que poderia ser abordado no decorrer do projeto e não ocorreu? 


\section{RESPOSTAS}

*Importante: para facilitar o entendimento, serão utilizadas as 10 primeiras letras do alfabeto para classificar os 10 participantes das entrevistas:

A - (1) - Achei muito interessante porque na escola só tinha lugares para depositar lata, papel... E para o óleo eu não tinha visto ainda. (2) - Eu não sabia que o óleo causava tanto estrago assim, então resolvi mudar o jeito de descartar o óleo, vou entregar aqui na escola. Meu filho vem pra cá e já traz. (3) - Sim, foram muito importantes, a gente não sabia de tudo isso. (4) - Muito importante. Você falou que pode entregar o óleo no galpão, mas é muito longe de casa. (5) - Não sei, achei que foi bem trabalhado.

B - (1) - Achei legal, precisava disso aqui na escola. (2) - Conhecia em partes, tudo não. (3) - Sim, foi muito legal e meu filho sabe até mais que eu sobre o assunto e agora não me deixa jogar o óleo no terreno ao lado da minha casa. (4) Sim, facilita bastante. (5) - Essas informações poderiam ser passadas todos os anos, porque entram pessoas novas na escola.

C - (1) - Foi muito importante e achei que minha filha ficou feliz por eu participar junto com ela. (2) - Sabia que entupia os canos, mas o resto eu não sabia. (3) - Achei importante e uma época eu fiz sabão com o óleo, mas parei por causa da correria, agora vou voltar a fazer. (4) - Sim. (5) - Não, achei tudo bom.

D - (1) - Foi muito bom, deveria acontecer com mais frequência. (2) - Não conhecia direito. (3) - Sim, é sempre bom aprender. (3) - Sim, eu fiquei sabendo das coisas ruins que o óleo provoca na natureza, mas eu já fazia sabão. (4) Sim. Eu faço sabão, mas vou falar para os meus vizinhos. (5) - Acho que não, foi positivo.

E - (1) - Achei bem interessante o tema, normalmente, só trabalham com papel, metal e plástico. (2) - Não sabia de tudo isso. (3) - Sim, aprendi bastante e agora vou trazer meu óleo usado aqui na escola. (4) - Sim, vou descartar aqui na escola. (5) - Acho que poderia fazer sabão aqui na escola com o óleo que o povo trouxer e usar o sabão pra limpar a escola, iria economizar.

F - (1) Gostei muito do trabalho e a gente participa junto com os filhos, é legal. (2) - Só sabia que não podia jogar no ralo, mas não sabia o motivo. (3) - Sim, eu fiquei sabendo o motivo de não poder jogar no ralo, na terra, e agora sei onde e como descartar. (4) - Sim, fica mais perto de casa. (5) - Acho que foi bom. 
G- (1) - Foi importante poder participar e as crianças já vão aprendendo desde cedo. (2) - Sabia um pouco. (3) - Aprender é sempre bom, ainda mais sobre coisas que estragam o meio ambiente, agora já sabemos como fazer. (4) - Sim, eu não moro tão longe do Galpão, mas aqui é ainda mais fácil porque meu neto traz. (5) - Foi muito bom, mas acho que você poderia falar disso para outras pessoas também, na praça, na Pirâmide (pista de caminhada onde vão muitas pessoas passear com os filhos etc.).

H - (1) - Quando minha filha falou que ia ter esse trabalho aqui na escola, achei muito bom. (2) - Não sabia, estou separando o óleo em garrafas e agora vou entregar aqui na escola. (3) - Sim, se polui o meio ambiente é importante, vou entregar para uma vizinha que faz sabão. (4) - Sim, muito bom para todo mundo. (5) - Acho que não, foi muito bom.

I - (1) - Eu uso bastante óleo e não descartava corretamente, para mim foi muito bom e meu enteado aprendeu também. (2) - Não sabia de tudo. (3) - Me ensinou como descartar o óleo corretamente. (4) - Sim, é fácil de trazer. (5) - Não, acho que foi bom.

J- (1) - Eu achei bem importante aprender sobre o óleo. (2) - Sabia de algumas coisas (3) - Sim, muito importante, vou procurar sempre descartar corretamente ou fazer sabão quando tiver tempo.

As entrevistas buscaram responder a questões fundamentais sobre 0 impacto do projeto para a responsabilidade socioambiental, mudanças de comportamentos e relevância da escola em ser mais um ponto de recebimento dos OGRF devidamente segregados e acondicionados. Por meio das entrevistas, os participantes relataram que, normalmente, as escolas trabalham projetos de EA envolvendo resíduos sólidos, mas o óleo de fritura não costuma ser incluído nesses projetos. Eles mencionaram também que, antes da aplicação do projeto, conheciam pouco ou até mesmo desconheciam os impactos ambientais provocados pelo descarte inadequado dos OGRF, e, por esse motivo, utilizavam práticas insustentáveis. Mesmo as pessoas que responderam que praticam a reciclagem do óleo e fazem sabão ecológico ou que entregam para terceiros que também fazem sabão ecológico, não conheciam, de fato, os impactos provocados por esse tipo de resíduo. 
Vale ressaltar que a escola, enquanto espaço de formação e transformação social, é fundamental para levar aos alunos, familiares e comunidade, temáticas relacionadas ao meio ambiente que sejam relevantes para despertar a responsabilidade socioambiental dos cidadãos.

Por meio da revisão da literatura foi possível confirmar que a integração dos pais e/ou responsáveis pelos alunos favorece a aprendizagem, já que a primeira instância de instrução das crianças é a família. Dessa maneira, a parceria entre família, escola e comunidade promove a aproximação de ambas as partes e multiplica os conhecimentos para além dos muros da escola.

A partir da visita da pesquisadora ao galpão da reciclagem, foi possível levar informações aos envolvidos sobre segregação e descarte dos OGRF, pois a Política Nacional de Resíduos Sólidos (PNRS, 2010) cita sobre a responsabilidade socioambiental e compartilhada em relação a esse tipo de resíduo, mas não dispõe sobre como segregar e/ou descartá-lo adequadamente. De acordo com informações obtidas por meio dos funcionários atuantes do galpão, é possível afirmar que a segregação e acondicionamento dos OGRF podem ser feitos em potes de plásticos ou vidros e garrafas pet, pois esses recipientes não alteram as propriedades do resíduo. Quando os ORF chegam ao galpão, são despejados em um tambor e, posteriormente, vendidos à fábrica de ração animal.

Os recipientes onde são acondicionados os OGRF, após serem desocupados, são encaminhados à triagem e separados conforme suas características e, posteriormente, também são encaminhados para a reciclagem.

Após todo o percurso do projeto, e em conformidade com a gestão da escola, foi possível disponibilizar o ambiente escolar como mais um ponto de recebimento dos OGRF devidamente segregados e acondicionados. Em geral, de acordo aos respondentes das entrevistas, a escola, como ponto de recebimento dos OGRF, facilitou a entrega porque, à medida que os alunos vão à escola, poderão levar consigo os OGRF e os depositar. E, quando a escola já tiver um volume considerável desses resíduos, em torno de 30 ou 40 litros, deverá entrar em contato com o galpão da reciclagem para que eles possam retirá-los.

Para a pesquisadora foi relevante saber se, pela ótica dos participantes, faltou alguma informação ou atividade que eles gostariam que fossem contempladas durante o projeto. Entre as respostas que mais chamaram a atenção da pesquisadora estavam: o projeto foi muito positivo e deveria acontecer mais 
vezes; o trabalho poderia ser desenvolvido na praça ou na Pirâmide para alcançar um maior número de pessoas; poderiam produzir o sabão ecológico na escola a partir dos OGRF entregues, dessa maneira seria possível economizar e utilizar os sabões produzidos para limpeza da escola.

Em relação às mudanças de comportamentos, percebeu-se, que após os envolvidos conhecerem, de fato, os impactos ambientais provocados por meio do descarte inadequado dos OGRF, mudaram, significativamente, seus hábitos. Os que já reciclavam perceberam a importância da reciclagem para o meio ambiente e os que descartavam na pia, na terra ou no ralo, passaram a segregar e acondicionar os resíduos para entregar aos pontos de recebimento. Dessa maneira, os impactos positivos observados no manejo dos OGRF são indicadores do processo de sensibilização e responsabilidade socioambiental.

Assim, percebeu-se que é possível minimizar os impactos ambientais produzidos pelos OGRF a partir de desenvolvimento de projetos na escola incluindo as famílias e demais responsáveis. Porém, é preciso que o trabalho seja realizado de maneira processual, contínua e envolva o maior número de pessoas possível porque mudanças de hábitos só acontecem quando a consciência está sensibilizada. 


\section{CONSTRUÇÃO DO PRODUTO FINAL - CARTILHA EDUCATIVA - Sequência didática para inclusão da sustentabilidade no espaço escolar e comunidade: alternativas sustentáveis para os óleos e gorduras residuais de fritura}

Segundo a CAPES (2019), os cursos de Mestrado Profissional na área de ensino preveem a produção intelectual, ou seja, produtos educacionais que possam ser utilizados por educadores e/ou outros profissionais envolvidos com o ensino formal e não formal. Dessa maneira, e de acordo aos objetivos da presente pesquisa, a cartilha educativa, produto final deste trabalho, foi elaborada a partir da compilação das atividades sistematizadas desenvolvidas de maneira interdisciplinar e transversal aos componentes curriculares da área de Linguagens e Códigos: língua portuguesa e arte; da área de Ciências Humanas: Geografia; e da área da Matemática: componente curricular matemática.

De acordo com a BNCC (2017), no campo das habilidades e competências a serem desenvolvidas por meio de cada componente curricular, utilizou-se a temática ambiental relacionada aos impactos provocados pelos óleos e gorduras residuais de fritura (OGRF) para inserção da sustentabilidade no espaço escolar e comunidade.

Abaixo, segue a organização do produto final:

Figura 21 - Conteúdos constantes da cartilha

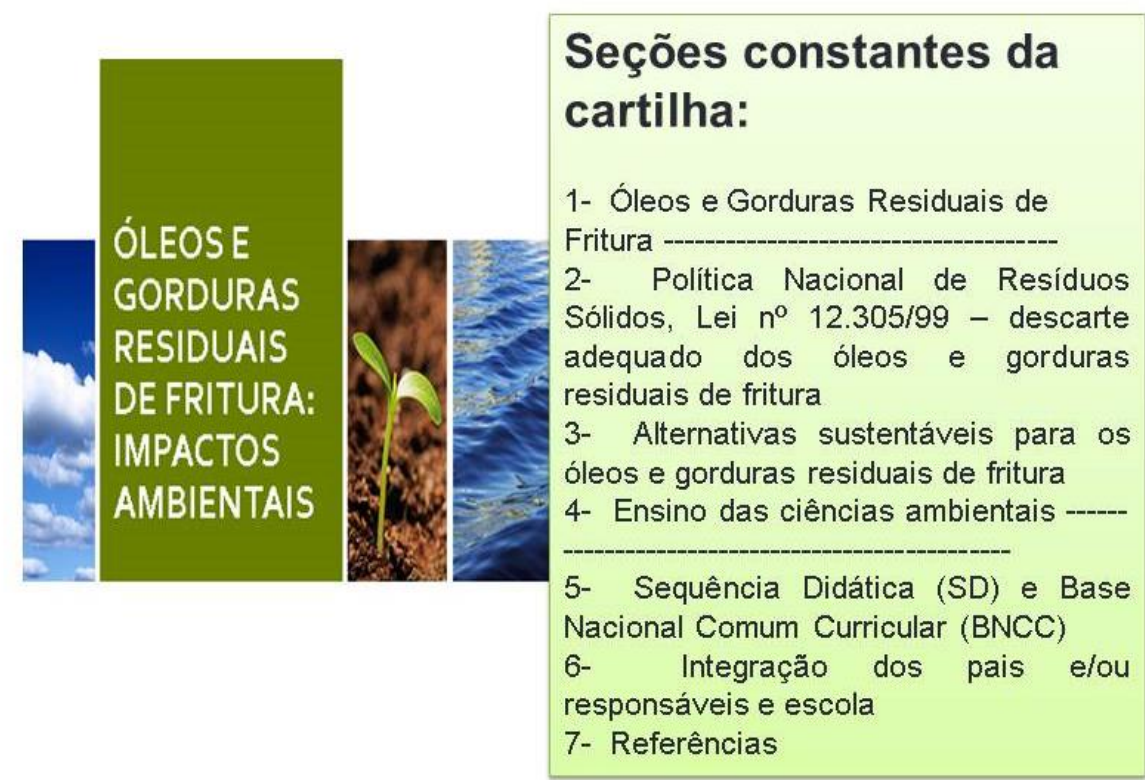

Fonte: Arquivo da pesquisadora (2019). 
A validação do produto educativo foi constituída em várias etapas e por vários atores envolvidos: aos pais e/ou responsáveis foi explanado o assunto durante uma reunião de pais na qual houve entrega de questionário para levantamento de práticas de descarte dos OGRF, utilizadas anteriormente ao projeto, participação em workhop com palestras, e café com entrevistas. Durante as entrevistas, foi possível identificar mudanças de comportamento por meio da sensibilização para a responsabilidade sociambiental a partir da inserção da sustentabilidade na escola através do desenvolvimento do projeto desta pesquisa.

Durante a aplicação das atividades sistematizadas (SD) junto aos alunos, os resultados foram obtidos por meio das habilidades e competências adquiridas junto aos componentes curriculares já mencionados, comprovadas por meio da realização das atividades propostas e detalhadas na seção de resultados e discussões.

Quanto à sequência didática constante da cartilha, é possível afirmar que auxiliará como instrumento para inserção da sustentabilidade no ambiente escolar ou em outros espaços educativos, por profissionais da educação e/ou outros envolvidos com o ensino. Pela repercussão positiva observada pela professora regente do $4^{\circ}$ ano, durante as aulas, as habilidades e competências adquiridas pelos alunos no decorrer do projeto serviram como pré-requisitos para aprofundamento de conteúdos mais avançados, propostos pelos componentes curriculares em consonância à BNCC (2017).

A cartilha educativa estará disponível em formato digital, no banco de dissertações e teses da USP, na área de ciências ambientais. 


\section{CONSIDERAÇÕES FINAIS}

A presente pesquisa buscou responder a três perguntas: Como levar para a sala de aula materiais que sensibilizam os participantes para as questões ambientais, mais especificamente, que despertem a responsabilidade socioambiental para o manejo dos OGRF? Quais os instrumentos utilizar para levantamento dos conhecimentos prévios e processo de sensibilização junto aos pais e/ou responsáveis e comunidade? Os materiais produzidos poderão subsidiar o trabalho de outros profissionais interessados pela temática?

Partindo da primeira pergunta de pesquisa, foi possível concluir que a apresentação da temática ambiental, em específico os OGRF como resíduos potencialmente poluidores dos mananciais, solo e ar, foi fundamental para o diálogo, por meio da roda de conversa, entre a pesquisadora, alunos e professora regente e direcionar as atividades sistematizadas, tendo a compreensão de que é necessário partir da realidade do aluno para que haja sensibilização para as questões de ordem ambiental.

O ensino das ciências ambientais é descrito pela BNCC (2017) nos Temas Contemporâneos Transversais (TCTs) e a orientação proposta é de que eles sejam desenvolvidos de maneira interdisciplinar e transversal, permeando todas os componentes curriculares, visando à formação integral do aluno e preparando-o para o exercício responsável da cidadania. Dessa maneira, infere-se que a inserção da sustentabilidade no ambiente escolar e comunidade por meio da sequência didática, permeando os componentes curriculares de Língua Portuguesa, Arte, Matemática e Geografia, teve impacto positivo para a formação e transformação da consciência ecológica do indíviduo e o despertar da responsabilidade sociambiental dentro da perspectivia crítica de educação. Segundo Zaballa (1998), a SD é utilizada quando se tem um objetivo educacional a ser alcançado, sendo o objetivo da educação básica orientado pela BNCC: a formação integral do aluno para agir e transformar criticamente a própria realidade (BRASIL, 2017). Nesse sentido, o educador Paulo Freire propunha uma educação pautada na realidade do educando "Uma educação para a decisão, para a responsabilidade social e política" (Freire, 1979, p. 88).

A vertente educacional defendida por Paulo Freire encaixa-se nas teorias 
contra-hegemônicas, ou seja, aquelas que entendem a educação sob perspectiva crítica, como forma de libertação e emancipação e que, ao longo da trajetória da educação, foram-se delineando-se de acordo com os objetivos da época, levando em consideração questões políticas e sociais. Nesse sentido, observou-se a importância da elaboração das atividades sistematizadas estarem embasadas em orientações de documentos e teorias de estudiosos que reforçam a necessidade do desenvolvimento global do aluno, bem como para o exercício da cidadania - que só é possível de ser alcançado por meio da vertente educacional crítica, que possibilita ao aluno ser o protagonista em busca do conhecimento.

Esta pesquisa também buscou verificar quais instrumentos utilizar para o levantamento dos conhecimentos prévios acerca das práticas utilizadas para o descarte dos OGRF e processo de sensibilização dos pais e/ou responsáveis, por se tratar de um tema (OGRF), geralmente, manipulado pelos responsáveis.

É importante ressaltar que a gestão escolar acompanhou e contribuiu significamente para a realização desta pesquisa e, conforme informações obtidas durante diálogos informais que aconteciam durante a permanência da pesquisadora no ambiente escolar foi possível saber que os pais e/ou responsáveis iam à escola exporadicamente. Dessa maneira, percebeu-se que a utilização do questionário (enviado aos pais pelos alunos), e a realização de entrevistas, como ferramentas para coleta de dados, foi uma maneira positiva de incluí-los e fomentar a particpação deles, na tentativa de inserir a sustentabilidade para além dos muros da escola.

A estratégia de busca para integração dos pais e/ou reponsáveis (por meio de reunião de pais) também foi positiva, pois, conforme relatado na seção de resultados, houve envolvimento por parte deles e mudanças de atitudes que foram relatadas pelos alunos no momento da roda de conversa e durante o momento do café com entrevistas. Essas mudanças de atitude são indicadores de que o percurso percorrido foi positivo para alcançar o objetivo da pesquisa: sensibilização e transformação da consciência dos envolvidos. Vale ressaltar que as entrevistas aconteceram durante a realização do workshop, confome já detalhado na seção resultados, momento valioso para levar informações sobre o galpão da reciclagem e dinâmica de funcionamento dos aterros. Sabe-se que, enquanto munícipes, ouve-se falar sobre eles, mas a realidade do local é desconhecida, sendo essa uma rica oportunidade de apresentar lugares que fazem parte da vida social. 
A terceira e última pergunta de pesquisa discorre sobre os materiais produzidos, se poderão subsidiar o trabalho de outros profissionais interessados pela temática.

É importante ressaltar que durante todo o percurso de aplicação da SD, em sala de aula, foi fomentada a participação e o envolvimento dos alunos com o propósito de desenvolver a consciência ecológica na perspectiva crítica de educação, tornando o indivíduo conhecedor de seus direitos e deveres e ser capaz de agir com responsabilidade para a cidadania. Dessa maneira, conclui-se que esse material é relevante para os processos formativos de sensibilização de pessoas para as questões ambientais, podendo ser utilizado por educadores e/ou demais interessados pela temática, pois, por meio dele, os alunos conseguiram assimilar os conteúdos propostos nas atividades, ainda que não tivessem o total domínio de certas habilidades, sendo possível trabalhá-las para que eles as adquirissem competências para inserção de conhecimentos mais avançados, além de atingir ao próposito de despertá-los para a responsabilidade sociomabiental. Esse aspecto pôde ser observado em uma das atividades da sequência didática, no componente curricular de Língua Portuguesa, por meio da proposta de escrita da poesia cujo tema foi poluição ambiental, na qual foi possível visualizar que o aluno não dominava completamente os processos da escrita, mas conseguiu captar a mensagem de que somos parte do ambiente e dele devemos cuidar.

Vale ressaltar ainda que a sequência didática, constante do produto final, foi planejada para ser trabalhada com alunos de $4^{\circ}$ ano, mas poderá ser adaptada a outros anos/séries que compoem os anos finais do ensino fundamental I por meio de adequações dos conteúdos dos componentes curriculares de acordo com o ano/série a ser desenvolvido, conservando o tema resíduos sólidos, em específico, os OGRF.

Todo o trabalho que tenha por objetivo a sensibilização de pessoas para transformação da realidade social deve ser processual e contínuo, pois, as mudanças de comportamentos vão acontecendo ao longo do percurso. A escola enquanto espaço de formação e transfomação do indivíduo deve estar engajada em não deixar os projetos que envolvem as questões ambientais descontinuarem, contribuindo para a formação integral do aluno e responsabilidade socioambiental. 


\subsection{SUGESTÕES PARA FUTUROS TRABALHOS}

A inserção da sustentabilidade no contexto da educação básica, por meio do ensino das ciências ambientais, mostrou-se efetiva no processo de sensibilização e formação da consciência ecológica na perspectiva crítica. Nesse sentido, observouse, no decorrer do trabalho, que é possível envolver os alunos, seus responsáveis e/ou comunidade para ampliar o despertar da responsabilidade socioambiental. Por meio das entrevistas pôde-se perceber que as pessoas se interessam e desejam que esse tipo de trabalho seja contínuo no contexto educacional e em demais ambientes que abranjam o maior número de pessoas.

Dessa maneira, como subsídio, está a cartilha educativa com o intuito de auxiliar no processo de inserção da sustentabilidade por educadores e/ou outros interessados pela temática, ressaltando a necessidade de integração das questões ambientais, de ordens local e global, aos demais componentes curriculares constantes da grade da educação básica, contribuindo para a formação integral do aluno. Reitera-se também que o consumo dos óleos e gorduras residuais de fritura, impactos da ingestão dos OGRF na saúde e alimentação saudável são pontos importantes a serem trabalhados, portanto, sugestões para trabalhos futuros. 


\section{REFERÊNCIAS}

ALLINGER, N. L. Química Orgânica. 2.ed. Rio de Janeiro: Editora Guanabara, 1976.

ALVES, R. A magia dos gestos poéticos. 4.ed. São Paulo: Olho d'água, 1995.

JACOBI, R. P. Em foco: a educação ambiental. Revista Educação e Pesquisa, São Paulo, v. 31, n. 2, p. 231-232, ago. 2005 . Disponível em:

http://www.scielo.br/scielo.php?script=sci arttext\&pid=S1517-

97022005000200006\&lng=en\&nrm=iso. Acesso em: 04 mar. 2020.

ABORDAGENS NOTÍCIAS. Nesta quarta-feira tem troca do óleo de cozinha usado por novo em Paraguaçu. 2019.

https://www.google.com/imgres?imgurl=https\%3A\%2F\%2Fwww.abordagemnoticias. com\%2Fuploads\%2Fnoticias\%2F649192611201

9095006.jpg\&imgrefurl=https\%3A\%2F\%2Fwww.abordagemnoticias.com\%2Fnoticia \%2F4843\%2Fnesta-quarta-feira-tem-troca-do- oleo-de-cozinha-usado-por-novo-emparaguacu\&tbnid=YBf0cPRF TOcEM\&vet=10CHEQMyicAWoXChMliKnEk9f 5wIVA AAAABOAAAAAEAI..i\&docid=sJcxWyLVKual $M$

$\& \mathrm{w}=640 \& \mathrm{~h}=454 \& \mathrm{q}=\% \mathrm{C} 3 \%$ B3leo\%20de\%20 cozinha\&ved=0CHEQMyicAWoXChMliK nEk9f 5wIVAAAAABOAAAAAEAl. Acesso em: 04 maio 2020.

ASSOCIAÇÃO BRASILEIRA DE EMPRESAS DE LIMPEZA PÚBLICA E RESÍDUOS ESPECIAIS - ABRELPE. Panorama dos Resíduos Sólidos no Brasil. São Paulo, 2018/2019. Disponível em: http://abrelpe.org.br/download-panorama-2018-2019/. Acesso em: 12 nov. 2019.

BARBIERI, J. C.; SILVA, D. da. Desenvolvimento sustentável e educação ambiental: uma trajetória comum com muitos desafios. RAM, REV. ADM. MACKENZIE, v. 12, n. 3, Edição Especial. SÃO PAULO, maio/jun. 2011, p. 51-82 • ISSN 1678-6971 - Disponível em: http://www.scielo.br/pdf/ram/v12n3/a04v12n3.pdf. Acesso em: 25 nov. 2019.

BRASIL. Consumo sustentável: Manual de educação. Brasília: Consumers International /MMA/ MEC/ IDEC, Brasília-DF, 2005. 160 p. Disponível em: http://portal.mec.gov.br/dmdocuments/publicaca08.pdf. Acesso em: 22 maio 2019.

BRASIL. Constituição Federal da República Federativa do Brasil, texto constitucional promulgado em 5 de outubro de 1988, com as alterações determinadas pelas Emendas Constitucionais de Revisão nos 1 a 6/94, pelas Emendas Constitucionais nos 1/92 a 91/2016 e pelo Decreto Legislativo no 186/2008promulgado em 05 de outubro de 1988. Brasília, DF: Senado Federal, Coordenação de Edições Técnicas, 2016. Disponível em:

https://www2.senado.leg.br/bdst/bitstream/handle/id/518231/CF88 Livro EC91 201 6.pdf. Acesso em: 20 maio /2019. 
BRASIL. Base Nacional Comum Curricular. Educação é Base. Brasília, DF, 2017. Disponível em: http://basenacionalcomum.mec.gov.br/images/BNCC El EF 110518 versaofinal site.pdf. Acesso em: 20 dez. 2019.

BRASIL. Lei $\mathbf{n}^{\circ} \mathbf{9 . 7 9 5}$, de 27 de abril de 1999. Dispõe sobre a educação ambiental, institui a Política Nacional de Educação Ambiental e dá outras providências, Brasília, DF, abril, 1999. Disponível: http://www.planalto.gov.br/ccivil 03/LEIS/I9795.htm. Acesso: 21 maio 2019.

BRASIL. Lei n. 9.394, de 20 de dezembro de 1996. Estabelece as diretrizes e bases da educação nacional. Brasília, DF, 1996. Disponível em:

http://www.planalto.gov.br/ccivil 03/leis/l9394.htm. Acesso em: 20 nov. 2019.

BRASIL. Lei no 11.445, de 05 de janeiro de 2007. Diretrizes Nacionais para o saneamento básico. Brasília: MEC, SEB, DICEI, 2013. Disponível em:

http://www.planalto.gov.br/ccivil 03/ ato2007-2010/2007/lei/l11445.htm. Acesso em: 05 nov. 2019.

BRASIL. Lei $\mathbf{n}^{\circ}$ 12.305, de 2 de agosto de 2010. Institui a Política Nacional de Resíduos Sólidos; altera a Lei n 9.605, de 12 de fevereiro de 1998; e dá outras providências. Brasília, DF, ago. 2010. Disponível em:

http://www.planalto.gov.br/ccivil 03/ ato2007-2010/2010/lei//12305.htm. Acesso em: 21 maio 2019.

BRASIL. Ministério da Educação e do Desporto. Conselho Nacional de Educação. Câmara de Educação Básica. Parecer CEB n. 4/98. Diretrizes Curriculares Nacionais para o Ensino Fundamental. Brasília, DF: MEC/CNE, 1998. Disponível em: http://portal.mec.gov.br/cne/arquivos/pdf/1998/pceb004 98.pdf. Acesso em: 20 nov. 2019.

BRASIL. Ministério da Educação. Diretrizes Curriculares Nacionais da Educação Básica. Brasília, 2013. Disponível em:

http://portal.mec.gov.br/index.php?option=com docman\&view= download\&alias=15548-d-c-n-educacao-basica-nova-pdf\&ltemid=30192. Acesso em: 22 nov. 2019.

BRASIL. Norma Regulamentadora NR 6, de 08 de junho de 1978. Equipamento de Proteção Individual (EPI). Ministério Público do Trabalho: MTb ํ⒊214. Disponível em: https://enit.trabalho.gov.br/portal/images/Arquivos SST/SST NR/NR-06.pdf. Acesso em: 15 dez. 2019.

BRASIL. Parâmetros Curriculares Nacionais, Meio Ambiente. Brasília-DF, 1997. Disponível em: https://cptstatic.s3.amazonaws.com/pdf/cpt/pcn/volume-10-4-temastransversais-meio-ambiente.pdf. Acesso em: 22 nov. 2019.

BRASIL. Plano de Ações Estratégicas para o Enfrentamento de Doenças Crônicas Não Transmissíveis (DCNT) no Brasil, 2011-2022. Ministério da Saúde, 2011, 160 p. Disponível em: http://bvsms.saude.gov.br/bvs/publicacoes/plano acoes enfrent dcnt 2011.pdf. Acesso em: 20 maio 2019. 
BRASIL. Vamos cuidar do Brasil: conceitos e práticas em educação ambiental na escola. MMA / Ministério da Educação/ UNESCO, 2007. 248 p. Disponível em: http://portal.mec.gov.br/dmdocuments/publicacao3.pdf. Acesso em: 22 maio 2019.

CAPES - Coordenação de aperfeiçoamento de pessoal de nível superior. Documento orientador de APCN, Área 46: ensino, 2019. Disponível em: https://capes.gov.br/images/Criterios apcn 2019/ensino.pdf. Acesso em: 01 mar. 2020.

CETESB. Aterros sanitários, aterros controlados e lixões: entenda o destino do lixo no Paraná. Disponível em: https://cetesb.sp.gov.br/biogas/2017/08/01/aterrossanitarios-aterros-controlados-e-lixoes-entenda-o-destino-do-lixo-no-paranal. Acesso em: 10 dez. 2019.

CHASSOT, A. Alfabetização científica: uma possibilidade para a inclusão social. Rev. Bras. Educ. [online]. 2003, n.22, p.89-100. Disponível em: https://doi.org/10.1590/S1413-24782003000100009. Acesso em: 20 fev. 2020.

CIÊNCIAS SOCIAIS APLICADAS EM REVISTA - UNIOESTE/MCR, v.17, n. 32, p. 87-110, 1ํ sem. 2017. Disponível em: https://www.researchgate.net/publication/318886166 Tecnicas de Pesquisa Qualit ativa uma abordagem conceitual. Acesso em: 20 jan. 2020

COMISSÃO MUNDIAL SOBRE MEIO AMBIENTE E DESENVOLVIMENTO (CMMAD). Nosso futuro comum. Rio de Janeiro: Fundação Getúlio Vargas, 1991.

COMPLEXO INDUSTRIAL PORTUÁRIO DE SUAPE. Norma Brasileira ABNT NBR n 10004:2004. Resíduos Sólidos: Classificação. Rio de Janeiro-RJ, 2004.

Disponível em:

http://www.suape.pe.gov.br/images/publicacoes/normas/ABNT NBR n 100042004 .pdf. Acesso em: 24/ fev. 2019.

CONFERÊNCIA DAS NAÇÕES UNIDAS SOBRE MEIO AMBIENTE E DESENVOLVIMENTO (CNUMAD). Agenda 21. São Paulo: Secretaria de Estado do Meio Ambiente, 1992.

CONFERÊNCIA DAS NAÇÕES UNIDAS SOBRE O MEIO AMBIENTE. Declaração De Estocolmo sobre o ambiente humano. Estocolmo, Suécia, 1972. Disponível em: http://www.direitoshumanos.usp.br/index.php/Meio-Ambiente/declaracao-deestocolmo-sobre-o-ambiente-humano.html. Acesso em 15 dez. 2019.

CONFERÊNCIA DAS NAÇÕES UNIDAS SOBRE O MEIO AMBIENTE E DESENVOLVIMENTO. Rio+20. Rio de Janeiro, Brasil, 2012. Disponível em: http://www.rio20.gov.br/sobre a rio mais 20.html. Acesso em: 25 maio 2019.

DELTA, SANEAMENTO AMBIENTAL. Os óleos vegetais são grandes causadores de danos ao meio ambiente quando descartados de maneira incorreta. Mas, o que são óleos vegetais? Disponível em:

http://www.deltasaneamento.com.br/noticia/56/oleo-de-cozinha-e-o-tratamento-deesgotos\#.XIv6ISFKjIV. Acesso em: 01 dez. 2019. 
DIAS, G. F. Educação Ambiental princípios e práticas. 8.ed. Gaia, São Paulo, 2003. 552 p.

ECOLEO. Reciclagem do óleo. Disponível em: http://ecoleo.org.br/projetos/6766-2/. Acesso em: 05 dez. 2019.

FREIRE, P. Conscientização: teoria e prática da libertação - uma introdução ao pensamento de Paulo Freire. 4.ed. São Paulo: Moraes, 1980. 102 p.

FREIRE, P. Educação e mudança. 6.ed. Rio de Janeiro: Paz e Terra, 1983.

FREIRE, P. Não há educação neutra. O Jornal. Lisboa-Portugal, 2 maio 1977. Disponível em: http://www.acervo.paulofreire.org:8080/jspui/handle/7891/1283. Acesso em: 05 dez. 2019.

GIL, A. C. Métodos e técnicas de pesquisa social. 6.ed. São Paulo : Atlas, 2008.

INSTITUTO NACIONAL DE ESTUDOS E PESQUISAS EDUCACIONAIS ANÍSIO TEIXEIRA. PISA: Programa Internacional de Avaliação de Estudantes. Brasil, 2019. Disponível em: http://portal.inep.gov.br/pisa. Acesso em: 05 dez. 2019.

JACOBI, P. R. Educação ambiental: o desafio da construção de um pensamento crítico, complexo e reflexivo. Educação e Pesquisa, São Paulo, v. 31, n. 2, p. 233250, maio/ago. 2005. Disponível em:

http://www.scielo.br/scielo.php?script=sci arttext\&pid=S1517-97022005000200007. Acesso em: 12 abr. 2019.

JACOBI, P. R. Educação Ambiental, Cidadania e Sustentabilidade. Caderno de pesquisa, n.118, março 2003. Disponível em:

http://www.scielo.br/pdf/cp/n118/16834.pdf. Acesso em: 20 maio 2019.

JACQUARD, A. A explosão demográfica. Tradução de Paulo Herculano Marques Gouveis. São Paulo: Ática, 1998.

LAGO, S. M. S.; ROCHA JR., W. F. Logística reversa, legislação e sustentabilidade: o óleo de fritura residual como matéria-prima para produção de biodiesel. Gestão e Sociedade, v. 10, n. 27, p. 1437-1458, 2016. Disponível em:

http://www.spell.org.br/documentos/ver/42598/logistica-reversa--legislacao-esustentabilidade--o-oleo-de-fritura-residual-como-materia-prima-para-producao-debiodiesel. Acesso em: 15 dez. 2019.

LIMA, J. R; GONÇALVES, L. A. G. O processo de fritura: alterações observadas em óleos e gorduras. Boletim SBCTA, São Paulo, v. 29, n.2, p. 179-185, 1995.

LIMA, G. F. C. Educação ambiental crítica: do socioambientalismo às sociedades sustentáveis. Revista Educação e Pesquisa. São Paulo, v.35, n.1, p. 145-163, jan./abr. 2009. Disponível em: http://www.scielo.

br/pdf/ep/v35n1/a10v35n1.pdf. Acesso em: 18 dez. 2019. 
LIMA, N. M. O. et al. Produção e caracterização de sabão ecológico - uma alternativa para o desenvolvimento sustentável do semiárido paraibano. Revista Saúde e Ciência On line, v. 3, n. 3p. 26-36, set./dez, 2014. Disponível em: http://www.ufcg.edu.br/revistasaudeeciencia/index.php/RSCUFCG/article/viewFile/171/108. Acesso em: 10 dez. 2019.

LOUREIRO, Carlos Frederico Bernardo. Educação ambiental e movimentos sociais na construção da cidadania ecológica e planetária. In: LOUREIRO, Carlos Frederico Bernardo; LAYRARGUES, Philippe Pomier; CASTRO, Ronaldo Souza de (Orgs.). Educação Ambiental: repensando o espaço da cidadania. 2.ed. São Paulo: Cortez, 2002.

LOUREIRO, C.F.B. Trajetórias e fundamentos da educação ambiental. 3.ed.São Paulo: Cortez, 2009.

LÜDKE, M.; ANDRÉ, M. Pesquisa em educação: abordagens qualitativas. São Paulo: EPU, 1986.

MARCONI. M.A.; LAKATOS, E. M. Técnicas de pesquisa. São Paulo: ed. Atlas, 1999.

MARCONI, M. A., LAKATOS, E. M. Metodologia Científica. 5.ed. 2.reimpr. São Paulo: Atlas, 2008.

MARSIGLIA, A. C. G. Elementos históricos acerca da didática: do ratio studiorum à didática pós-moderna. Revista Teoria e Prática da Educação, v.20, n.2, p. 03-18, maio/ago. 2017. Disponível em:

http://periodicos.uem.br/ojs/index.php/TeorPratEduc/article/view/45072. Acesso em: 15 dez. 2019.

MILLER JR,T.G. Ciência Ambiental. 11.ed. São Paulo: Thonsom Learning, 2007.

MINAYO, M. C.de S. O desafio do conhecimento científico: pesquisa qualitativa em saúde. 2.ed. São Paulo/Rio de Janeiro: Hucitec-Abrasco, 1993.

NAÇÕES UNIDAS BRASIL. A ONU e o meio ambiente. Brasil. Disponível em: https://nacoesunidas.org/acao/meio-ambiente/. Acesso em: 15 dez. 2019.

PHILIPPI Jr, A. (Org). Política e gestão Ambiental: Conceitos e instrumentos. In: educação ambiental e sustentabilidade. São Paulo: USP, 2004.

PONT, B. Escola deve dar a pais ideia clara sobre o que se espera deles. São Paulo, 2012. Disponível em: https://oglobo.globo.com/sociedade/educacao/beatrizpont-escola-deve-dar-pais-ideia-clara-sobre-que-se-espera-deles-670018. Acesso em: 22 maio 2019.

RAMALHO, H. F.; SUAREZ, P. A. Z. A. Química dos Óleos e Gorduras e seus Processos de Extração e Refino. Revista Virtual de Química, v.5, n.1, p. 2-15, 2013. Disponível em: http://rvq-sub.sbq.org.br/index.php/rvq/article/view/360/279. Acesso em: 12 dez. 2019. 
RIBEIRO, E. A. A perspectiva da entrevista na investigação qualitativa. Evidência: olhares e pesquisa em saberes educacionais, Araxá-Minas Gerais, n. 04, p.129-148, maio 2008. Disponível em: https://www.uniaraxa.edu.brojs/index.php/evidencia/ article/viewFile/328/31. Acesso em: 21 nov. 2019.

ROVIRIEGO, L. F. V. Proposta de uma metodologia para a avaliação de sistemas de coleta seletiva de resíduos sólidos domiciliares. 2005. $192 \mathrm{f}$. Dissertação de mestrado (Pós Graduação em Ciências da Engenharia Ambiental), Escola Engenharia de São Carlos. São Carlos, 2005.

ROSENHAIM, R. Avaliação das Propriedades Fluído-dinâmicas e Estudo Cinético por Calorimetria Exploratória Diferencial Pressurizada (PDSC) de Biodiesel Etílico Derivado de Óleo de Fritura Usado. 2009. 127 f. Tese (Doutorado em Química) Universidade Federal da Paraíba. João Pessoa, 2009.

SANTOS, J. A.; TOSCHI. M. S. Vertentes da Educação Ambiental: da conservacionista à crítica. Journal of Social, Technological and Environmental Science, v.4, n.2, p. 241-250, jul./dez. 2015, Ed. Especial. Disponível em: http://periodicos.unievangelica.edu.br/index.php/fronteiras/article/download/1350/123 1/. Acesso em: 12 out. 2019.

SÃO PAULO (Estado). Coordenadoria e Educação Ambiental. Educação ambiental e desenvolvimento: documentos oficiais/ Secretaria do Meio Ambiente, Coordenadoria de Educação Ambiental. São Paulo, 1994. Disponível em: https://www.infraestruturameioambiente.sp.gov.br/cea/1994/08/educacao-ambientale-desenvolvimento-documentos-oficiais/. Acesso em: 20 fev. 2019.

SAUVÉ, L. Uma cartografia das correntes de educação ambiental. In: SATO, M.; CARVALHO, I. Educação Ambiental: pesquisa e desafios. Porto Alegre: Artmed, 2005.

SCARPA, D. L. O papel da argumentação no ensino de ciências: lições de um workshop. Ensaio Pesquisa em Educação em Ciências (Belo Horizonte). Belo Horizonte, v. 17, n. spe, p. 15-30, nov. 2015. Disponível em http://www.scielo.br/scielo.php?script=sci arttext\&pid=S1983-

21172015000400015\&lng=pt\&nrm=iso. Acesso em: 27 fev. 2020.

SILVA, E.; GOMES, L. S.; SANTANA, V. H. Escola e comunidade: uma relação necessária. Disponível em: https://portal.fslf.edu.br/wpcontent/uploads/2016/12/tcc10.pdf. Acesso em: 15 dez. 2019.

SOUSA, M. M. de; SARMENTO, T. Escola - família - comunidade: uma relação para o sucesso educativo. Gestão e Desenvolvimento. ISSN 0872-556X, n. 17-18, p. 141-156, 2009-2010. Disponível em: https://repositorio.ucp.pt/ handle/10400.14/9117. Acesso em: 01 dez. 2019.

SOUZA, M. Um plano para salvar o planeta. Disponível em: https://www.youtube.com/watch?v=dCOOWSbe6lg\&feature=youtu.be. Acesso em: 10 dez. 2019. 
TERRA, PLANETA ÁGUA. Intérprete: Guilherme Arantes. Compositor: Guilherme Arantes. In: Intimidade. São Paulo: RCA Victor, 2007. 1 CD, faixa 1 (5'53").

THIOLLENT, M. Metodologia da pesquisa-ação. São Paulo: Cortez, 1985.

TRINDADE, N. A. D. Consciência Ambiental: coleta seletiva e reciclagem no ambiente escolar. Enciclopédia Biosfera, Centro Científico Conhecer, Goiânia, v.7, n. 12, p. 1-15, 2011. Disponível em:

http://www.conhecer.org.br/enciclop/2011a/humanas/consciencia\%20ambiental.pdf. Acesso em: 03/08/2019.

UNESCO. Seminário Internacional de Educação Ambiental. Programa Internacional de Educação Ambiental. Carta de Belgrado. Belgrado, Yoguslávia, 1322 de outubro de 1875. Disponível em: https://www.sib.gob.ar/portal/wpcontent/uploads/2019/02/Seminario-Internacional-de-Educaci\%C3\%B3n-AmbientalCarta-de-Belgrado-1975.pdf. Acesso em: 12 ago. 2019.

UNESCO. PROGRAMA DAS NAÇÕES UNIDAS PARA O MEIO AMBIENTE (PNUMA). Declaração de Tbilisi. 1977. Disponível em:

http://www.mma.gov.br/port/sdi/ea/deds/pdfs/decltbilisi.pdf. Acesso em: 20 mar. 2016.

UNITED NATIONS. World Population Prospects 2019. Key Finds and Advance Tables. New York, 2019. Disponível em:

https://population.un.org/wpp/Download/Standard/Population/. Acesso em: 31 out. 2019.

WORLDWATCH, I. Estado do Mundo. Relatório do Worldwatch Institute sobre o Avanço Rumo a uma Sociedade Sustentável. Salvador, BA: 1.ed., 2010.

ZABALA, A. A prática educativa: como ensinar. Porto Alegre: ARTMED, 1998.

ZUCATTO, L. C.; WELLE, I.; SILVA, T. N. da. Cadeia reversa do óleo de cozinha: coordenação, estrutura e aspectos relacionais. RAE-Revista de Administração de Empresas, v. 53, n. 5, p.539-550, set./outubro, 2013. Disponível em: http://www.scielo.br/scielo.php?pid=S003475902013000500003\&script=sci abstract\&tIng=pt. Acesso em: 12 dez. 2019. 


\title{
REFERÊNCIAS DAS IMAGENS DA CARTILHA
}

\author{
ABORDAGENS NOTÍCIAS. Nesta quarta-feira tem troca do óleo de cozinha \\ usado por novo em Paraguaçu. 2019.
}

https://www.google.com/imgres?imgurl=https\%3A\%2F\%2Fwww.abordagemnoticias. com\%2Fuploads\%2Fnoticias\%2F649192611201

9095006.jpg\&imgrefurl=https\%3A\%2F\%2Fwww.abordagemnoticias.com\%2Fnoticia \%2F4843\%2Fnesta-quarta-feira-tem-troca-do- oleo-de-cozinha-usado-por-novo-emparaguacu\&tbnid=YBf0cPRF TOcEM\&vet=10CHEQMyicAWoXChMliKnEk9f 5wIV AAAAABOAAAAAEAI..i\&docid=sJcxWyLVKual $M$

$\& w=640 \& h=454 \& q=\% C 3 \% B 3 l e 0 \% 20$ de\%20cozinha\&ved=0CHEQMyicAWoXChMli KnEk9f 5wIVAAAAABOAAAAAEAl. Acesso em: 04 maio 2020.

BIORIB. Por que a reciclagem do óleo de cozinha é importante? Disponível em: https://biorib.com.br/site/por-que-a-reciclagem-do-oleo-de-cozinha-eimportante/. Acesso em: 02 maio 2020.

CATRAN BLOG. Aprenda a fazer sabão com óleo de cozinha usado. 2017. Disponível em:

https://catranblog.com/2016/10/07/aprenda-a-fazer-sabao-com-oleo-de-cozinhausado/. Acesso em: 03 maio 2020.

CRIANÇA EM QUESTÃO. Família, criança e escola: Um trio afinado a favor da inclusão. Disponível em:

http://www.criancaemquestao.com.br/2016/05/familia-crianca-e-escola-um-trio.html. Acesso em: 10 ago. 2020.

FREEPIK. Disponível em: ttps://br.freepik.com/fotos-gratis/crianca-escrevendoletras-no-bloco-de-notas 1343967.htm. Acesso em:

10 ago. 2020.

LAR PLÁSTICOS. Preservar o meio ambiente: responsabilidade de todos! 2020. Disponível em: https://www.larplasticos.com.br/ultimas-noticias/preservaro-meio-ambiente-responsabilidade-de-todos. Acesso em: 10 ago. 2020.

PORTO SEGURO AUTO. Programa de reciclagem de óleo de cozinha. 2016. (02'15"). Disponível em: https://www.youtube.com/watch?v=M0Aspk5FrLI. Acesso em: 04/05/2020.

SABESP. Óleo e água não se misturam: a solução é reciclar. Disponível em: http://site.sabesp.com.br/site/interna/Default.aspx?secaold=82. Acesso em: 02 maio 2020. 
APÊNDICE A - CARTILHA EDUCATIVA

SEQUÊNCIA DIDÁTICA PARA INCLUSÃO DA SUSTENTABILIDADE NO ESPAÇO ESCOLAR: ALTERNATIVAS SUSTENTÁVEIS PARA ÓLEOS E GORDURAS RESIDUAIS DE FRITURA 


\section{SEQUÊNCIA DIDÁTICA PARA INCLUSÃO DA SUSTENTABILIDADE NO ESPAÇO ESCOLAR:}

\section{Alternativas sustentáveis}

para os óleos e gorduras residuais de fritura
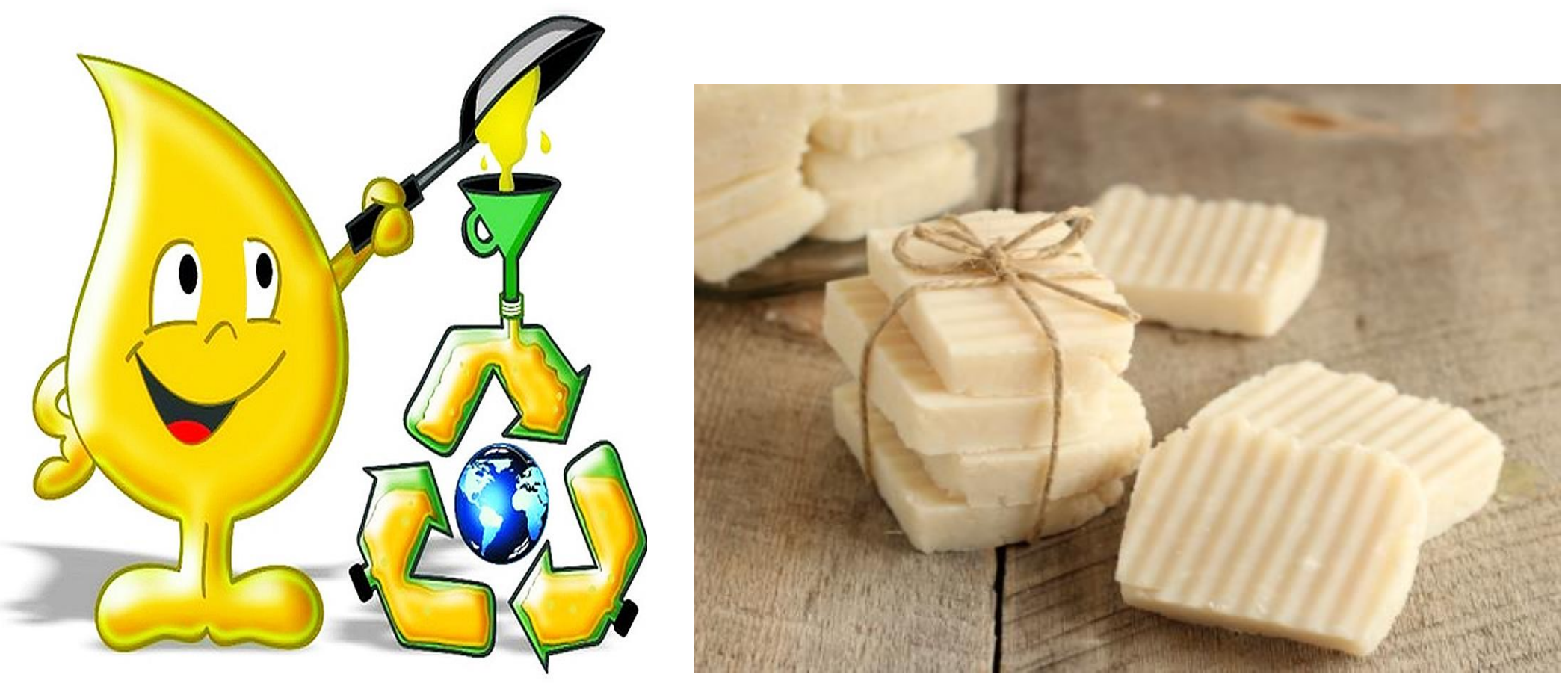

Carla Cristina Castanheiro dos Santos 


\section{UNIVERSIDADE DE SÃO PAULO ESCOLA DE ENGENHARIA DE SÃO CARLOS PROFCIAMB Programa de Pós-Graduação em Rede Nacional para

Carla Cristina Castanheiro dos Santos

Produto Educacional

São Carlos - SP

2020 


\section{Carla Cristina Castanheiro dos Santos}

\section{SEQUÊNCIA DIDÁTICA PARA INCLUSÃO DA SUSTENTABILIDADE NO ESPAÇO ESCOLAR:}

\section{Alternativas sustentáveis para os óleos e gorduras}

residuais de fritura

Produto Educacional apresentado ao

Programa de Pós-Graduação em Rede

Nacional para Ensino das Ciências

Ambientais - PROFCIAMB, como requisito

parcial para obtenção do título de Mestre.

Orientador: Prof. Dr. Tadeu Fabrício Malheiros

São Carlos - SP 2020 


\section{Autoria e diagramação: Carla Cristina Castanheiro dos Santos}

Orientação: Prof. Dr. Tadeu Fabrício Malheiros

\section{Licença Creative Commons}

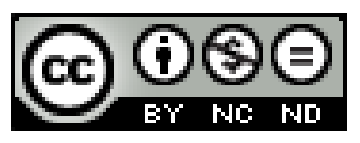

O trabalho Inclusão da sustentabilidade no espaço escolar e comunidade de Carla Cristina Castanheiro dos Santos e Tadeu Fabrício Malheiros está licenciado com uma Licença Creative Commons - Atribuição 4.0 Internacional. 


\section{AGRADECIMENTOS}

O presente trabalho foi realizado com apoio da Coordenação de Aperfeiçoamento de Pessoal de Nível Superior (CAPES) e da Agência Nacional de Águas e Saneamento Básico (ANA).

Ao Prof. Dr. Tadeu Fabrício Malheiros.

À gestão escolar, professores e alunos da Escola Municipal de Ensino Fundamental I Julio Benedicto Mendes do Município de lbaté - SP.

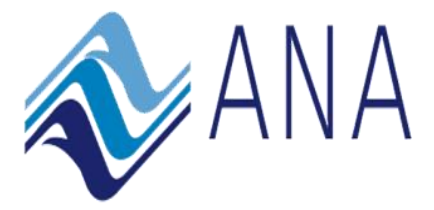

AGÊNCIANACIONALDEÁGUAS
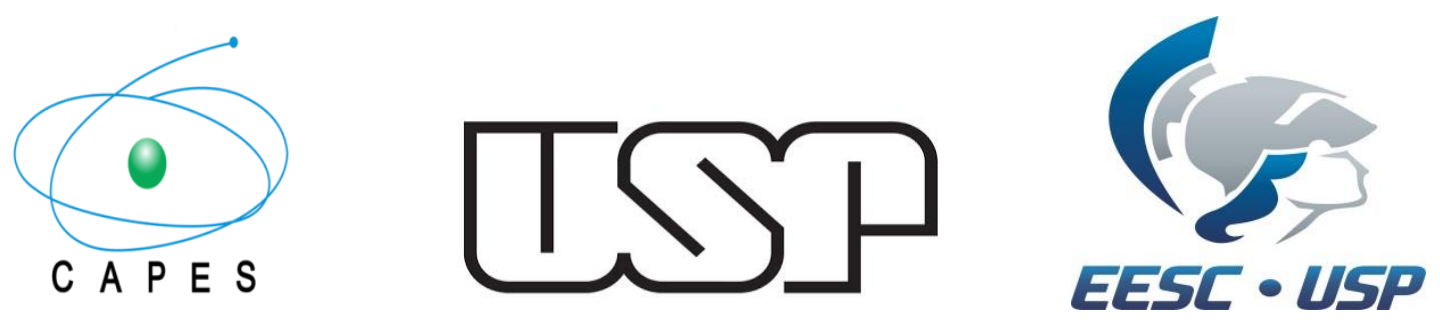
Você sabia que, atualmente, os óleos e gorduras residuais de fritura (OGRF) tornaram-se um dos maiores problemas de ordem ambiental? Então, quando são descartados de maneira inadequada atingem os mananciais, o solo e o ar, impactando-os gravemente. Porém, esses resíduos podem ser reutilizados e reciclados, minimizando os impactos no meio ambiente!

Esta cartilha educativa foi desenvolvida a partir de uma pesquisa de Mestrado realizada junto ao Programa de Pós Graduação em Rede Nacional para Ensino das Ciências Ambientais (PROFCIAMB - USP São Carlos) e direciona-se a professores, alunos dos anos finais do ensino fundamental I e demais interessados pela temática. Propusemos uma sequência de atividades estruturadas (sequência didática - SD), com a finalidade de apresentar os impactos ambientais causados pelo descarte inadequado dos OGRF, formas de descarte e alternativas sustentáveis. A SD foi estruturada sob a luz da interdisciplinaridade e transversalidade, conforme orientações da Base Nacional Comum Curricular (BNCC, 2017), integrando os componentes curriculares de Língua Portuguesa, Arte, Geografia e Matemática.

Ficou interessada (o) em contribuir para a responsabilidade socioambiental das pessoas e construir um mundo melhor? Embarque conosco!

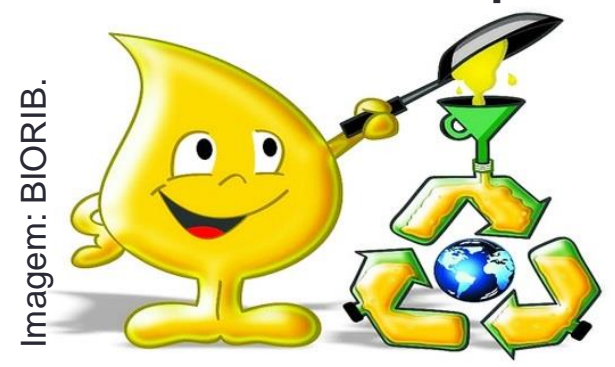


Já iremos adentrar ao conteúdo desta cartilha, mas antes é necessário apresentá-la ao público a que se destina...

\begin{tabular}{|l|}
\hline APRESENTAÇÃO \\
Esta cartilha está estruturada de acordo a \\
BNCC (2017). O conteúdo constante faz \\
parte dos Temas Contemporâneos \\
Transversais (TCTs) e está alinhado aos \\
currículos das disciplinas dos $4^{\circ}$ e $5^{\circ}$ \\
anos do ensino fundamental I.
\end{tabular}

\section{UTILIZAÇÃO}

Os conteúdos foram organizados numa sequência didática sistematizada junto aos componentes curriculares de Língua Portuguesa, Arte, Geografia e Matemática. Portanto, deverá ser utilizada conforme orientações especificadas nas páginas onde estão descritos cada componente curricular.

\section{OBJETIVOS}

Este material foi elaborado para o ensino das ciências ambientais com o objetivo de formar e transformar a consciência ecológica dos educandos e sensibilizá-los para a responsabilidade socioambiental.

\section{PÚBLICO-ALVO}

Professores e alunos dos anos finais do ensino fundamental I (modalidade de ensino da educação básica). 0 material também poderá ser utilizado por outros profissionais envolvidos no ensino e que tenham interesse pela temática. 


\section{SUMÁRIO}

1 - Óleos e Gorduras Residuais de Fritura

2 - Política Nacional de Resíduos Sólidos, Lei oㅜ 12.305/99 - descarte adequado dos óleos e gorduras residuais de fritura.

3 - Alternativas sustentáveis para os óleos e gorduras residuais de fritura.

4 - Ensino das ciências ambientais.

5 - Sequência Didática (SD) e Base Nacional Comum Curricular (BNCC)

6 - Integração dos pais e/ou responsáveis e escola

Referências.

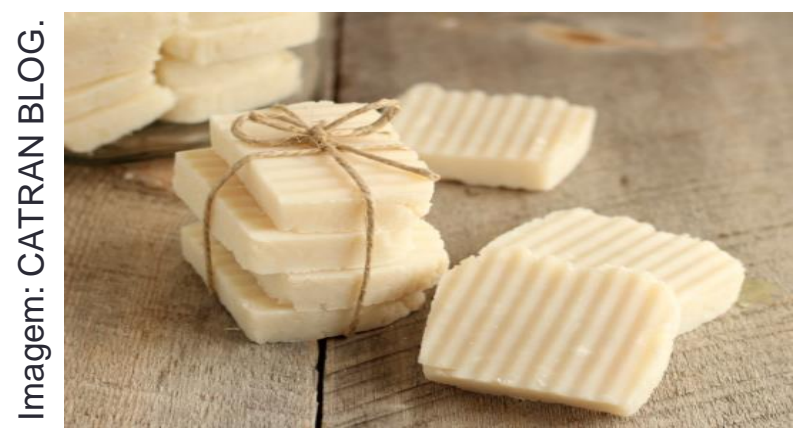


ÓLEOS E

GORDURAS

RESIDUAIS

DE FRITURA:

IMPACTOS

AMBIENTAIS
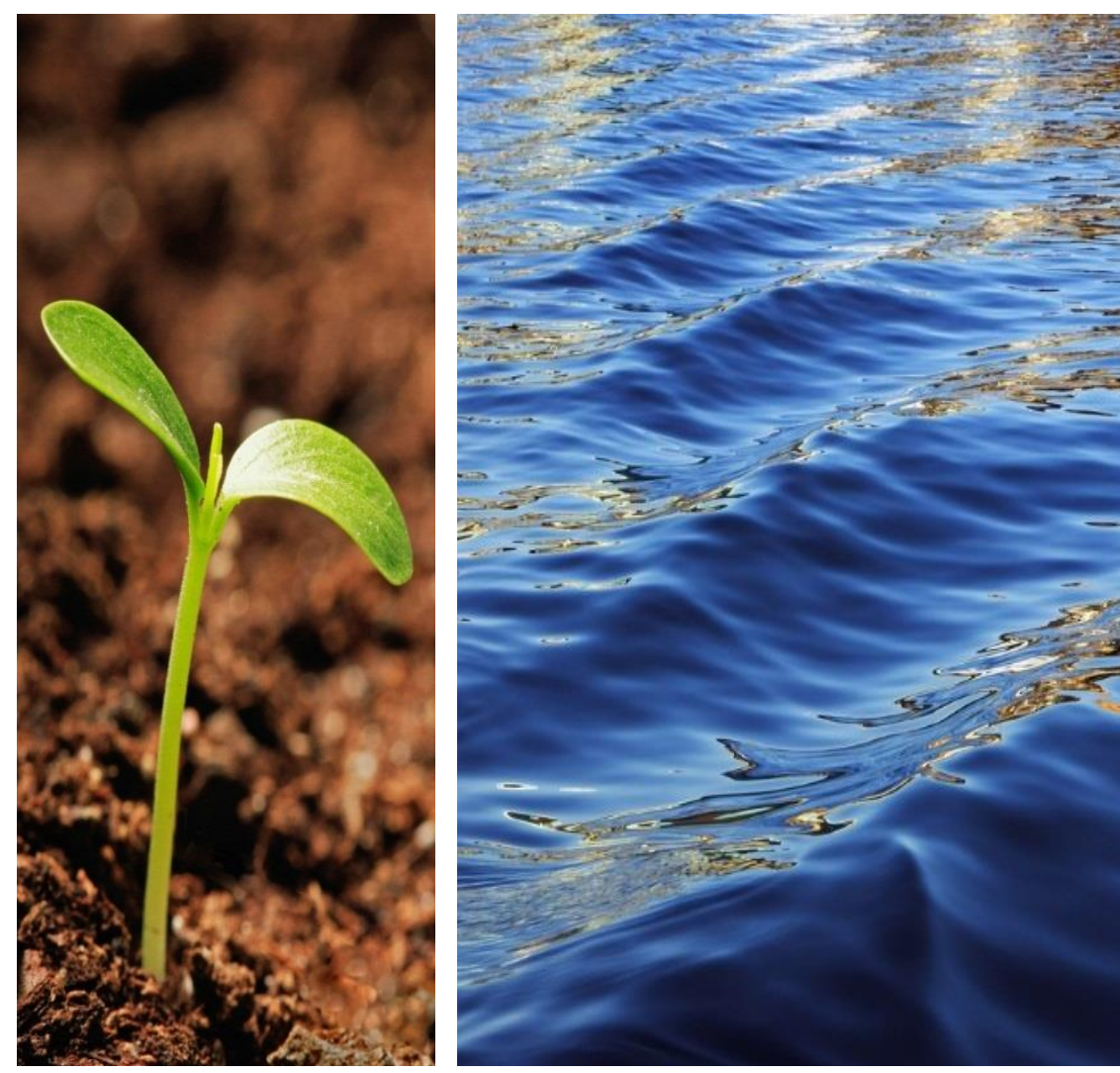
Você sabia que os óleos ou gorduras, após serem utilizados na preparação do seu alimento, tornam-se resíduos de alto potencial poluidor?

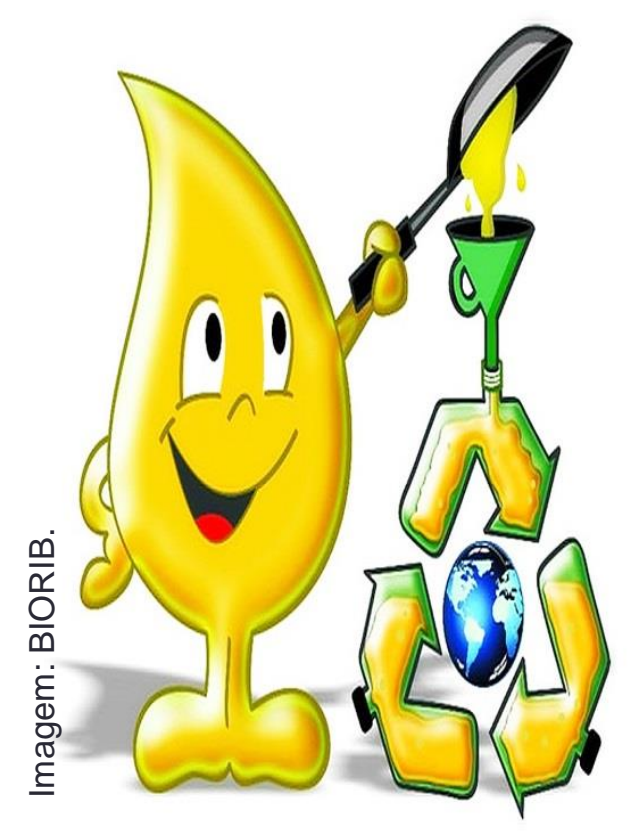

Então, se esses resíduos
forem descartados de forma
inadequada, irão poluir as
águas, o solo e o ar.

A partir de agora, para facilitar, iremos tratar os óleos e gorduras residuais de fritura por: OGRF 
Quando os OGRF chegam aos cursos d'água, impedem a transferência de oxigênio e provocam a morte dos peixes.

Em contato com o solo, os OGRF formam uma camada impermeável tornando a terra improdutiva, além de não permitir a absorção da água e facilitar as enchentes.

Ainda no solo, quando o óleo se mistura à água, forma-se um líquido de odor desagradável que emite um gás poluente (metano), colaborando para o aquecimento global.

Você viu quantos problemas os OGRF causam ao meio ambiente se forem descartados de maneira inadequada?!

Agora que você já sabe sobre os impactos ambientais provocados pelos OGRF, vamos aprender a descartá-los adequadamente. 


\section{POLÍTICA NACIONAL DE RESÍDUOS SÓLIDOS (PNRS), \\ LEI № 12.305/99 - Descarte adequado de óleos e gorduras residuais de fritura}

I - Você sabia que, enquanto cidadãos, somos sujeitos de direitos e deveres?

II - Então, para que possamos ter nossos direitos garantidos, existem as Leis que dispõem sobre nossos deveres...

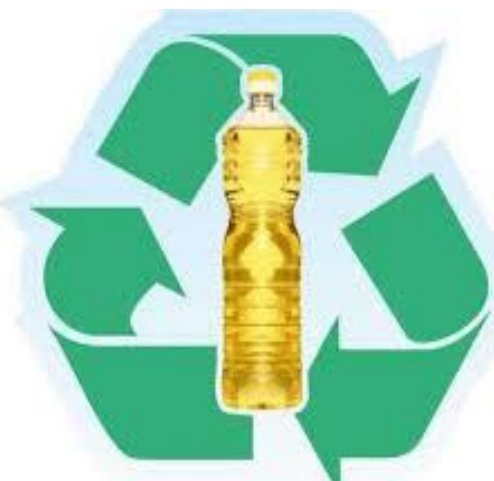

V - A Seção II, Art. 42, ainda dispõe sobre a estruturação da coleta seletiva e, sempre que for estabelecido o sistema de coleta pelo poder público, o consumidor deverá acondicionar adequadamente e disponibilizar os resíduos reutilizáveis e recicláveis para a coleta.

Imagem: ABORDAGENS NOTÍCIAS.

III - Para regulamentar a disposição dos resíduos sólidos, assim como os óleos e gorduras residuais de fritura, temos a Política Nacional dos Resíduos Sólidos - Lei nº 12.305/99.
IV - A Seção II da referida Lei, que institui a Responsabilidade compartilhada, dispõe sobre a logística reversa para os resíduos perigosos. Contudo, os OGRF não estão enquadrados nesse sistema. 


\section{Você sabia que os óleos e gorduras residuais de fritura têm valor agregado?}

\section{Sim, valem dinheiro!}

O titular dos serviços públicos de limpeza urbana, de acordo com a PNRS, deverá priorizar pessoas físicas de baixa renda para a organização de cooperativas de catadores de materiais reutilizáveis e recicláveis e catadores individuais.

Todo resíduo separado e acondicionado devidamente gera renda aos trabalhadores das cooperativas e aos individuais.

Conforme foi citado, a PNRS não dispõe sobre como separar os OGRF, mas os galpões de coleta seletiva recebem esses resíduos quando estiverem acondicionados em potes de plástico, de vidro e garrafas pet. 
Agora vou te contar uma coisa: Você sabia que os óleos e gorduras residuais de frituras também são materiais recicláveis?

Pois sim, eles são!

E quando você evita que esses OGRF cheguem ao meio ambiente, você estará praticando ALTERNATIVAS SUSTENTÁVEIS!

Os OGRF, depois de utilizados, se forem acondicionados corretamente, servirão de matéria-prima para a fabricação de novos produtos.

Com esse tipo de resíduo, è possível fabricar massa de vidraceiro, ração animal, glicerina, tinta, biocombustível e ainda gerar energia. Quantos produtos novos são possíveis de ser fabricados por meio dos OGRF! 


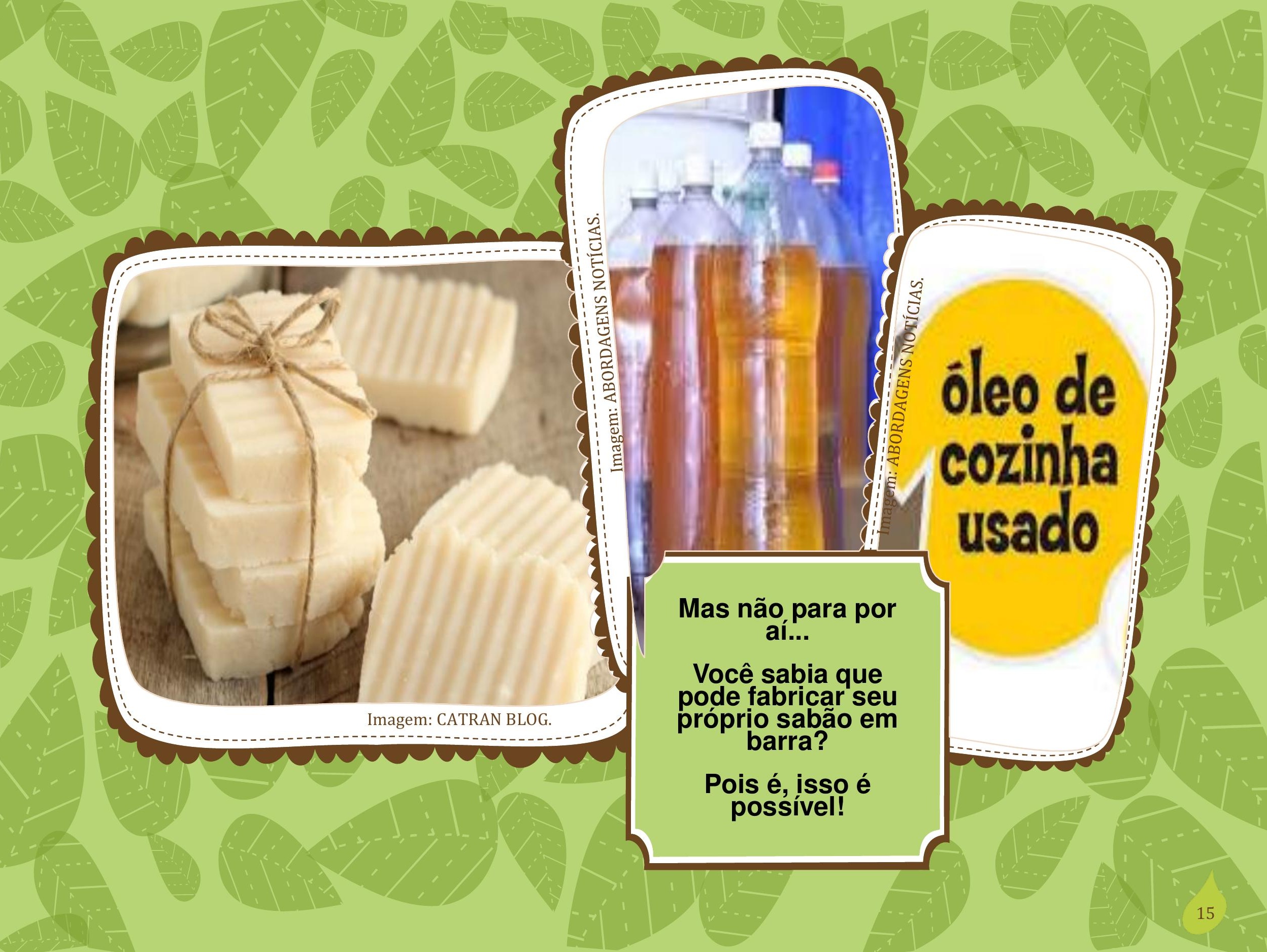


E quando você fabrica seu próprio sabão, utilizando os OGRF, novamente estará contribuindo para minimizar os impactos ambientais, além de economizar no supermercado.

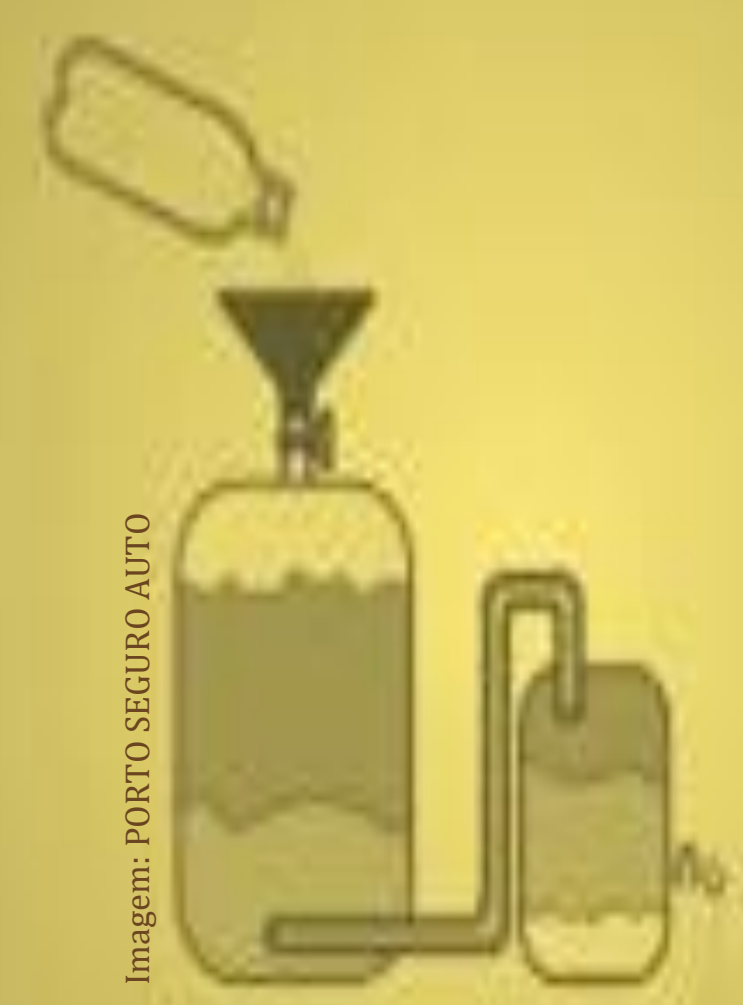

\section{Agora preste atenção!}

O sabão em barra, feito com OGRF, é chamado de sabão ecológico porque contribui para minimizar os impactos ambientais provocados pelo resíduo. 


\section{PARA FACILITAR, AQUI VAI A RECEITA DO SABÃO ECOLÓGICO EM BARRA!}

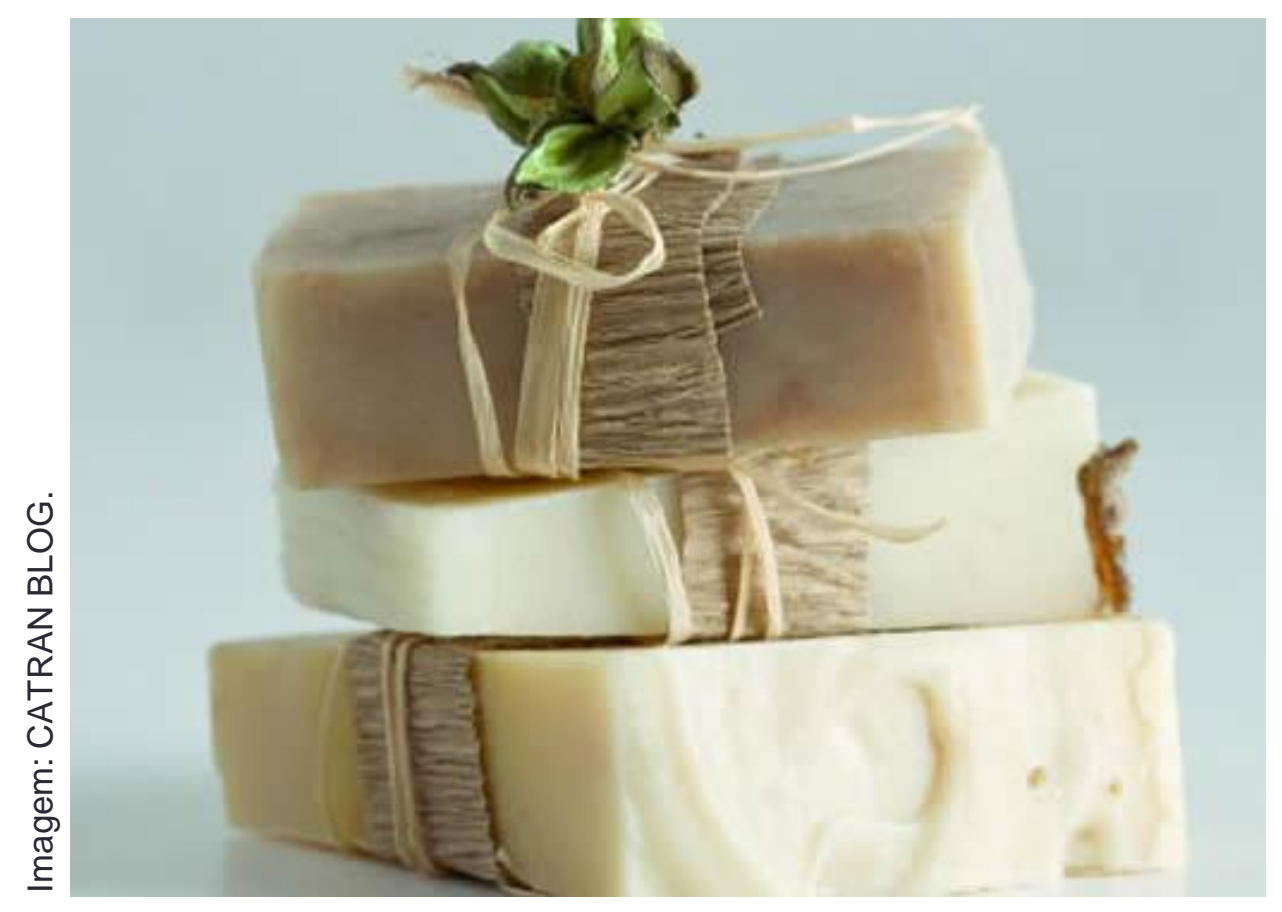

\section{INGREDIENTES:}

5 litros de óleo de cozinha (usado)

$1 \mathrm{~L}$ de água

$875 \mathrm{~g}$ de soda cáustica $(\mathrm{NaOH})$ em escama

$50 \mathrm{ml}$ de essência

$125 \mathrm{ml}$ de álcool

Caixa tipo tetra pak (para o molde)

Luvas

Máscara descartável

Coador ou peneira

1 balde

1 colher de plástico

Balança

\section{Modo de preparo:}

Antes de dar início ao preparo, é necessário paramentar-se com as luvas, máscaras e avental. Feito isso, dissolver a soda cáustica em água, misturando-a até que se dilua completamente. A seguir, adicionar os OGRF previamente coados, misturando-os aos demais ingredientes até que a mistura alcance o ponto de "leite condensado" (em torno de 30 ou 40 minutos). Após essas etapas, acrescentar a essência e misturar por mais 10 minutos. Depois, adicionar o álcool e misturar por mais 10 minutos e a mistura estará no ponto de descanso. Distribua a mistura em caixas de leite (tetra-pak $1 \mathrm{~L}$ ) e deixe descansar por 24 horas. Após o descanso, corte o sabão em barras e aguarde por mais 8 dias para que endureça por completo. 


\section{ENSINO DAS CIÊNCIAS AMBIENTAIS}

Você observou quantas coisas aprendeu sobre os óleos e gorduras residuais de fritura?

Que tal adentrar o espaço escolar e contribuir para a construção da consciência ecológica e fomentar boas práticas de responsabilidade social?

Vamos lá!

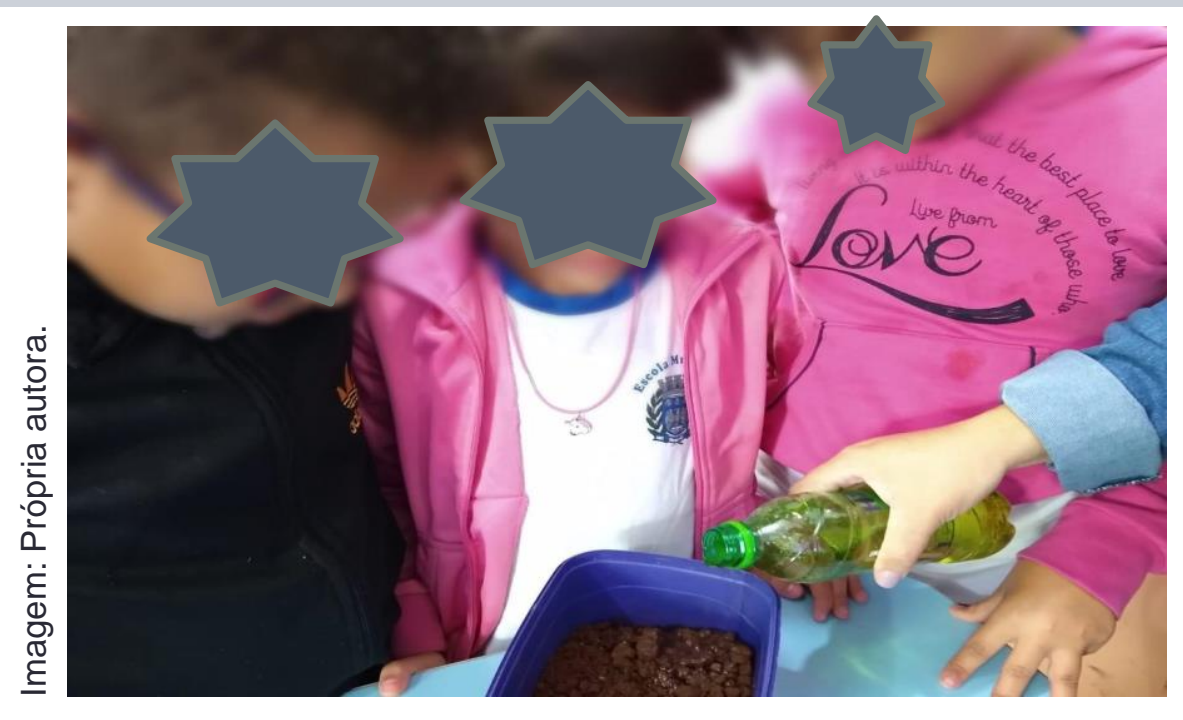

\section{Agora é com você, educador!}




\section{SEOUÉNCIA DIDÁTICA (SD)}

\section{E BASE NACIONAL COMUM CURRICULAR (BNCC)}

Você sabia que trabalhar com projetos que envolvam questões de ordem ambiental por meio de Sequência Didática favorece o processo de ensino- aprendizagem?

Pois bem, isso é comprovado!
A Sequência Didática constitui-se como um conjunto de atividades sistematizadas que pode ser trabalhada de maneira interdisciplinar e perpassar os vários componentes curriculares. (ZABALLA, 1998).

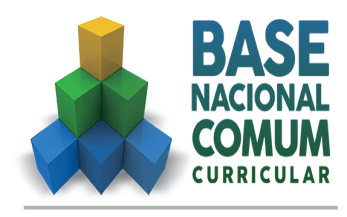

EDUCAÇÃO É A BASE

$\mathrm{Na}$ BNCC, os temas relacionados ao meio ambiente são tratados como Temas Contemporâneos Transversais (TCTs), e devem ser trabalhados sob a luz da interdisciplinaridade e transversalidade integrando os diferentes componentes curriculares. 


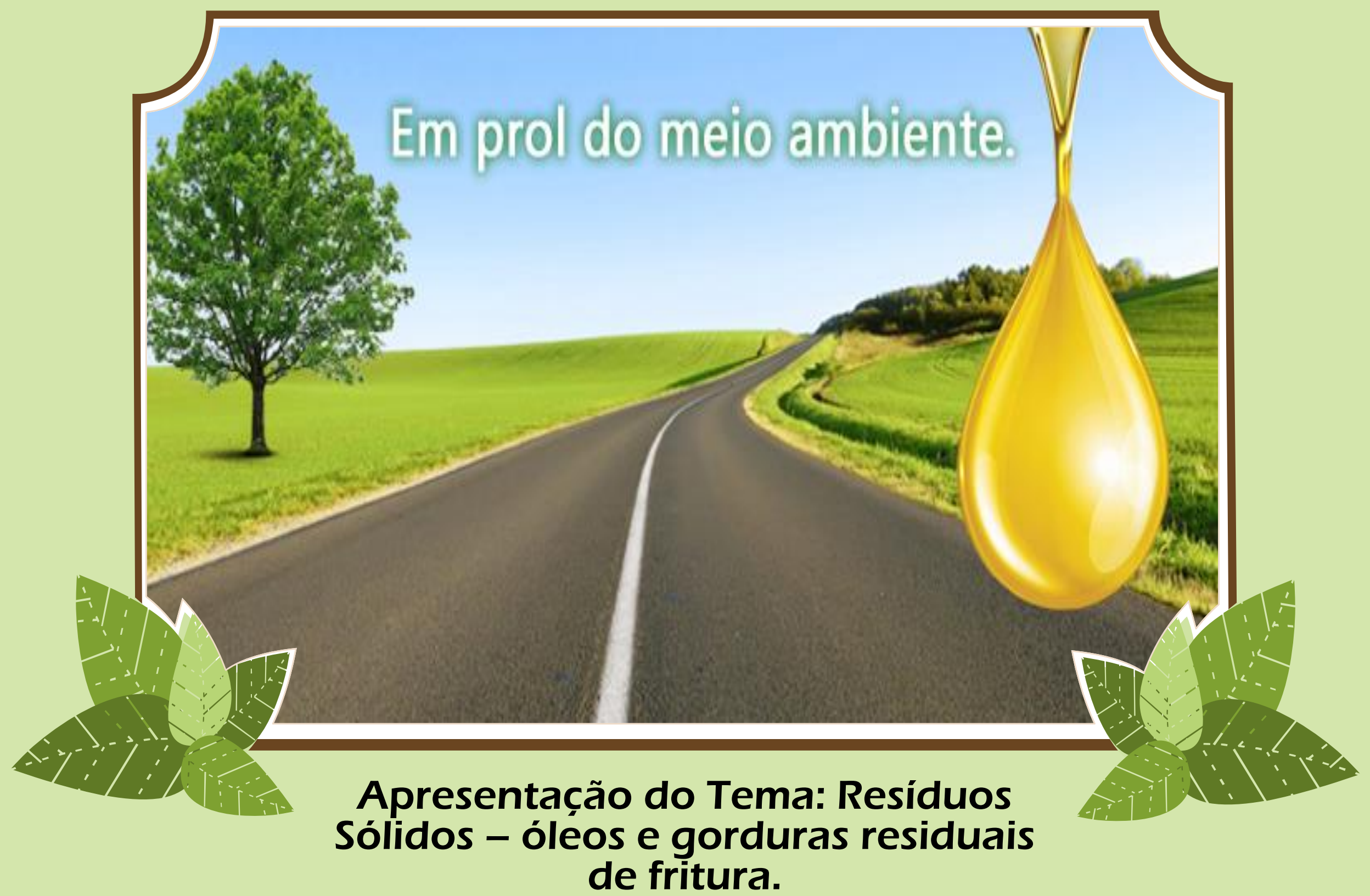




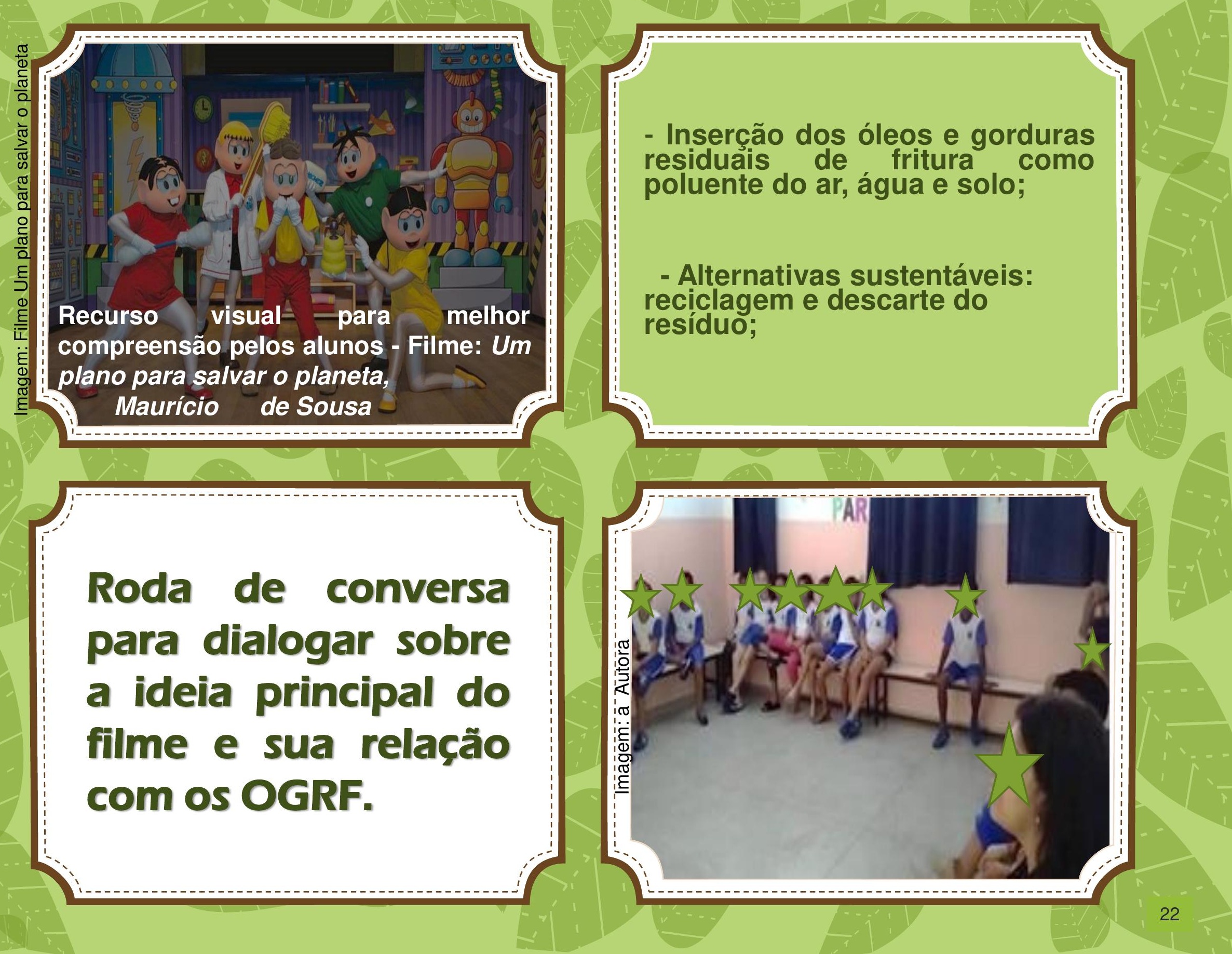




\section{Componente curricular: Língua Portuguesa}

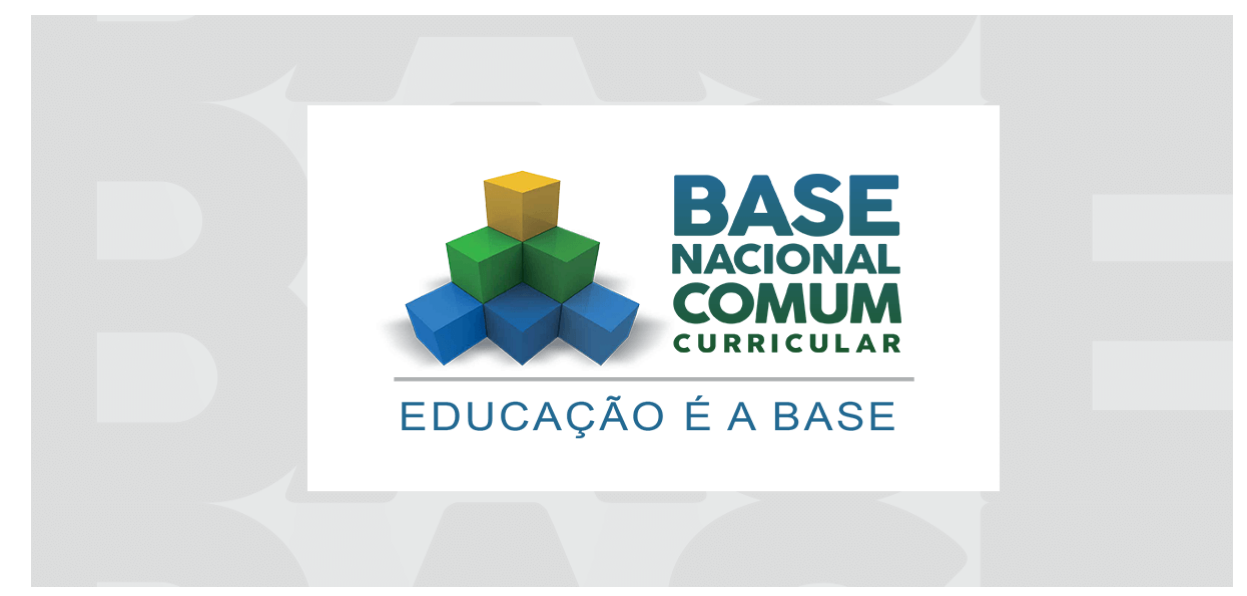

\section{Conteúdo:}

- Leitura e compreensão de texto;

- Escrita.

\section{Desenvolvimento :}

- Leitura compartilhada e escuta da música: Terra - Planeta água, de Guilherme Arantes;

- Identificação da ideia central da música;

- Produção de poesia sobre poluição ambiental: utilização de conceitos abordados desde a apresentação do Tema. 


\section{Componente curricular: Arte}

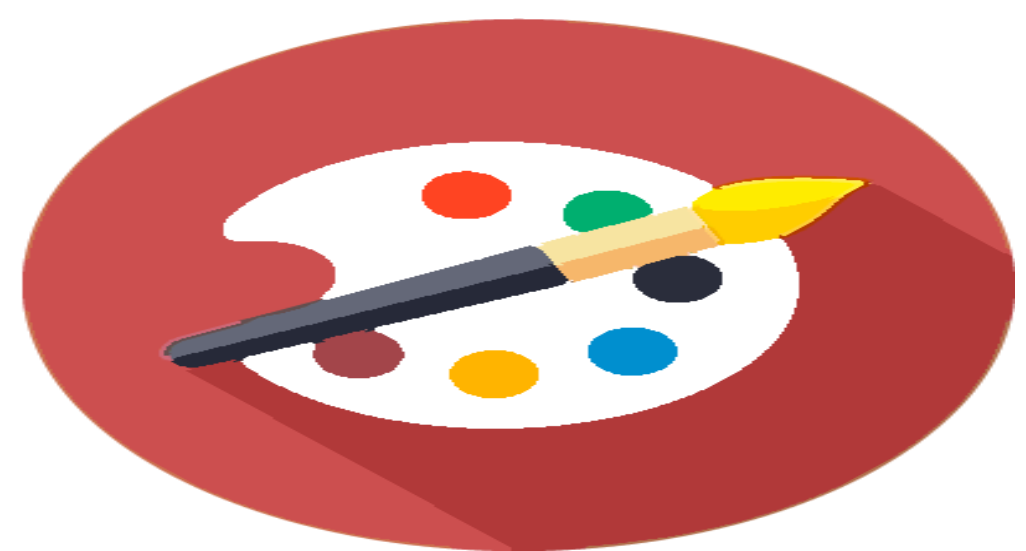

\section{Conteúdo:}

- Representação artística e movimentos.

\section{Desenvolvimento:}

- Música: Terra - Planeta água, de Guilherme Arantes;

- Representação da música por meio de desenho, valendo-se de tudo o que foi abordado durante todo o percurso da sequência didática;

- Representação da música por meio de dança coreografada ;

- Confecção de painel coletivo utilizando os desenhos produzidos. 


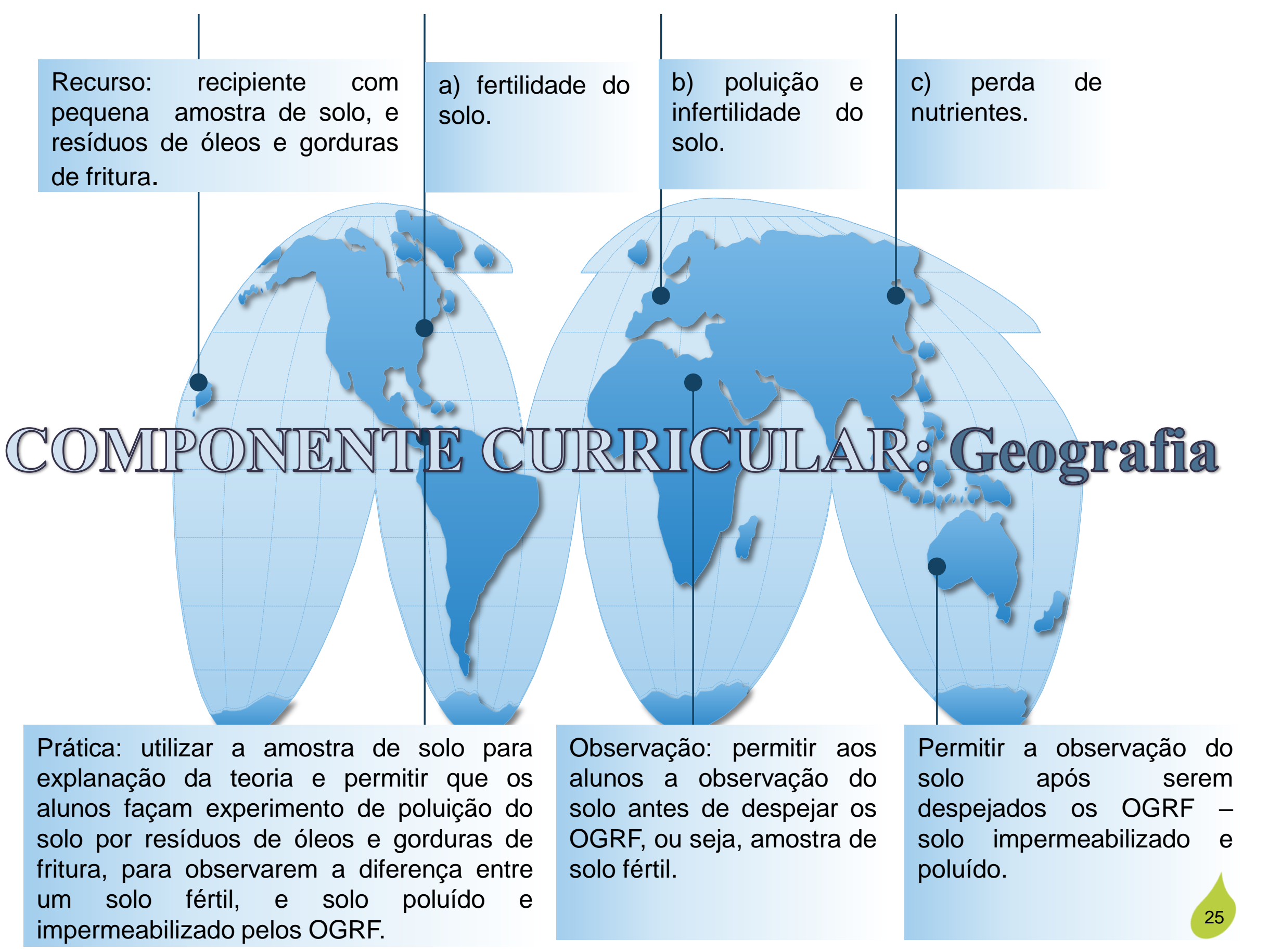




\section{Componente Curricular: Matemática}

\section{Conteúdos:}

- Grandezas e Medidas.

\section{Recurso:}

- O mesmo recipiente com amostra de solo utilizado na atividade de Geografia.

\section{Desenvolvimento:}

- Identificar a figura do recipiente;

- Contagem de lados e reflexão sobre igualdade e diferença dos lados do retângulo;

- Tipo de operação matemática para cálculo de área;

- Cálculo da área do recipiente. 


\section{INTEGRAÇÃO DOS PAIS E/OU RESPONSÁVEIS E COMUNIDADE}

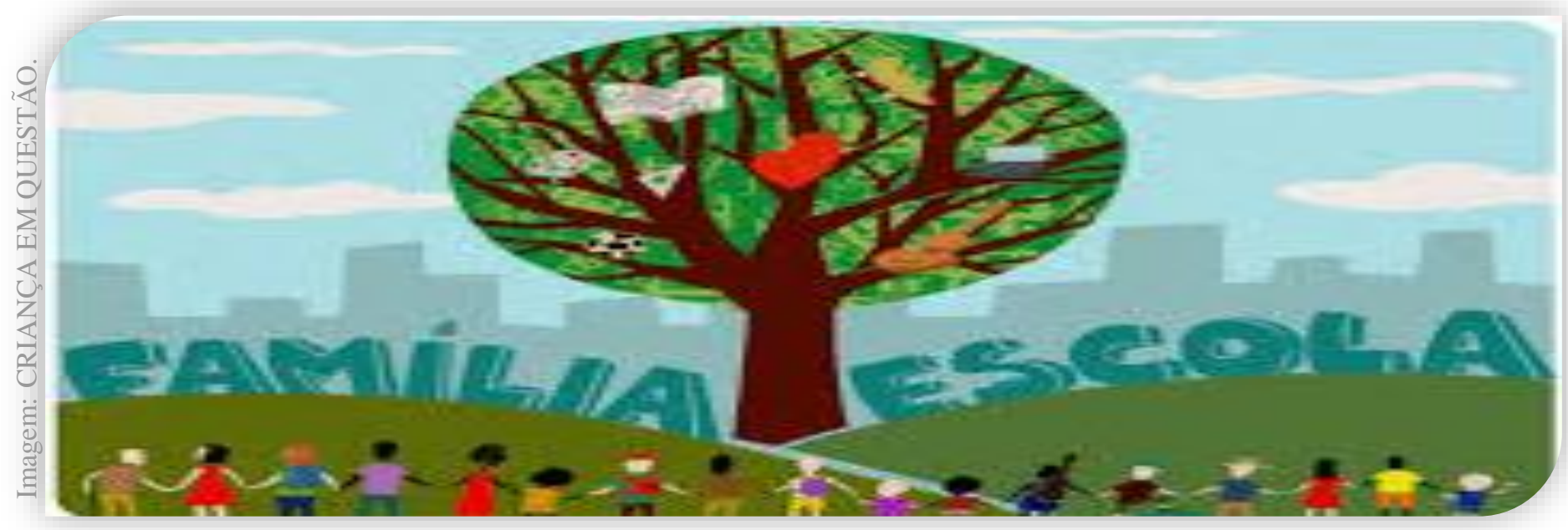

Os OGRF são resíduos sólidos domésticos, geralmente, manipulados pelos pais/ responsáveis...

Para integrá-los, foram realizados questionários e entrevistas para levantamento dos conhecimentos prévios acerca dos impactos ambientais provocados pelos OGRF e práticas adotadas no cotidiano.

A parceria entre família e escola é fundamental para o processo de ensinoaprendizagem e fortalecimento dos vínculos, já que a família é a primeira instância de aprendizagem. 


\section{Estratégias para integração dos pais e/ou responsáveis nos}

\section{processos educativos escolares}

- Aproveite a reunião de pais e/ou responsáveis para transmitir as informações constantes desta cartilha, relacionadas aos impactos ambientais provocados pelo descarte inadequado dos OGRF;

- Alternativas sustentáveis para os OGRF - reutilização, reciclagem e descarte adequado;

- Apresente as atividades desenvolvidas durante o projeto, convide os pais e/ou responsáveis para assistir à dança coreografada e visitar o painel coletivo de desenhos. Ofereça também um café para integração dos envolvidos.

\section{É isso! Agora faça sua parte!}




\section{SEJA CONSCIENTE: COLABORE COM O MEIO AMBIENTE!}

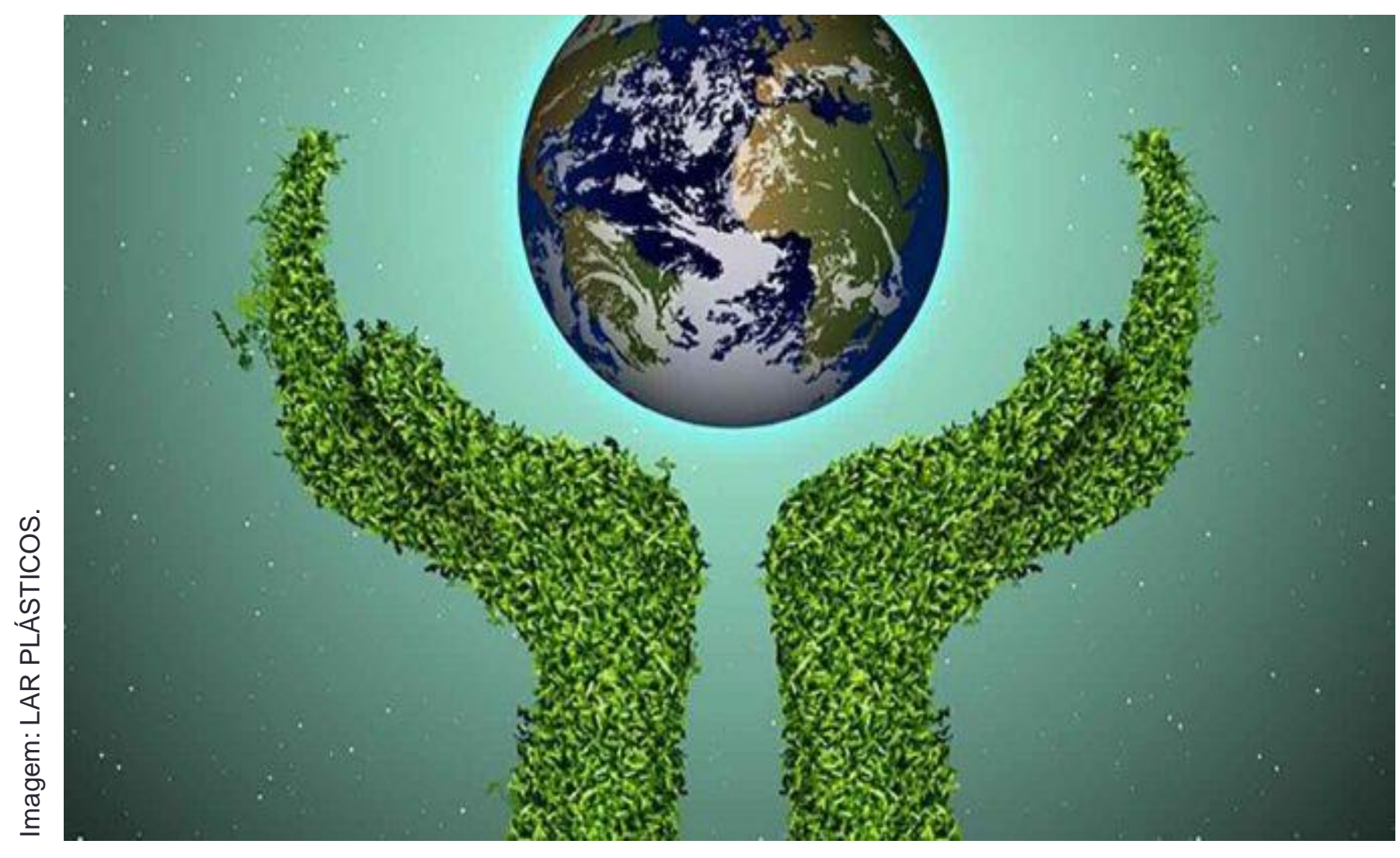




\section{REFERÊNCIAS}

BRASIL. Lei № 12.305, de 2 de agosto de 2010. Política Nacional de Resíduos Sólidos, Brasília-D.F, ago. 2010. Disponível em: http://www.planalto.gov.br/ccivil 03/ ato2007-2010/2010/lei//12305.htm. Acesso em: 21 maio 2019.

BRASIL. Base Nacional Comum Curricular. Educação é Base. Brasília-D.F, 2017. Disponível em:

http://basenacionalcomum.mec.gov.br/images/BNCC EI EF 110518 versaofinal site.pdf . Acesso em 20 dez. 2019.

CETESB. Aterros sanitários, aterros controlados e lixões: entenda o destino do lixo no Paraná. Disponível em: https://cetesb.sp.gov.br/biogas/2017/08/01/aterros-sanitarios-aterros-controlados-e-lixoes-entenda-o-destino-do-lixo-noparana/. Acesso em: 10 dez. 2019.

LIMA, N. M. O.; et al. Produção e caracterização de sabão ecológico - uma alternativa para o desenvolvimento sustentável do semiárido paraibano. Revista Saúde e Ciência On-line, 2014, v. 3, n. 3, p. 26-36, set-dez, 2014. Disponível em:

http://www.ufcg.edu.br/revistasaudeeciencia/index.php/RSC-UFCG/article/viewFile/171/108. Acesso em: 10 dez. 2019.

PONT, B. Escola deve dar a pais ideia clara sobre o que se espera deles. São Paulo, 2012. Disponível em:

https://oglobo.globo.com/sociedade/educacao/beatriz-pont-escola-deve-dar-pais-ideia-clara-sobre-que-se-espera-deles-670018 . Acesso em: 22 maio 2019.

TERRA, PLANETA ÁGUA. Intérprete: Guilherme Arantes. Compositor: Guilherme Arantes. In: Intimidade. São Paulo: RCA Victor, 2007. 1 CD, faixa 1 (5’53").

TURMA DA MÔNICA: um plano para salvar o planeta Terra. Gabriel Penna. 2013. Disponível em: https://www.youtube.com/watch?v=dCOOWSbe6lg\&t=27s. Acesso em: 20 fev. 2020.

ZABALA, A. A prática educativa: como ensinar. Porto Alegre: ARTMED, 1998.

ZUCATTO, L. C.; WELLE, I.; SILVA, T. N. Da Cadeia reversa do óleo de cozinha: coordenação, estrutura e aspectos relacionais. RAE-Revista de Administração de Empresas, v. 53, n. 5, setembro-outubro, p.539-550, 2013. Disponível em:

http://www.scielo.br/scielo.php?pid=S0034-5902013000500003\&script=sci_abstract\&tlng=pt. Acesso em 12 dez. 2019. 


\section{REFERÊNCIAS DAS IMAGENS}

ABORDAGENS NOTÍCIAS. Nesta quarta-feira tem troca do óleo de cozinha usado por novo em Paraguaçu. 2019.

https://www.google.com/imgres?imgurl=https\%3A\%2F\%2Fwww.abordagemnoticias.com\%2Fuploads\%2Fnoticias\%2F649192611201 9095006.jpg\&imgrefurl=https\%3A\%2F\%2Fwww.abordagemnoticias.com\%2Fnoticia\%2F4843\%2Fnesta-quarta-feira-tem-troca-dooleo-de-cozinha-usado-por-novo-em-

paraguacu\&tbnid=YBfOcPRF TOcEM\&vet=10CHEQMyicAWoXChMliKnEk9f 5wIVAAAAABOAAAAAEAl..i\&docid=sJcxWyLVKual M $\& \mathrm{w}=640 \& \mathrm{~h}=454 \& \mathrm{q}=\% \mathrm{C} 3 \%$ B3leo\%20de\%20cozinha\&ved=0CHEQMyicAWoXChMliKnEk9f 5wIVAAAAAB0AAAAAEAl. Acesso em: 04 maio 2020 .

BIORIB. Por que a reciclagem do óleo de cozinha é importante? Disponível em: https://biorib.com.br/site/por-que-a-reciclagemdo-oleo-de-cozinha-e-importante/. Acesso em: 02 maio 2020.

CATRAN BLOG. Aprenda a fazer sabão com óleo de cozinha usado. 2017. Disponível em:

https://catranblog.com/2016/10/07/aprenda-a-fazer-sabao-com-oleo-de-cozinha-usado/. Acesso em: 03 maio 2020.

CRIANÇA EM QUESTÃO. Família, criança e escola: Um trio afinado a favor da inclusão. Disponível em: http://www.criancaemquestao.com.br/2016/05/familia-crianca-e-escola-um-trio.html. Acesso em: 10 ago. 2020.

FREEPIK. Disponível em: ttps://br.freepik.com/fotos-gratis/crianca-escrevendo-letras-no-bloco-de-notas 1343967.htm. Acesso em: 10 ago. 2020.

LAR PLÁSTICOS. Preservar o meio ambiente: responsabilidade de todos! 2020. Disponível em: https://www.larplasticos.com.br/ultimas-noticias/preservar-o-meio-ambiente-responsabilidade-de-todos. Acesso em: 10 ago. 2020.

PORTO SEGURO AUTO. Programa de reciclagem de óleo de cozinha. 2016. (02'15"). Disponível em: https://www.youtube.com/watch?v=M0Aspk5FrLI. Acesso em: 04/05/2020.

SABESP. Óleo e água não se misturam: a solução é reciclar. Disponível em: http://site.sabesp.com.br/site/interna/Default.aspx?secaold=82. Acesso em: 02 maio 2020. 


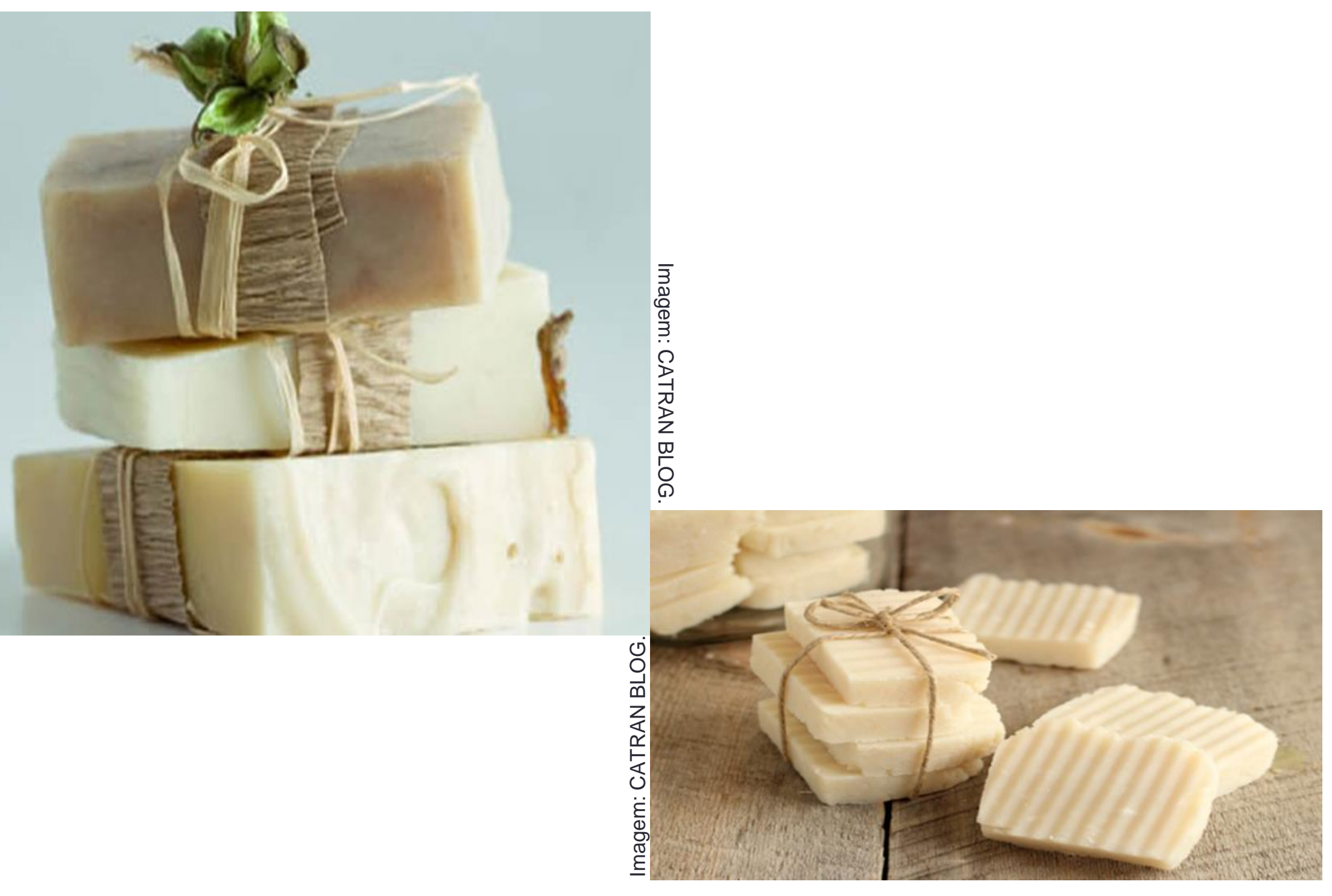




\section{APÊNDICE B: QUESTIONÁRIO PARA LEVANTAMENTO DE DADOS SOBRE O USO E DESCARTE DOS ÓLEOS RESIDUAIS DE COZINHA}

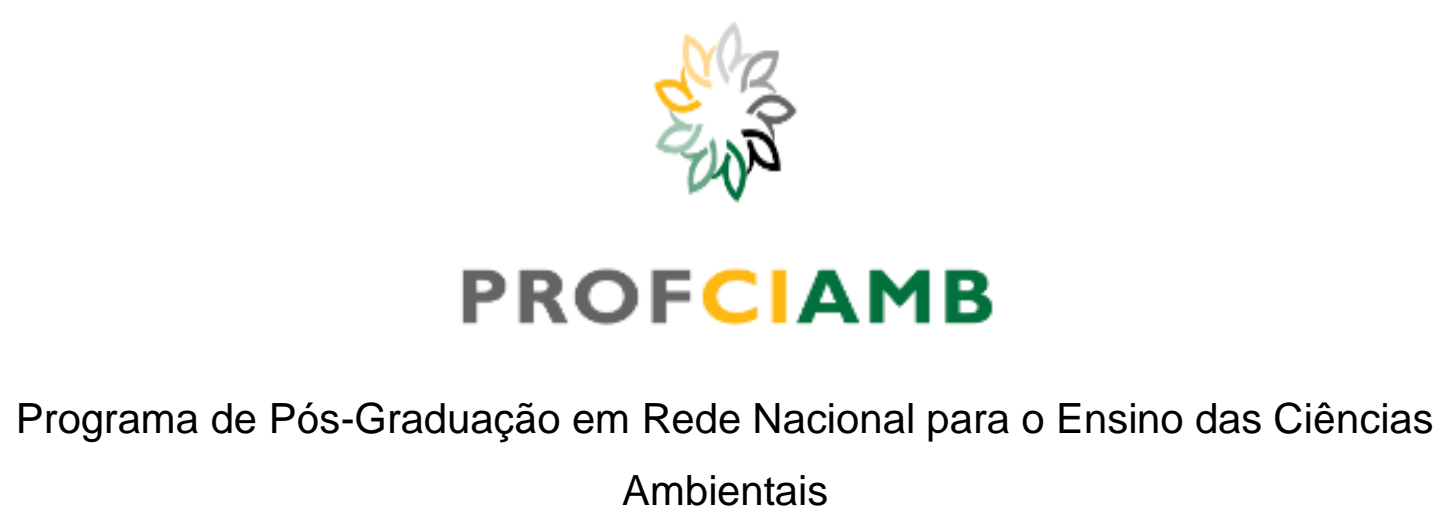

Prezado participante,

Este questionário constitui-se num instrumento de coletas para levantamento de dados sobre o uso e descarte dos óleos e gorduras residuais de fritura utilizados em seu domicílio. O objetivo deste instrumento é contribuir para a pesquisa da Mestranda Carla Cristina Castanheiro dos Santos, sob a orientação do Prof. Dr. Tadeu Fabrício Malheiros, realizada no Programa de Pós-Graduação em Rede Nacional para o Ensino das Ciências Ambientais da Universidade de São Paulo.

Idade do respondente:

1 - Quantas pessoas moram na sua casa?

2 - Qual tipo de óleo de origem animal ou vegetal é utilizado na sua residência?

3 - Qual a quantidade de óleo ou gordura (uso culinário) que sua família consome por mês?

4 - Após o uso do óleo, qual é a prática adotada, em sua casa, em relação ao descarte? 


\section{ANEXO A - MÚSICA PLANETA ÁGUA}

\section{Planeta Água}

Água que nasce na fonte serena do mundo

E que abre um profundo grotão

Água que faz inocente riacho

E deságua na corrente do ribeirão.

Águas escuras dos rios

Que levam a fertilidade ao sertão

Águas que banham aldeias

E matam a sede da população.

Águas que caem das pedras

No véu das cascatas, ronco de trovão

E depois dormem tranquilas

No leito dos lagos

No leito dos lagos.

Água dos igarapés

Onde lara, a mãe d'água

É misteriosa canção

Água que o sol evapora

Pro céu vai embora

Virar nuvens de algodão.

Gotas de água da chuva

Alegre arco-íris sobre a plantação

Gotas de água da chuva

Tão tristes, são lágrimas na inundação. 
Águas que movem moinhos

São as mesmas águas que encharcam o chão

E sempre voltam humildes

Pro fundo da terra

Pro fundo da terra.

Terra! Planeta Água

Terra! Planeta Água

Terra! Planeta Água

Água que nasce na fonte serena do mundo

E que abre um profundo grotão

Água que faz inocente riacho

E deságua na corrente do ribeirão.

Águas escuras dos rios

Que levam a fertilidade ao sertão

Águas que banham aldeias

E matam a sede da população.

Águas que movem moinhos

São as mesmas águas que encharcam o chão

E sempre voltam humildes

Pro fundo da terra

Pro fundo da terra.

Terra! Planeta Água

Terra! Planeta Água

Terra! Planeta Água

Terra! Planeta Água

Terra! Planeta Água

Terra! Planeta Água

(Compositor e intérprete: Guilherme Arantes) 